University of Louisville

ThinkIR: The University of Louisville's Institutional Repository

$5-2012$

\title{
Click scaffolds for the inhibition of Porphyromonas gingivalis and Streptococcus gordonii biofilm formation.
}

Catherine Marie Loner

University of Louisville

Follow this and additional works at: https://ir.library.louisville.edu/etd

\section{Recommended Citation}

Loner, Catherine Marie, "Click scaffolds for the inhibition of Porphyromonas gingivalis and Streptococcus gordonii biofilm formation." (2012). Electronic Theses and Dissertations. Paper 853.

https://doi.org/10.18297/etd/853

This Master's Thesis is brought to you for free and open access by ThinkIR: The University of Louisville's Institutional Repository. It has been accepted for inclusion in Electronic Theses and Dissertations by an authorized administrator of ThinkIR: The University of Louisville's Institutional Repository. This title appears here courtesy of the author, who has retained all other copyrights. For more information, please contact thinkir@louisville.edu. 
CLICK SCAFFOLDS FOR THE INHIBITION OF PORPHYROMONAS GINGIVALIS AND STREPTOCOCCUS GORDONII BIOFILM FORMATION

By

Catherine Marie Loner

B.A. University of Notre Dame, 2010

\begin{abstract}
A Thesis
Submitted to the Faculty of the University of Louisville Dental School In Partial Fulfillment of the Requirements

For the Degree of
\end{abstract}

Master of Science

Department of Oral Biology

University of Louisville

Louisville, Kentucky

May 2012 
CLICK SCAFFOLDS FOR THE INHIBITION OF PORPHYROMONAS GINGIVALIS AND STREPTOCOCCUS GORDONII BIOFILM FORMATION

By

Catherine Marie Loner

B.A. University of Notre Dame, 2010

Thesis Approved on

April 18, 2012

By the following Thesis Committee:

Donald Demuth, Thesis Director

Frederick Luzzio 


\begin{abstract}
CLICK SCAFFOLDS FOR THE INHIBITION OF PORPHYROMONAS GINGIVALIS
\end{abstract}

AND STREPTOCOCCUS GORDONII BIOFILM FORMATION

Catherine M. Loner

April 18, 2012

Periodontitis and its systemic sequelae remain a major public health problem and developing a cost-efficient therapy will benefit healthcare worldwide. Adherence of Porphyromonas gingivalis to Streptococcus gordonii facilitates colonization of the oral cavity by $P$. gingivalis and contributes to development of periodontal disease. It has been demonstrated that synthetic peptides (BAR-peptides) inhibit this interaction and the formation of $P$. gingivalis biofilms. However, peptides are susceptible to proteolytic degradation thereby precluding their use as therapeutic agents. Consequently, rationallydesigned small-molecule peptidomimetics of BAR will potently inhibit $P$. gingivalis adherence to $S$. gordonii and represent viable therapeutic compounds. In terms of inhibitor design, a small molecule "click" strategy was employed whereby the azidebearing partner constitutes a trisubstituted oxazole framework and the terminal acetylene partner constitutes a 5-ethynylmethylene-1,3-diaminotriazine framework. The design, synthesis and chemistry of the coupling partners in both the acetylenic and azido series have been developed, and the use of these compounds as therapeutic agents is discussed. 


\section{ACKNOWLEDGEMENTS}

I would like to thank Dr. Donald Demuth for inviting me into his lab, and giving me the opportunity to work on this project. I too would like to thank him for his constant guidance and encouragement throughout these two years. I would also like to thank Dr. Frederick Luzzio for his continued support, advice and patience day in and day out.

Additionally, I am grateful for the financial support provided by Dr. Donald Demuth's RIF funds from the University of Louisville. 


\section{DEDICATION}

This thesis is dedicated to my loving parents, Lawrence and Christy Loner, who have given me everything I could possibly need to accomplish my goals, and encouraging me every step of the way. I am and will forever be grateful to have them as my parents. I also would like to dedicate this thesis to the greatest siblings, Michael and Caroline

Loner, who, like my parents, have loved and supported me throughout this process in spite of all of my senseless behavior. 
TABLE OF CONTENTS

PAGE

$\begin{array}{lr}\text { ABSTRACT } & \text { iii } \\ \text { ACKNOWLEDGEMENTS } & \text { iv } \\ \text { DEDICATION } & \text { v } \\ \text { LIST OF FIGURES } & \text { viii } \\ \text { LIST OF SCHEMES } & 1 \\ \text { INTRODUCTION } & 10 \\ \text { SCHEMES } & 13 \\ \text { RESULTS } & 17 \\ \text { METHODS } & \\ \text { DISCUSSION } & 29 \\ \text { REFERENCES } & 32 \\ \text { APPENDIC (I) ABBREVIATIONS } & 35 \\ \text { APPENDIX (II) SPECTRA } & 36 \\ \text { CURRICULUM VITAE } & 71\end{array}$ 


\section{LIST OF SCHEMES}

PAGE

$\begin{array}{ll}\text { Scheme 1 } & 10\end{array}$

$\begin{array}{ll}\text { Scheme } 2 & 10\end{array}$

$\begin{array}{ll}\text { Scheme } 3 & 11\end{array}$

$\begin{array}{ll}\text { Scheme } 4 & 11\end{array}$

$\begin{array}{ll}\text { Scheme } 5 & 11\end{array}$

$\begin{array}{ll}\text { Scheme } 6 & 12\end{array}$

$\begin{array}{ll}\text { Scheme } 7 & 12\end{array}$

$\begin{array}{ll}\text { Scheme } 8 & 12\end{array}$ 


\section{INTRODUCTION}

\section{Significance of Periodontal Diseases}

Periodontal disease is one of the most common bacterial infections in humans. The World Health Organization estimates that severe periodontitis, defined as having subgingival pocket depths of greater than or equal to $6 \mathrm{~mm}$, occurs in $5-20 \%$ of adults worldwid $^{1}$ When individuals with milder forms of the disease (i.e. pocket depths of 4-5 $\mathrm{mm}$ ) are included, the prevalence of periodontitis increases to approximately $35-50 \%$ of the adult population ${ }^{1}$. In the United States alone, the annual expenditure for the treatment of periodontal diseases is in the billions of dollars ${ }^{2}$. Not only is periodontitis alone a prevalent health issue, but it has also been linked to other systemic illnesses such as respiratory diseases, adverse pregnancy outcomes, chronic renal disease, oral cancer, Inflammatory Bowel Disease, and Alzheimer Disease ${ }^{3}$. The most common treatment for periodontal diseases is scaling and root planing, which is the clinical removal of soft and hardened subgingival biofilms from exposed root surfaces with the use of specific dentistry tools ${ }^{4}$. The other commonly used therapy is periodontal surgery. The benefits of periodontal surgery over scaling and root planing is that surgery allows for better access for cleaning of the root surfaces, pocket reduction (or elimination) and exposure of root surfaces for proper cleaning by the patients ${ }^{4}$. These therapeutic approaches are efficient for removing the bacteria, however these approaches do not specifically target periodontal pathogens nor do they prevent or limit re-colonization of the oral cavity by these pathogens after removal. Therefore, the initial colonization mechanisms utilized by 
$P$. gingivalis are analyzed in this study and are viewed as important targets for the development of therapeutic agents. As discussed below, interfering with $P$. gingivalis adherence to $S$. gordonii may block initial colonization of the supragingival biofilm by the organism and prevent it from reaching and multiplying in its primary niche in the subgingival plaque.

\section{Periodontal Diseases: Significance of the P. gingivalis-S. gordonii interaction}

The bacterial etiology of periodontal disease is complex, and a variety of organisms have been associated with the initiation and progression of the disease. Many, if not all, of these organisms may also be present in healthy individuals, albeit at lower levels than in the disease state, and can exist in mutual harmony with the host. Thus, disease episodes develop from a shift in the ecological balance between bacterial and host factors. For example, alteration in the absolute or relative numbers of certain organisms, or alteration of particular host factors could shift the ecological balance towards disease $\mathrm{e}^{5}$.

In general, severe forms of the disease in adults are associated with a limited number of gram-negative anaerobic bacteria. Within this group, evidence points to a pathogenic role for $P$. gingivalis, and the presence of this organism appears to be essential for disease activity. In addition, the results of a study completed by Hajishengallis et. al. ${ }^{6}$ showed that the presence of $P$. gingivalis in the oral cavity, even at low levels, caused significant changes in the oral biofilm that were associated with inflammation and ultimately, the resorption of alveolar bone. Specifically, this study demonstrated that the introduction of $P$. gingivalis into specific-pathogen-free mice led to the elevation of commensal bacterial popoulations and also changed the composition of the murine oral microbiota. Importantly, as determined by real-time PCR, $P$. gingivalis 
represented $<0.01 \%$ of the total bacteria count in the biofilm ${ }^{6}$. Even at such a low levels, $P$. gingivalis caused significant disruption of host-microbe homeostasis resulting in a shift from a non-pathogenic to a pathogenic community ${ }^{6}$. Thus, if the initial attachment of $P$. gingivalis to the oral tissue surfaces or to antecedent bacteria can be prevented, it may be possible to control $P$. gingivalis populations and maintain host-microbe homeostasis ${ }^{5}$.

The oral cavity provides a variety of surfaces like the mineralized hard tissues of the teeth, the mucosal surfaces of the gums, the cheek, and the tongue to which $P$. gingivalis can adhere. Colonization of surfaces remote from the gingival crevice and periodontal pocket can still have significance for the disease process because once established, $P$. gingivalis may reach the subgingival area by spreading proliferation or by the movement of detached bacteria into the area ${ }^{5}$. Oral surfaces generally are coated with a pellicle composed predominantly of salivary molecules. It is components of these pellicles that function as receptors for primary colonizer bacterial adherence. The oral surfaces rapidly become colonized with the early commensal microbiota of the mouth, as a consequence, organisms such as $P$. gingivalis usually encounter surfaces rich in antecedent bacteria and their products ${ }^{5}$. P. gingivalis can adhere to many of these early plaque organisms such as oral streptococci, specifically S. gordonii, and use their metabolic products as nutrients for growth and proliferation.

$P$. gingivalis contains two types of fimbriae and other outer membrane proteins which allow it to bind to bacterial substrates in the oral cavity ${ }^{7}$. Specifically, the adhesion of $P$. gingivalis and $S$. gordonii is multimodal and involves at least two distinct receptor-ligand pairs. The long and short fimbriae of $P$. gingivalis have both been shown 
to be involved in this interaction ${ }^{8}$. The structural subunit of the long fimbriae, FimA, has been shown to interact with cell surface glyceraldehyde-3-phosphate dehydrogenase (Gap-DH) of S. gordonii ${ }^{9,10}$, whereas the minor fimbrial protein, Mfal, interacts with streptococcal SspB ${ }^{11}$, a cell surface protein in the antigen $\mathrm{I} / \mathrm{II}$ family that is expressed by virtually all of the oral streptococci ${ }^{12}$. Interestingly, although virtually all of the oral streptococci express antigen $\mathrm{I} / \mathrm{II}, P$. gingivalis selectively adheres to $S$. gordonii and the related oralis group of streptococci ${ }^{7}$. This suggests that $P$. gingivalis selectively colonizes $S$. gordonii and the related oralis streptococci over the mutans streptococci. In addition, Demuth et. al. ${ }^{13}$ and Cook et. al. ${ }^{14}$ showed that the Mfa1-SspB interaction is essential for the development of $P$. gingivalis biofilms on a streptococcal substrate and that biofilm growth exhibits the same selectivity for streptococcal species.

\section{Important Findings in Previous Studies}

As discussed above, two fimbrial proteins of $P$. gingivalis (FimA and Mfa1) interact with specific receptors of $S$. gordonii (GapDH and SspB) and the Mfa1-SspB interaction is essential for the adherence of intact $P$. gingivalis to streptococcal cells and

the subsequent development of $P$. gingivalis biofilms ${ }^{13,14}$. Structure-function analyses on the mechanism of Mfal-SspB interaction identified a discrete region of $\mathrm{SspB}$, designated BAR (SspB Adherence Region) that was essential for the association of $P$. gingivalis cells with $S$. gordonii. Daep et. al. ${ }^{7}$ showed that a synthetic peptide encompassing the active site region of $\mathrm{SspB}$ is a potent inhibitor $(50 \%$ inhibitory at a concentration of 1.3 $\mu \mathrm{M}$ ) of $P$. gingivalis adherence to $S$. gordonii cells and blocks the formation of $P$. gingivalis biofilms ${ }^{7}$. This peptide is also capable of disrupting existing $P$. gingivalis biofilms (D.R. Demuth, unpublished). Two structural motifs in BAR, NITVK and 
$\mathrm{KKVQDLLKK}^{7,15}$ were shown to be the active motifs contributing to $P$. gingivalis adherence. When each of these amino acid sequences separately was tested for inhibitory activity, they were inactive, which confirmed that the interaction of BAR with $P$. gingivalis requires both the KKVQDLLKK and NITVK motifs ${ }^{15}$.

Several structure and functional analyses have been done on the BAR peptide that have given many insights into the characteristics that make the $S$. gordonii- $P$. gingivalis interaction unique. In a study by Daep et. al. ${ }^{7}$ the amino acids $\mathrm{Asn}^{1182}$, $\mathrm{Thr}^{1184}$, and $\mathrm{Val}^{1185}$ of the NITVK sequence were replaced with each of the other 19 common amino acids, and the resulting substituted peptides were tested to determine their inhibitory activity. This study showed that peptides containing positively charged amino acids replacing $\mathrm{Asn}^{1182}$ or bulky hydrophobic residues replacing $\mathrm{Val}^{1185}$ increased the binding of $P$. gingivalis to the BAR peptide. These positive replacements suggest that both electrostatic and hydrophobic interactions are important for Mfal-SspB binding ${ }^{7}$. It was also shown that replacement of $\mathrm{Asn}^{1182}$ or $\mathrm{Val}^{1185}$ with Pro or Gly residues decreased the interaction between $P$. gingivalis and BAR. Since these amino acids are helix disrupting, this result suggested that the secondary structure of BAR is also important for activity ${ }^{7}$. A subsequent study by Daep et. al. ${ }^{15}$ showed that the second active motif, KKVQDLLKK, along with the NITVK motif have characteristics that are similar to the eukaryotic nuclear receptor box protein-protein interaction domain ${ }^{15}$. The nuclearreceptor box is a short, hydrophobic, alpha-helical motif in eukaryotic co-activator proteins (consensus LXXLL) that is essential for their interaction with the cognate nuclear receptor ${ }^{16}$. This interaction is stabilized by hydrogen bonding and/or chargecharge interactions of amino acids flanking $\mathrm{LXXLL}^{17}$ with the ligand-binding domain of 
the nuclear receptor ${ }^{16}$. To determine if VXXLL in BAR functioned similarly to the nuclear-receptor box, Daep et. al. ${ }^{15}$ examined the contribution of the alpha-helical content, the hydrophobic character of VXXLL, and the contribution of charged amino acids flanking VXXLL to the interaction of BAR with $P$. gingivalis. The alpha-helical content and the presence of basic residues were shown to play a greater role in the association of BAR with $P$. gingivalis than did the hydrophobic character of the VXXLL alpha-helix, although this characteristic was still necessary for the interaction ${ }^{15}$.

\section{Why BAR peptide mimetics?}

The development of the BAR peptide and the modified BAR peptides that increase its inhibitory activity is a great advancement and forms the foundation to develop potential targeted therapies to limit $P$. gingivalis infections. However, the use of peptides as therapeutics has limitations arising from the high cost of peptide synthesis and their susceptibility to proteases expressed by oral organisms, including $P$. gingivalis itself. The challenge is to produce a potent and stable inhibitor that is not based on a peptide backbone but mimics the natural peptide substrate recognized by Mfal. The aforementioned studies that have defined the physiochemical properties important in the Mfal-SspB interaction are important, and show specific characteristics that any developed chemical substrate should mimic in order to be a potent inhibitor.

\section{Role of Synthetic Click Chemistry}

One traditional alternative approach to identify a non-peptide based inhibitor of the Mfa-SspB interaction involves the synthesis and screening of large numbers of compounds to isolate the few functional inhibitors that the initial compound library may contain. However, this approach also has limitations since it is both costly and time 
consuming. To overcome these limitations, we proposed to utilize a novel organic synthesis approach called in situ click chemistry to design and synthesize non-peptide based inhibitors of the Mfa1-SspB interaction, using the structural and biochemical information of the Mfa1-SspB interaction derived from previous work as a foundation.

Click chemistry is a chemical philosophy introduced by K. Barry Sharpless in 1999. Click chemistry is not a specific reaction, but a concept that mimics nature. It is chemistry tailored to generate substances quickly and reliably by joining small units together whereby the product may have greater activity than the individual fragments. This joining is inspired by the fact that nature also generates substances by combining smaller units together ${ }^{18}$. For example, proteins are made from repeating amino acid units and sugars are made from repeating monosaccharide units. The connecting units in click chemistry are based on carbon-hetero atom bonds $(\mathrm{C}-\mathrm{X}-\mathrm{C})$ rather than $\mathrm{C}-\mathrm{C}$ bonds ${ }^{18}$. Sharpless and his group have defined a set of guidelines for a reaction to be considered click chemistry. "The reactions must be modular, wide in scope, give very high yields, generate only inoffensive byproducts that can be removed by non-chromatographic methods, and be stereo-specific. The required process characteristics include simple reaction conditions, readily available starting materials and reagents, solvent-less conditions or a solvent that is benign or easily removed, and simple product isolation ${ }^{18}$." Furthermore, the reactions need to have a high thermodynamic driving force, greater than $20 \mathrm{kcal} / \mathrm{mol}$ is preferable. Having this high thermodynamic driving force will lead to a reaction that is quick, and selective for a single product ${ }^{18}$.

In this particular study, we have utilized the most common click chemistry reaction, the Huisgen 1,3-dipolar cycloaddition of azides and terminal alkynes to form 
1,2,3-triazoles[19]. Azides and acetylenes are highly energetic functional groups and the 1,2,3-triazole formation from these two functional groups is a particularly powerful linking reaction due to its high degree of dependability and complete specificity. The following is an example of the simplest metal catalyzed mechanism for the cycloaddition of azides and terminal alkynes to form triazoles (Figure 1) ${ }^{19}$.

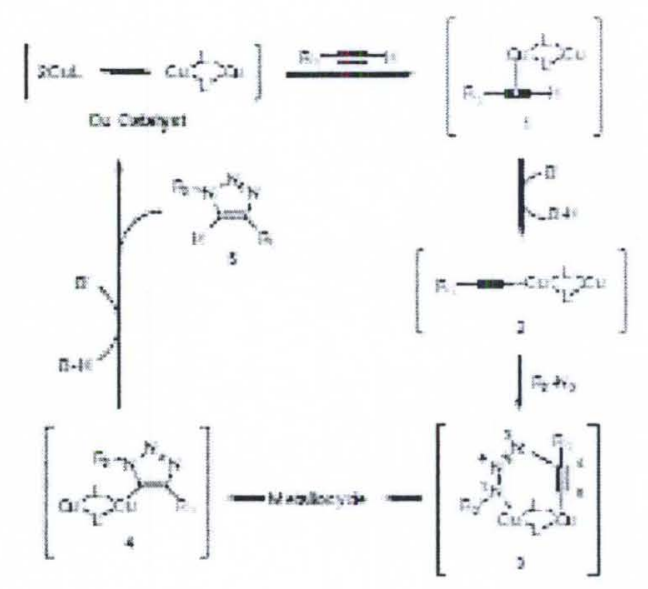

Additionally, Figure $\mathbf{2}$ is the basic click reaction that was utilized in this study, and the triazole product that this reaction produces is more than just a passive linker. The triazoles readily associate with biological targets through hydrogen bonding and dipole interactions ${ }^{20}$.

Figure 2

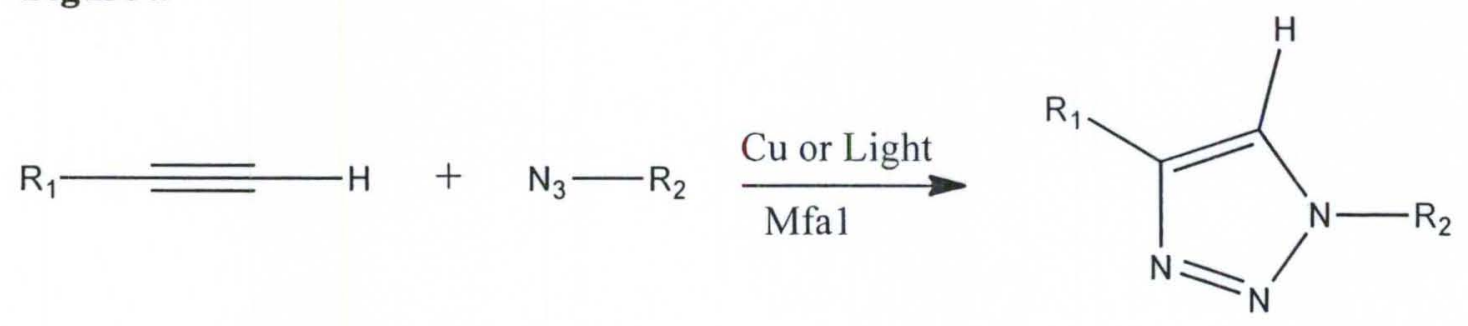

With the philosophy of in situ click chemistry as a guide and the use of the azide/acetylene coupling reaction, our study is a target-guided synthesis that utilizes a 
biologic target (in this case, the Mfal protein) as a scaffold to select reactive chemical precursors and assemble potent inhibitors from these reactive building blocks within the confines of its own active site. Essentially, the Mfal protein will function as a template for the synthesis of its own inhibitors. The activity of compounds that are catalyzed by Mfal can then be assessed using a variety of already established in vitro assays, including protein binding assays, bacterial adherence assays and dual species biofilm cultures. Ultimately, active compounds can be tested for in vivo efficacy using a mouse model of periodontitis that have been developed in the laboratory. 
SCHEMES

Scheme 1.
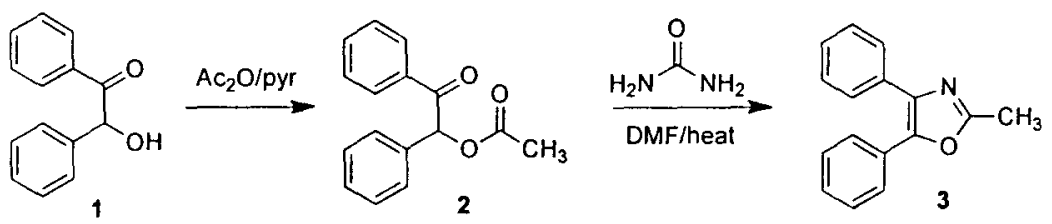

Scheme 2.

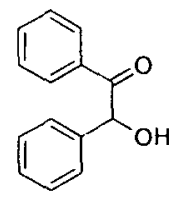

1

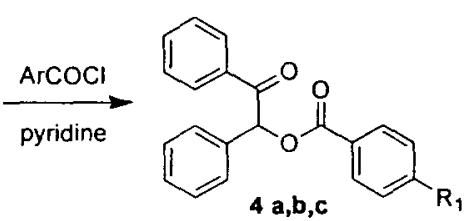

$\mathrm{R}_{1}=\mathrm{H}, \mathrm{NO}_{2}, \mathrm{Br}$

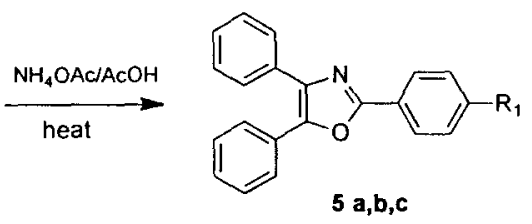

5 a,b,c

10 
Scheme 3.

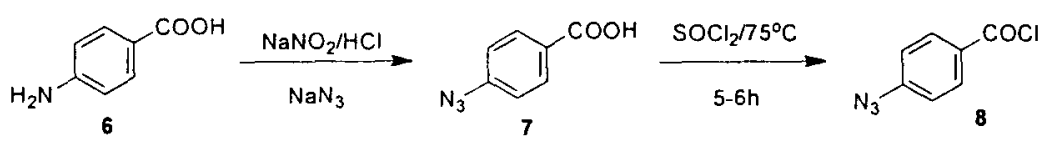
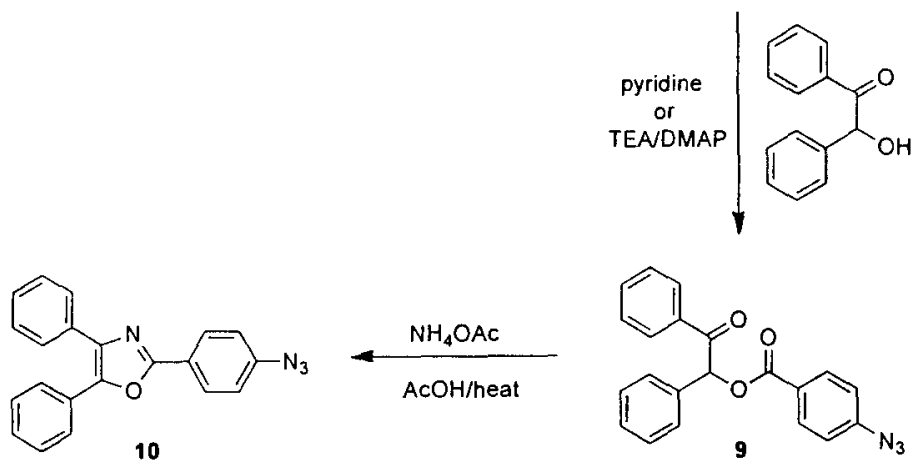

\section{Scheme 4.}
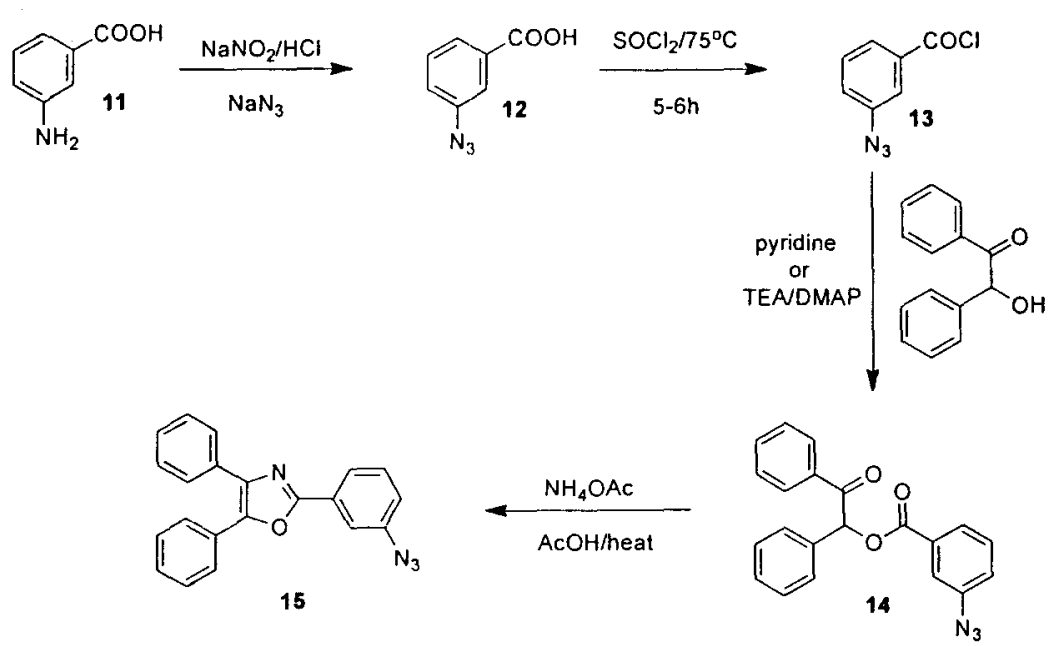

\section{Scheme 5.}

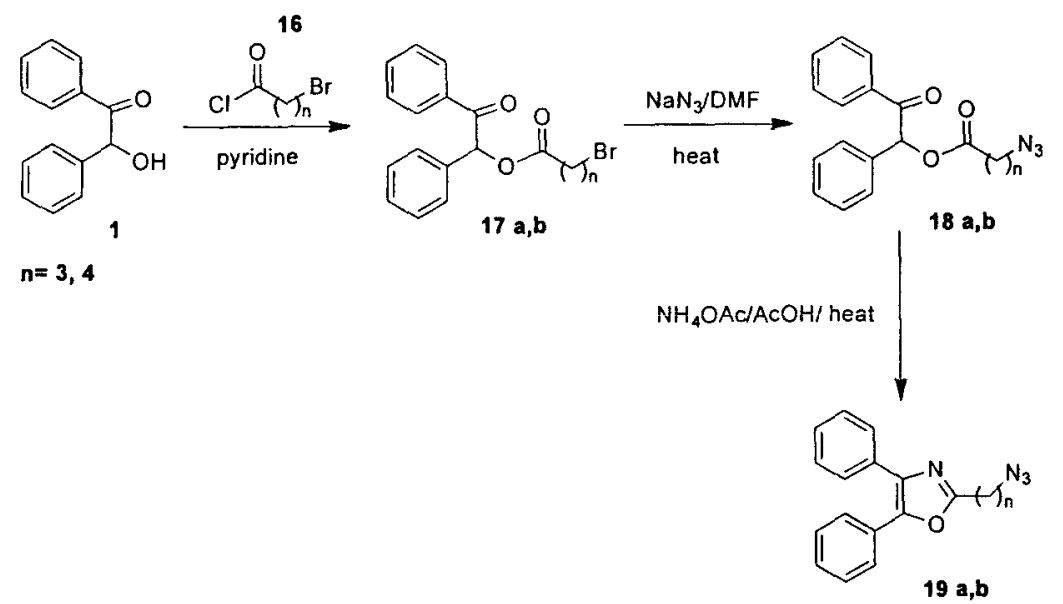


Scheme 6.

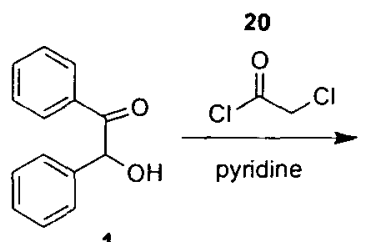<smiles>O=C(CCl)OC(C(=O)c1ccccc1)c1ccccc1</smiles><smiles>N#CCC(=O)OC(C(=O)c1ccccc1)c1ccccc1</smiles>

$\mathrm{NH}_{4} \mathrm{OAC} / \mathrm{ACOH} /$ heat

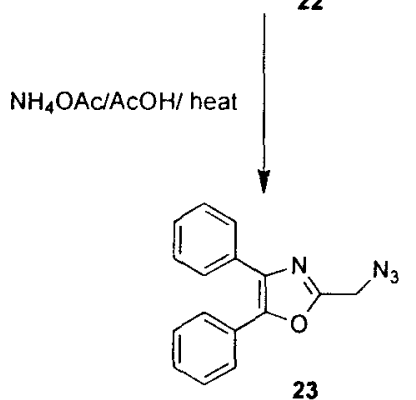

Scheme 7.

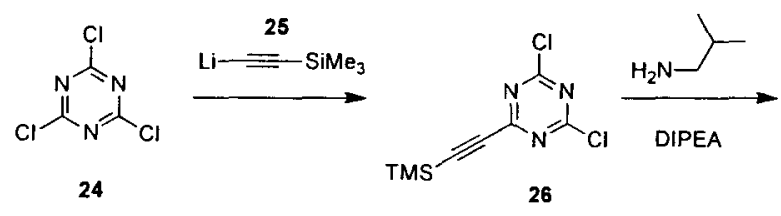<smiles>CCCCNc1nc(C#CS(C)(=O)=O)nc(NCC(C)C)n1</smiles>

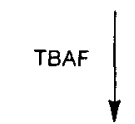<smiles>C#Cc1nc(NCC(C)C)nc(NCC(C)C)n1</smiles>

Scheme 8.

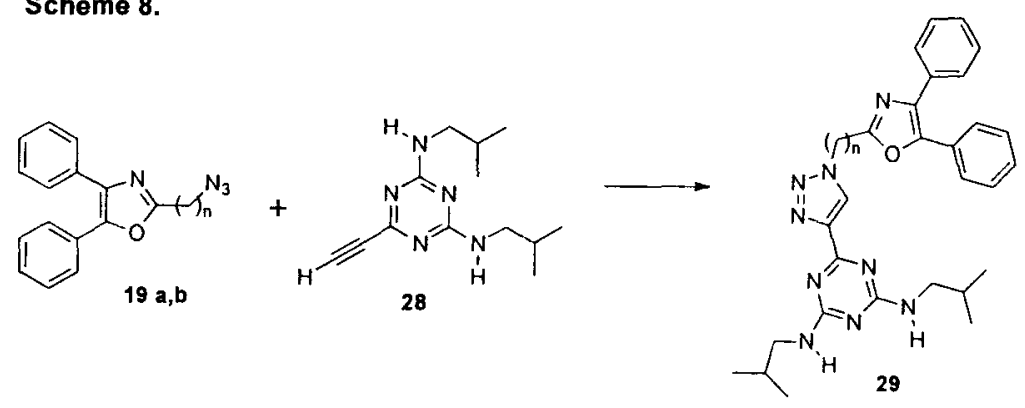




\section{RESULTS}

The BAR peptide analogs were designed based from direct molecular modeling approaches of the VQDLL and NITVK motifs of the BAR region of the $S$. gordonii SspB

protein and the recent $3 \mathrm{D}$ structure of the $\mathrm{C}$-terminal domain of $\mathrm{SspB}^{21}$. The syntheses of the compounds utilized basic scaffolds applied in pharmacophore design and are amenable to scale-up if considerable quantities are required for extensive analog synthesis and bioassays.

Using Gaussian 2003 Program Suite and Visual Molecular Dynamics (VMD) software, the VQDLL sequence was viewed in a 3-Dimensional ball-and-stick image (Figure 2). From this image, it was discovered that the VQDLL motif has an arrangement of an equilateral triangle shape when viewed "head-on." The points of the triangle fall on the central alkane carbons of the two Leucine residues and the Valine residue (Figure 3).

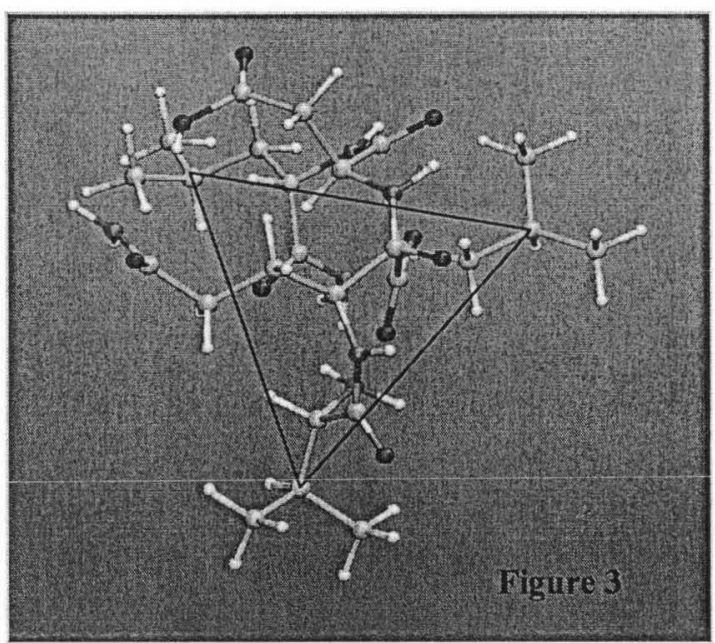


In the designing of the small molecule mimics for the VQDLL sequence, the approach was to put hydrophobic appendages on a triazine core scaffold to mimic the $\mathrm{Val}^{1174}$ and Leu ${ }^{1177-78}$ residues in the VQDLL sequence. The hydrophobic appendages of this molecule will be able to insert deep into the hydrophobic groove of the BAR/Mfal interaction, while the triazine central scaffold is the mimic for the helix backbone which is outside the hydrophobic groove. Also attached to the core scaffold was the essential "click" component, a terminal acetylene functional group.

Specifically, the acetylene-bearing component utilized the symmetrical triazine as the central scaffold with isobutylamine appendages to mimic the Leu ${ }^{1177}$ and Leu ${ }^{1178}$ side chains in the VQDLL motif. The readily available cyanuric chloride (24) was reacted with trimethylsilylacetylene, n-butyllithium, in THF (Scheme 7), which provided the acetylene dichlorotriazine (26). Substitution of the two remaining chlorides was accomplished with isobutylamine to give the triazine-based inhibitor shown (28). Although currently only one triazine based inhibitor has been developed, the length of the acetylenic side chain can be varied as to provide the best mechanics for the click reaction. Similarly, the isobutylamine appendages can be lengthened and varied to optimize binding in the hydrophobic pocket of the Mfal interaction.

The design of the NITVK-motif BAR inhibitor peptide mimetics used an oxazole as the core scaffold structure. Attached to the oxazole core were two phenyl rings extending from the 4 and 5 carbons. As mentioned in the introduction, a previous study found that amino acids containing hydrophobic phenyl groups, Tryptophan and Phenylalanine, that were substituted in the Val ${ }^{185}$ position of the NITVK sequence increased inhibition of the BAR peptide ${ }^{7}$. This suggested that residues in the 1185 
position may be accommodated by a hydrophobic pocket in Mfal. This positive substitution was the basis as to why two hydrophobic phenyl groups were chosen to be attached to the core oxazole. The two phenyls substituted on the oxazole will ideally fit into the hypothesized hydrophobic pocket of the Mfal protein and mimic the $\mathrm{Val}{ }^{1185}$ and the closely positioned Ile $^{1183}$ residue in the NITVK motif. Furthermore, the diphenyl oxazole was chosen because of the inexpensive starting material, benzoin. Many different esters could be created using benzoin as a starting material.

Five total azide oxazole precursor molecules have been created with variations on the 2-carbon azide side chain. The first variation was the number of carbons in the azide alkyl chain. Varying the length of this hydrocarbon varies the length between the triazine click partner and the hydrophobic phenyls attached the oxazole. Testing these three molecules will show whether one distance is more inhibitory than another distance, and thus help provide more information for optimizing the lead compound. In addition, positioning the azide in the para- and meta- positions attached to a phenyl group varies the angle between the triazine and the phenyl appendages of the oxazole. One angle might be more inhibitory than the other and will provide yet another clue into the preference Mfal has for the click molecule.

The oxazole compounds were prepared by a cyclization reaction (Schemes 2-6). Two methods were used to prepare benzoin ester intermediates that were then cyclized into the oxazole: Benzoin, triethylamine, DMAP, dichloromethane, and the acid chloride at $0^{\circ} \mathrm{C}$ (Schemes $3 \& 4$ ) and benozin, acid chloride, and pyridine at $0^{\circ} \mathrm{C}$ (Schemes 2, 5, 6). Both methods were utilized depending on the type of acid chloride used. Two methods were also utilized for the cyclization of the benzoin esters to the oxazole. 
Thiourea in $N, N$-dimethylformamide (Scheme 1). This method worked for all benzoin esters that did not contain an azide group or bromine, but did possess groups, which could be transformed to azides. However, when attempted on the benzoin esters with an azide group, this method did not give product, presumably due to reductive decomposition. Method 2: The benzoin ester combined with ammonium acetate in glacial acetic acid at $118-120^{\circ} \mathrm{C}$ (Scheme 2-6). This method of cyclization was less reactive than the thiourea method, and was capable of cyclizing the azide benzoin esters as well as the esters not containing an azide at approximately the same temperatures.

An example of the future click cycloaddition reaction between the oxazolescaffold azide molecule and the triazine-scaffold acetylene molecule is detailed in Scheme 8. The terminal acetylenes are very reactive toward alkyl or aroyl azides giving 1,2,3-triazoles. This reaction is self-contained and requires no additional reactants, catalysts, or byproducts. When the coupling partners are incubated in the presence of the Mfal protein, a thermal cycloaddition reaction should ensue, and under favorable binding conditions should afford the coupled product triazole. However, if this method of using the Mfal protein as the catalyst does not give the result desired, other catalysts will be attempted, and the click scaffolds will be combined outside of a biological environment. 


\section{METHODS}

Solvents and reagents were ACS grade and used as commercially supplied. Tetrahydrofuran was distilled from a mixture of sodium and benzophenone prior to its use. Analytical thin-layer chromatography (TLC) utilized $0.25 \mathrm{~mm}$ pre-cut glass-backed plates (Merck, Silica Gel $60 \mathrm{~F}_{254}$ ). Thin-layer chromatograms were visualized during chromatographic and extraction runs by rapidly dipping the plates in anisaldehyde/ethanol/sulfuric acid stain or phosphomolybdic acid/ethanol stain and heating (hot plate). Column chromatography was carried out using silica gel 60 (E. Merck 9385, 235-400 mesh/flash) or silica gel 62 (Mallinckrodt 6551, 60-200 mesh/gravity). Melting points were taken on a Thomas Hoover apparatus. Extracts and chromatographic fractions were concentrated with a Büchi rotavapor under water aspirator vacuum. Nuclear magnetic resonance $\left({ }^{1} \mathrm{H}\right.$ and ${ }^{13} \mathrm{C}$ NMR $)$ spectra were recorded with Varian INOVA 500 or VNMRS 400 instruments using $\mathrm{CDCl}_{3}$ as a solvent and internal standard. Infrared spectra (Fourier transform infrared spectroscopy, FTIR) were recorded with a Perkin-Elmer Spectrum 100 instrument.

2-Oxo-1,2-diphenylethyl acetate (2): Benzoin $1(2.0 \mathrm{~g}, 9.40 \mathrm{mmol})$ was dissolved in acetic anhydride $(15 \mathrm{~mL}, 158.70 \mathrm{mmol})$ followed by the addition of two drops of sulfuric acid which resulted in a pale yellow color. The reaction mixture was then stirred under a nitrogen atmosphere at room temperature $(72 \mathrm{~h})$ while monitoring its progress by TLC. The reaction mixture was then dissolved in water and extracted with dichloromethane ( 3 
$x 40 \mathrm{~mL}$ ). The dichloromethane layer was then dried over anhydrous sodium sulfate. After removal of the drying agent by filtration and removal of the solvent by rotary evaporation, the product was found to be of acceptable purity as evidenced by ${ }^{1} \mathrm{H}$ NMR and TLC, Rf: 0.2 (hexane/ethyl acetate, $2: 1$ ): $\mathrm{mp} 83-85^{\circ} \mathrm{C}\left(\right.$ Lit. $^{22} 85-87^{\circ} \mathrm{C}$ )

2-Methyl-4, 5-diphenyloxazole (3): 2-Oxo-1,2-diphenylethyl acetate $2(0.20 \mathrm{~g}, 0.79$ mmol) was dissolved in DMF $(10 \mathrm{~mL})$. Thiourea was then added and the reaction was refluxed $\left(160^{\circ}\right.$, oil bath) under nitrogen atmosphere. As the reaction progressed, the color changed from colorless to a light yellow-orange and had an odorous smell. The reaction was monitored by TLC and when complete, the reaction mixture was dissolved in dichloromethane $(40 \mathrm{~mL})$ and then washed with water $(3 \times 30 \mathrm{~mL})$. The dichloromethane layer was separated and dried over anhydrous sodium sulfate. Removal of the drying agent by filtration and rotary evaporation of the solvent gave a crude oil that was purified by flash chromatography on silica gel (dichloromethane) to provide $\mathbf{3}$ (74\%): Rf: 0.098 (hexane/ethyl acetate, 2:1); FTIR 2920.50; 1220.30; 1502.00, 1588.24

$\mathrm{cm}^{-1} ;{ }^{1} \mathrm{H}$ NMR $\left(400 \mathrm{MHz}, \mathrm{CDCl}_{3}\right) \delta: 2.617(\mathrm{~s}, 3 \mathrm{H}) ; 7.25-7.66\left(\mathrm{~m}, 10 \mathrm{H}\right.$, aromatic) ${ }^{13} \mathrm{C}$ NMR (100 MHz, CDCl3) $\delta 160.35,145.41,134.82,126.46-132.14,13.92$

General Procedure for the Preparation of Benzoin Esters (4a, 4b, 4c): Benzoin (1 eq) was dissolved in pyridine $\left(10 \mathrm{~mL}\right.$ ) followed by cooling the solution to $0^{\circ} \mathrm{C}$ (ice water bath). The aroyl chloride (leq, benzoyl chloride, 4-bromobenzoyl chloride, 4nitrobenzoyl chloride) was then added dropwise to the stirred solution while cooling. The reaction flask was then capped, and after stirring 30 minutes, the cooling bath was removed. The reaction mixture was stirred (18h) while monitoring by TLC. After the 
starting materials were consumed, the reaction mixture was dissolved in dichloromethane $(150 \mathrm{~mL})$ and washed with $5 \%$ aqueous $\mathrm{HCl}(5 \times 100 \mathrm{~mL})$. The organic layer was then separated and dried over anhydrous sodium sulfate. Flash chromatography on silica gel (hexane/ethyl acetate, 9:1) afforded esters $\mathbf{4 a}, \mathbf{4 b}$ and $\mathbf{4 c}$ as crystalline solids in $87 \%, 32 \%$ and $45 \%$ yield respectively. 2-oxo-1,2-diphenylethyl benzoate (4a): m.p. $123-126^{\circ} \mathrm{C}$ (Lit. ${ }^{23} 125-126^{\circ} \mathrm{C}$ ) 2-oxo-1,2-diphenylethyl-4-bromobenzoate (4b): mp. $126-128^{\circ} \mathrm{C}$ $\left(\right.$ Lit. $\left.^{24} \quad 126-127^{\circ} \mathrm{C}\right) . \quad$ 2-Oxo-1,2-diphenylethyl-4-bromobenzoate $\quad(4 \mathrm{c}): \quad$ Rf: 0.24 (hexane/ethyl acetate, 9:1); FTIR 1708.25, 1690.56, 1498.22, $1449.91 \mathrm{~cm}^{-1} ;{ }^{1} \mathrm{H}$ NMR $\left(400 \mathrm{MHz}, \mathrm{CDCl}_{3}\right) \delta: 7.13(\mathrm{~s}, 1 \mathrm{H}) ; 7.36-8.04(\mathrm{~m}, 14 \mathrm{H}) ;{ }^{13} \mathrm{C} \mathrm{NMR}\left(100 \mathrm{MHz}, \mathrm{CDCl}_{3}\right) \delta$ : $193.45,165.35,128.37-134.61,78.22$

General Procedure for the Preparation of Triaryl Oxazole Formation (5a, 5b, 5c): The benzoin ester ( 1 eq, $\mathbf{4 a}, \mathbf{4 b}, 4 \mathbf{c})$ is dissolved in glacial acetic acid $(8 \mathrm{~mL})$. Ammonium acetate (15 eq) was then added and the reaction mixture was refluxed $\left(118^{\circ} \mathrm{C}\right.$, oil bath) under nitrogen $(1.5 \mathrm{~h})$. The reaction was monitored by TLC and when complete, the reaction mixture was dissolved in diethyl ether $(200 \mathrm{~mL})$ and washed with $6 \%$ aqueous sodium hydroxide solution $(4 \times 100 \mathrm{~mL})$. The dichloromethane layer was then separated and dried over anhydrous sodium sulfate. Removal of the drying agent by filtration and rotary evaporation of the solvent gave a crude oil that was purified by flash chromatography on silica gel (hexane/ethyl acetate, 9:1) to furnish the triaryl oxazoles 5a $\left(31 \%, \mathrm{mp} 116-118^{\circ} \mathrm{C}\right.$, Lit. $\left.^{25} 116-117^{\circ} \mathrm{C}\right), \mathbf{5 b}\left(14 \%, \mathrm{mp} 144-145^{\circ} \mathrm{C}\right.$; Lit. $\left.{ }^{26} 145-146^{\circ} \mathrm{C}\right)$ and 5c in $31 \%, 14 \%$, and 5\% yield respectively. 2-(4-Bromophenyl)-4,5-diphenyloxazole (5c): Rf: 0.52 (hexane/ethyl-acetate, 9:1); FTIR 1161.00, 1475.00, $1605.12 \mathrm{~cm}-1 ;{ }^{1} \mathrm{H}$ 
NMR $\left(400 \mathrm{MHz}, \mathrm{CDCl}_{3}\right) \delta: 7.416-8.06(\mathrm{~m}, 14 \mathrm{H}) ;{ }^{13} \mathrm{C} \mathrm{NMR}\left(100 \mathrm{MHz}, \mathrm{CDCl}_{3}\right) \delta:$ $159.26,145.87,136.87,124.93-132.29$

General Procedure for the preparation of 3- and 4-azidobenzoic acid $(7,12)$ : The 3amino- or 4-aminobenzoic acid (1 eq) was dissolved in 10\% aqueous $\mathrm{HCl}$ solution and cooled to $0^{\circ} \mathrm{C}$ (ice bath). Aqueous sodium nitrite (1.1 eq, 20\%) was then added and the reaction mixture was allowed to stir at room temperature (15 min). An $20 \%$ aqueous solution of sodium azide ( $1.2 \mathrm{eq})$ then was added at room temperature which resulted in a vigorous reaction and creating a foaming precipitate which filled the headspace of the reaction flask. The foam precipitate, which was the azidobenzoic acid product, was collected by vacuum filtration while washing the filter cake with water and excess solvent was removed by rotary evaporation. The slightly yellow-white solids 4-Azido Benzoic Acid: mp 189-190 ${ }^{\circ} \mathrm{C}$, it. $^{27} 188.5-190^{\circ} \mathrm{C}$ and 3-Azido Benzoic Acid: mp 176$178^{\circ} \mathrm{C}$, Lit. ${ }^{28} 176-177^{\circ} \mathrm{C}$ were of sufficient purity to use in the next step.

General Procedure for the Preparation of 3- and 4-azidobenzoyl chloride (8, 13): The azidobenzoic acid 7 or $\mathbf{1 2}$ (1 eq) was dissolved in thionyl chloride (4.5eq). The mixture is heated to reflux $\left(75^{\circ} \mathrm{C}\right)$, and allowed to stir $(5 \mathrm{~h})$. The reaction mixture was then allowed to stir overnight at room temperature. Thionyl chloride was then removed by adding dichloromethane $(10 \mathrm{~mL})$ and concentrating with the rotary evaporator under aspirator vacuum. The addition of dichloromethane and vacuum rotary evaporation was repeated (3X) to give the acid chloride as an oil. The azidobenzoyl chloride was used in esterification step without further purification. 
General Procedure for the Preparation of 2-oxo-1,2-diphenylethyl-3-azidobenzoate (9) and 2-oxo-1,2-diphenylethyl-4-azidobenzoate (14): Benzoin (1 eq), triethylamine (leq), and 4-dimethylaminopyridine (0.1 eq) are dissolved in dichloromethane $(10 \mathrm{~mL})$ at $0^{\circ} \mathrm{C}$ (ice water bath). The azidobenzoyl chloride (leq ) in dichloromethane $(5 \mathrm{~mL})$ is gradually introduced into the reaction flask while stirring. The reaction mixture was allowed to stir (3h) at room temperature while monitoring by TLC. Upon completion of the reaction as evidenced by TLC, the reaction mixture was dissolved in diethyl ether $(100 \mathrm{~mL})$ and washed with $5 \%$ aqueous $\mathrm{HCl}$ solution $(4 \times 50 \mathrm{~mL})$ followed by $5 \%$ aqueous sodium bicarbonate $(2 \times 100 \mathrm{~mL})$. The organic layer was separated and dried over anhydrous sodium sulfate. Removal of the drying agent by filtration and rotary evaporation of the solvent gave a crude solid that was purified by flash chromatography on silica gel (hexane/EtOAc, 4:1) to obtain 9 and 14 in $72 \%$ and $80 \%$ yield. 2-oxo-1,2diphenylethyl-4-azidobenzoate (9): $\quad$ Rf: 0.42 (hexane/ethyl acetate, 4:1); FTIR $2118.00,1174.79,1710.42,1693.73,1448.18,1504.39 \mathrm{~cm}^{-1} ;{ }^{1} \mathrm{H}$ NMR: $(400 \mathrm{MHz}$, $\left.\mathrm{CDCl}_{3}\right) \delta: 6.96(\mathrm{~s}, 1 \mathrm{H}) ; 6.99-7.33(\mathrm{~m}, 14 \mathrm{H}) ; 7.90-7.92(\mathrm{~d}, 2 \mathrm{H}, \mathrm{J}=7.99) ; 8.01-8.04(\mathrm{~d}, 2 \mathrm{H})$;

${ }^{13} \mathrm{C}$ NMR $\left(100 \mathrm{MHz}, \mathrm{CDCl}_{3}\right) \delta: 193.62,165.20,145.29,118.81-145.20,78.06$. 2-oxo1,2-diphenylethyl-3-azidobenzoate (14): Rf: 0.53 (hexane/ethylacetate, 4:1); FTIR $2124.85,1299.51,1711.90,1695.45,1482.43,1448.61 \mathrm{~cm}^{-1} ;{ }^{1} \mathrm{H}$ NMR: $(400 \mathrm{MHz}$, $\left.\mathrm{CDCl}_{3}\right) \delta: 7.00(\mathrm{~s}, 1 \mathrm{H}) ; 7.08-7.90(\mathrm{~m}, 14 \mathrm{H}) ;{ }^{13} \mathrm{C} \mathrm{NMR}\left(100 \mathrm{MHz}, \mathrm{CDCl}_{3}\right) \delta: 193.42$ $165.20,120.16-140.62,78.33$

General Procedure for the Preparation of 2-(3-azidophenyl)-4,5-diphenyloxazole (10) and 2-(4-azidophenyl)-4,5-diphenyloxazole (15): The azido benzoic esters 9 or 14 (1eq) and ammonium acetate (15 eq) are combined in glacial acetic acid $(10 \mathrm{~mL})$. The 
mixture is allowed to react at reflux $\left(118^{\circ} \mathrm{C}\right)$ for 2 hours under an atmosphere of nitrogen. The reaction mixture was monitored by TLC and when complete, the reaction mixture was dissolved in diethyl ether $(110 \mathrm{~mL})$ and washed with $\mathrm{NaOH}$ solution $(3 \times 100 \mathrm{~mL})$. The diethyl ether layer is separated and dried over anhydrous sodium sulfate. Removal of the drying agent by filtration and rotary evaporation of the solvent gave a crude oil that was purified by flash chromatography on silica gel (hexane/ethylacetate, $4: 1$ ) to obtain $\mathbf{1 0}$ and $\mathbf{1 5}$ in $61 \%$ and $80 \%$ yield. 2-(4-azidophenyl)-4,5-diphenyloxazole (10): Rf: 0.60 (hexane/ethyl acetate, 4:1); FTIR: 2088.97, 1278.93, 1608.72, 1493.77, $1087.95 \mathrm{~cm}^{-1}$; ${ }^{1} \mathrm{H}$ NMR: $\left(500 \mathrm{MHz}, \mathrm{CDCl}_{3}\right)$ 7.21-8.13 (m, 14H, aromatic); ${ }^{13} \mathrm{C} \mathrm{NMR}\left(125 \mathrm{MHz}, \mathrm{CDCl}_{3}\right) \delta$ : 159.46, 145.61, 142.26, 136.47, 119.34-132.01 2-(3-azidophenyl)-4,5-diphenyloxazole (15): Rf: 0.53 (hexane/ethyl acetate, 4:1); FTIR: 2146.37, 1276.93, 1590.12, $1590.35 \mathrm{~cm}^{-}$

'; ${ }^{1} \mathrm{H}$ NMR: (400 MHz, $\mathrm{CDCl}_{3}$ ) $\delta: ~ 7.09-7.94$ (m, 14H, aromatic); ${ }^{13} \mathrm{C} \mathrm{NMR}(100 \mathrm{MHz}$, $\left.\mathrm{CDCl}_{3}\right) \delta: \quad 159.09,145.96,140.87,136.85,116.84-132.25$. HRMS

General Procedure for the Preparation of Acid Chlorides (16a, 16b): 5Bromovaleric acid (1 eq) or 4-bromobutyric acid (1 eq) was dissolved in thionyl chloride (4.5 eq). The reaction mixture was then refluxed $\left(75^{\circ} \mathrm{C}\right.$, oil bath) under nitrogen atmosphere overnight. The excess thionyl chloride was removed by adding dichloromethane $(25 \mathrm{~mL})$ and removing using a rotary evaporator under aspirator vacuum. The addition of the dichloromethane and rotary evaporation was repeated (3x) which yielded the acid chloride as an oil. The 5-bromovaleryl chloride 16a or the 4bromobutyryl chloride $\mathbf{1 6 b}$ were used without further purification in the next step. 
General Procedure for the Preparation of the Bromoacyl Esters (17a, 17b): Benzoin (1 eq) was dissolved in pyridine $(12 \mathrm{~mL})$ followed by cooling the solution to $0^{\circ} \mathrm{C}$ (ice water bath). The acid chloride 16a or 16b (leq) was then added dropwise to the stirred solution while cooling. The reaction flask was capped, and after 30 minutes, the cooling bath was removed. The reaction mixture was stirred (4h) while monitoring by TLC. After the starting materials were consumed, the reaction mixture was then dissolved in dichloromethane $(300 \mathrm{~mL})$ and washed with $5 \%$ aqueous $\mathrm{HCl}(5 \times 120 \mathrm{~mL})$. The organic layer was then separated and dried over anhydrous sodium sulfate. Flash chromatography on silica gel (hexane/ethyl acetate, 6:1) afforded esters $\mathbf{1 7 \mathbf { a }}$ and $\mathbf{1 7} \mathbf{b}$ as oils in $70 \%$ and $23 \%$ yield respectively: 2-Oxo-1,2-diphenylethyl-4-bromobutanoate (17a): Rf: 0.49 (hexane/ethylacetate, 4:1); FTIR: 3063.60, 1708.60, 1692.03, 1588.70, $1531.70 \mathrm{~cm}^{-1} ;{ }^{1} \mathrm{H}$ NMR $\left(400 \mathrm{MHz}, \mathrm{CDCl}_{3}\right) \delta: 2.21-2.23(\mathrm{t}, 2 \mathrm{H}) ; 2.60-2.69(\mathrm{~m}, 2 \mathrm{H}) ; 3.45-$ $3.47(\mathrm{t}, 2 \mathrm{H}) ; 6.85(\mathrm{~s}, 1 \mathrm{H}) ; 7.28-8.01(\mathrm{~m}, 10 \mathrm{H}) ;{ }^{13} \mathrm{C} \mathrm{NMR}\left(100 \mathrm{MHz}, \mathrm{CDCl}_{3}\right) \delta: 193.66$, $172.08, \quad 134.56,133.57,128.70-129.43,77.85,32.55,32.34,27.83 \quad 2-0 \times 0-1,2-$ diphenylethyl-5-bromopentoate (17b): Rf: 0.47 (hexane/ethyl acetate, 4:1); FTIR: 1734.38, 1693.88, 1597.38, $1448.37 \mathrm{~cm}^{-1} ;{ }^{1} \mathrm{H}$ NMR $\left(400 \mathrm{MHz}, \mathrm{CDCl}_{3}\right) \delta: 1.81-1.87(\mathrm{~m}$, $2 \mathrm{H}) ; 1.91-1.98(\mathrm{~m}, 2 \mathrm{H}) ; 2.44-2.59(\mathrm{~m}, 2 \mathrm{H}) ; 3.40-3.43(\mathrm{t}, 2 \mathrm{H}) ; 6.85(\mathrm{~s}, 1 \mathrm{H}), 7.35-7.93(\mathrm{~m}$, $10 \mathrm{H}) ;{ }^{13} \mathrm{C} \mathrm{NMR}\left(100 \mathrm{MHz}, \mathrm{CDCl}_{3}\right) \delta: 193.75,172.63,134.59,133.49,128.07-128.83$, $60.25,44.55,33.09,31.76,23.38$.

\section{General Procedure for the Conversion of the Brominated Esters 17a, 17b to Azido} Esters (18a, 18b): The halogenated ester 17a or 17b (1 eq) was dissolved in DMF. Sodium azide $(1.1 \mathrm{eq})$ was then added and the reaction mixture was refluxed $\left(80^{\circ} \mathrm{C}\right.$, oil bath) under a nitrogen atmosphere (4h). The reaction mixture was monitored by TLC 
and when complete, the DMF was removed under high vacuum. The crude oil was purified by flash chromatography on silica gel (hexane/ethylacetate, 9:1) to obtain 18a and $\mathbf{1 8 b}$ in $85 \%$ and $56 \%$ yield respectively: 2-oxo-1,2-diphenylethyl-4-azidobutanoate (18a): Rf: 0.44 (hexane/ethylacetate, 4:1); FTIR: 2096.16, 1448.47, 1734.69, 1693.83, 1580.74, $1496.07 \mathrm{~cm}^{-1} ;{ }^{1} \mathrm{H}$ NMR $\left(500 \mathrm{MHz}, \mathrm{CDCl}_{3}\right) \delta: 1.82-1.92(\mathrm{t}, 2 \mathrm{H}) ; 2.41-2.60(\mathrm{~m}$, $2 \mathrm{H}) ; 3.28-3.38(\mathrm{t}, 2 \mathrm{H}) ; 6.82(\mathrm{~s}, 1 \mathrm{H}) ; 7.25-7.98\left(\mathrm{~m}, 10 \mathrm{H}\right.$, aromatic); ${ }^{13} \mathrm{C}$ NMR $(125 \mathrm{MHz}$, $\left.\mathrm{CDCl}_{3}\right) \delta: 193.65,172.23,134.55,133.56,128.69-129.19,77.86,50.54,30.95,24.33 .2-$ oxo-1,2-diphenylethyl-5-azidopentanoate (18b): Rf: 0.22 (hexane/ethyl acetate, 4:1); FTIR 2092.58, 1224.81, 1734.84, 1694.21, 1597.46, $1448.81 \mathrm{~cm}^{-1} ;{ }^{1} \mathrm{H}$ NMR: $(500 \mathrm{MHz}$, $\left.\mathrm{CDCl}_{3}\right) \delta: 1.52-1.61(\mathrm{~m}, 2 \mathrm{H}) ; 1.62-1.71(\mathrm{~m}, 2 \mathrm{H}) ; 2.32-2.49(\mathrm{~m}, 2 \mathrm{H}) ; 3.14-3.22(\mathrm{t}, 2 \mathrm{H})$; $6.782(\mathrm{~s}, 1 \mathrm{H}) ; 7.24-7.85(\mathrm{~m}, 10 \mathrm{H}) ;{ }^{13} \mathrm{C} \mathrm{NMR}\left(125 \mathrm{MHz}, \mathrm{CDCl}_{3}\right) \delta: 193.76,172.64$, $134.60,133.55,128.66-129.36,77.66,51.02,33.33,28.13,22.04$.

General Procedure for the Preparation of the Azidoalkyl Oxazoles (19a, 19b): The azido ester $\mathbf{1 8 a}, \mathbf{1 8 b}(1 \mathrm{eq})$ was dissolved in glacial acetic acid $(10 \mathrm{~mL})$. Ammonium acetate (15 eq) was then added and the reaction mixture was refluxed $\left(118^{\circ} \mathrm{C}\right.$, oil bath) under a nitrogen atmosphere $(2 \mathrm{~h})$. The reaction mixture was monitored by TLC, and when complete as evidenced by the disappearance of the ester, the reaction mixture was dissolved in diethyl ether $(100 \mathrm{~mL})$ and washed with aqueous sodium hydroxide $(3 \times 100$ $\mathrm{mL}$ ). The organic layer was separated and dried over anhydrous sodium sulfate. Flash chromatography on silica gel (hexane/ethylacetate, 8:1) afforded 19a and 19b in 64\% and 81\% yield; 2-(3-azidopropyl)-4,5-diphenyloxazole (19a): Rf: 0.30 (hexane/ethylacetate, 8:1); FTIR 2094.21, 1218.91, 2933.26, 1570.34, 1501.98, $1218.91 \mathrm{~cm}^{-1}$; ${ }^{1}$ H NMR: $(500$ $\left.\mathrm{MHz}, \mathrm{CDCl}_{3}\right) \delta: 2.16-2.19(\mathrm{~m}, 2 \mathrm{H}) ; 3.02-3.06(\mathrm{t}, 2 \mathrm{H}) ; 3.49-3.51(\mathrm{t}, 2 \mathrm{H}) ; 7.35-7.67(\mathrm{~m}$, 
$10 \mathrm{H}) ;{ }^{13} \mathrm{C}$ NMR $\left(125 \mathrm{MHz}, \mathrm{CDCl}_{3}\right) \delta: 162.68,145.69,134.22,126.54-131.34,50.55$, 26.31, 25.18. 2-(4-azidobutyl)-4,5-diphenyloxazole (19b): Rf: 0.50 (hexane/ethyl acetate, 4:1); FTIR 2936.78, 2091.06, 1218.94, 1570.01, 1501.95, $1157.14 \mathrm{~cm}^{-1} ;{ }^{1} \mathrm{H}$ NMR: $\left(500 \mathrm{MHz}, \mathrm{CDCl}_{3}\right) \delta: 1.77-1.80(\mathrm{~m}, 2 \mathrm{H}) ; 1.96-2.0(\mathrm{~m}, 2 \mathrm{H}) ; 2.92-2.95(\mathrm{t}, 2 \mathrm{H})$; 3.36-3.39 (t, 2H); 7.336-7.668 (m, 10H); ${ }^{13} \mathrm{C} \mathrm{NMR}\left(125 \mathrm{MHz}, \mathrm{CDCl}_{3}\right)$ 8: 162.99, 145.35, $132.23,126.47-128.92,51.04,28.35,27.65,24.27$.

2-Oxo-1,2-diphenylethyl-2-chloroacetate (21): Benzoin $(0.50 \mathrm{~g}, 2.37 \mathrm{mmol})$ and 4 dimethylaminopyridine $(0.29 \mathrm{~g}, 2.37 \mathrm{mmol})$ were dissolved in dichloromethane $(20 \mathrm{~mL})$ and the solution was allowed to stir at $0^{\circ} \mathrm{C}$. Chloroacetyl chloride $\mathbf{2 0}(0.21 \mathrm{~mL}, 2.60$ mmol) was added dropwise by syringe. The reaction mixture was then stirred under nitrogen at $0^{\circ} \mathrm{C}(4 \mathrm{~h})$ while monitoring by TLC. Upon completion of the reaction, the reaction mixture was dissolved in diethyl ether $(100 \mathrm{~mL})$ and washed with water $(2 \times 90$ $\mathrm{mL}), 5 \%$ aqueous $\mathrm{HCl}(1 \times 90 \mathrm{~mL})$, and $5 \%$ aqueous sodium bicarbonate $(1 \times 90 \mathrm{~mL})$. The diethyl ether layer was separated and dried over anhydrous sodium sulfate. After removal of the drying agent by filtration and removal of solvent by rotary evaporation, the product chloroacetyl ester 21 was obtained in $95 \%$ yield and found to be of reasonable purity as evidenced by ${ }^{1} \mathrm{H}$ NMR and TLC. Rf: 0.51 (hexane/ethylacetate, 4:1); FTIR 2960.22, 1734.54, 1694.12, 1597.47, 1495.83, $1224.81 \mathrm{~cm}^{-1} ;{ }^{1} \mathrm{H}$ NMR $(500 \mathrm{MHz}$,

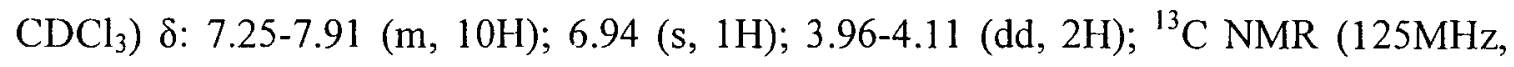
$\left.\mathrm{CDCl}_{3}\right) \delta: 192.62,167.91,128.71-134.17,78.75,50.11$

2-Oxo-1,2-diphenylethyl-2-azidoacetate (22): 2-oxo-1,2-diphenylethyl-2-chloroacetate $21(0.72 \mathrm{~g}, 2.50 \mathrm{mmol})$ is dissolved in DMF $(5 \mathrm{~mL})$. Sodium azide $(0.18 \mathrm{~g}, 2.77 \mathrm{mmol})$ 
was then added and the reaction mixture was refluxed $\left(80^{\circ} \mathrm{C}\right.$, oil bath) under nitrogen (4h). The reaction mixture was monitored by TLC and when complete, the DMF was removed from the reaction mixture by rotary evaporation and then high vacuum. The crude oil was purified by flash chromatography on silica gel (hexane/ethyl acetate, 9:1) to obtain the azido ester 22 in 22\% yield: Rf: 0.49 (hexane/ethyl acetate, 4:1); FTIR $2104.56,1173.01,1747.90,1692.58,1597.22,1448.76 \mathrm{~cm}-1 ;{ }^{1} \mathrm{H}$ NMR: $(500 \mathrm{MHz}$ $\left.\mathrm{CDCl}_{3}\right) \delta: 7.38-7.94(\mathrm{~m}, 10 \mathrm{H}) ; 6.97(\mathrm{~s}, 1 \mathrm{H}) ; 4.03-4.10(\mathrm{dd}, 2 \mathrm{H}) ;{ }^{13} \mathrm{C}$ NMR $(125 \mathrm{MHz}$, $\left.\mathrm{CDCl}_{3}\right) \delta: 192.72,167.99,128.44-134.99,78.79,50.09$

2-(azidomethyl)-4,5-diphenyloxazole (23): 2-Oxo-1,2-diphenylethyl-2-azidoacetate 22 $(0.14 \mathrm{~g}, 0.48 \mathrm{mmol})$ was dissolved in glacial acetic acid $(\mathrm{XXmL})$. Ammonium acetate $(0.57 \mathrm{~g}, 7.40 \mathrm{mmol})$ was then added and the reaction mixture was refluxed $\left(118^{\circ} \mathrm{C}\right.$, oil bath) under a nitrogen atmosphere ( $2 \mathrm{~h}$ ). The reaction was monitored by TLC and when it was complete, the reaction mixture was dissolved in diethyl ether $(100 \mathrm{~mL})$ and washed with $7 \%$ aqueous sodium hydroxide solution $(3 \times 100 \mathrm{~mL})$. The diethyl ether layer was separated and dried over anhydrous sodium sulfate. Removal of the drying agent by filtration and rotary evaporation of the solvent gave a crude oil that was purified by flash chromatography on silica gel (hexane:ethylacetate, $8: 1$ ) to provide the azidomethyl oxazole 23 in $46 \%$ yield: Rf: 0.58 (hexane/ethylacetate, 4:1); FTIR 2098, 1444.19, $1569.48,1604.78,1251.13 \mathrm{~cm}^{-1} ;{ }^{1} \mathrm{H}$ NMR $\left(400 \mathrm{MHz}, \mathrm{CDCl}_{3}\right) \delta: 4.44(\mathrm{~s}, 2 \mathrm{H}) ; 7.18-7.59$ $\left(\mathrm{m}, 10 \mathrm{H} ;{ }^{13} \mathrm{C}\right.$ NMR $\left(125 \mathrm{MHz}, \mathrm{CDCl}_{3}\right) \delta: 157.23,146.77,135.52,126.69-131.80,46.75$

2,4-Dichloro-6-((trimethylsilyl)ethynyl)-1,3,5-triazine (26): Trimethylsilylacetylene $(0.50 \mathrm{~mL}, 3.51 \mathrm{mmol})$ was dissolved in freshly-distilled anhydrous THF $(3 \mathrm{~mL}) . \quad \mathrm{n}$ - 
butyllithium $(2.20 \mathrm{ml}, 3.52 \mathrm{mmol})$ was then added dropwise by syringe under an atmosphere of argon. The reaction mixture was stirred (10 min) under argon atmosphere at $0^{\circ} \mathrm{C}$ (ice bath). The lithiotrimethylsilylacetylene 25 was then canulated over a 30 minute period into a solution of cyanuric chloride $(24,0.65 \mathrm{~g}, 3.52 \mathrm{mmol})$ dissolved in anhydrous THF ( $4 \mathrm{~mL})$ The reaction mixture was stirred under nitrogen at $0^{\circ} \mathrm{C}$ (ice bath). A sample was taken from the reaction mixture and was found to be the product as evidenced by ${ }^{1} \mathrm{H}$ NMR and ${ }^{13} \mathrm{C}$ NMR: ${ }^{1} \mathrm{H}$ NMR $\left(400 \mathrm{MHz}, \mathrm{CDCl}_{3}\right) \delta: 0.00(\mathrm{~s}, 9 \mathrm{H}) ;{ }^{13} \mathrm{C}$ $\operatorname{NMR}\left(100 \mathrm{MHz}, \mathrm{CDCl}_{3}\right) \delta: 172.93,161.97,107.07,99.77,0.00$

\section{N2,N4-diisobutyl-6-((trimethylsilyl)ethynyl)-1,3,5-triazine-2,4-diamine}

Isobutylamine $(0.73 \mathrm{~mL}, 7.38 \mathrm{mmol})$ and diisopropylethylamine $(1.53 \mathrm{~mL}, 8.78 \mathrm{mmol})$ were dissolved THF (2 mL). 2,4-dichloro-6-((trimethylsilyl)ethynyl)-1,3,5-triazine (above) $26(0.85 \mathrm{~g}, 3.45 \mathrm{mmol})$ was then added by syringe and the reaction mixture was left to react at room temperature (12h) while monitoring the progress by TLC. When complete, the reaction mixture was dissolved in dichloromethane $(150 \mathrm{~mL})$ and then washed with water $(3 \times 80 \mathrm{~mL})$. The dichloromethane layer was separated and dried over anhydrous sodium sulfate. Removal of the drying agent by filtration and rotary evaporation of the solvent gave a crude solid that was purified by flash chromatography on silica gel (hexane/ethylacetate, 9:1) to afford 27 (1.3\%): Rf: 0.79 (hexane/ethylacetate, 2:1). ${ }^{1} \mathrm{H}$ NMR (400 MHz, $\left.\mathrm{CDCl}_{3}\right) \delta: 0.67-0.69(\mathrm{~d}, 12 \mathrm{H}), 1.57-1.66(\mathrm{~m}, 1 \mathrm{H}), 2.91-3.02(\mathrm{dt}$, $4 \mathrm{H}) ;{ }^{13} \mathrm{C} \mathrm{NMR}\left(100 \mathrm{MHz}, \mathrm{CDCl}_{3}\right) \delta: 165.32,157.15,101.47,58.67,31.45,28.78,20.65$, 0.00 
6-ethynyl-N2,N4-diisobutyl-1,3,5-triazine-2,4-diamine (28): N2,N4-diisobutyl-6((trimethyl-silyl)ethynyl)-1,3,5-triazine-2,4-diamine (27, $14.5 \mathrm{mg}, 0.045 \mathrm{mmol})$ was dissolved in THF $(1 \mathrm{~mL})$. Tetrabutylammonium fluoride $(0.59 \mathrm{~mL}, 2.04 \mathrm{mmol})$ was then added and the reaction mixture was left to react at room temperature $(30 \mathrm{~min})$. The reaction was monitored by TLC and when complete, the solvent was removed from the reaction mixture by rotary evaporation to give a crude solid that was purified by flash chromatography on silica gel (hexane/ethyl acetate, $2: 1$ ) to attain 28 in $12 \%$ yield. 6ethynyl-N2,N4-diisobutyl-1,3,5-triazine-2,4-diamine (28): Rf: 0.14 (hexane/ethylacetate, 2:1). ${ }^{1} \mathrm{H}$ NMR (400 MHz, $\left.\mathrm{CDCl}_{3}\right) \delta: 0.92-0.94(\mathrm{~d}, 12 \mathrm{H}), 2.15-2.16(\mathrm{~d}, 4 \mathrm{H}), 3.21-3.27(\mathrm{~m}$, 2H), $5.29(\mathrm{~s}, 1 \mathrm{H})$. 


\section{DISCUSSION}

In order for $P$. gingivalis to become a pathogenic bacterium in the development of periodontal disease, it must first become established in the oral cavity. It becomes established in the oral cavity by adhering to select species of oral streptococci ${ }^{8}$, specifically $S$. gordonii. Thus, this interspecies adherence activity represents a therapeutic target for controlling periodontal disease.

Previous studies have shown that adherence of $P$. gingivalis to streptococci is mediated by a protein-protein interaction between Mfa of $P$. gingivalis and $\mathrm{SspB}$ of $S$. gordonii $^{2}$. The active site regions of the $\mathrm{SspB}$ protein have been determined ${ }^{7,15}$, and a peptide composed of these active sites was developed ${ }^{7}$. This synthetic peptide, named the BAR peptide, was proven to be a potent inhibitor of the $P$. gingivalis-S. gordonii interaction ${ }^{7}$. In this study, we developed several small organic click molecules mimicking certain characteristics of the BAR peptide, with the ultimate goal of developing a compound that is an equal or greater inhibitor of the $P$. gingivalis-S. gordonii interaction.

The six click components that have been developed will be tested for their bioactivity. The first bioactivity assessment will be using a series of in vitro binding inhibition assays. This test will not only assess the bioactivity of the compounds, but will also assess whether these compounds are toxic to the proteins. The $S$.gordonii and $P$. gingivalis will be grown in the presence of increasing concentrations of the inhibitor and comparing growth with that of bacteria grown in medium alone. It is not anticipated that 
the click molecules will be toxic to the bacteria, however if they are, they could represent new antibiotics. The second bioactivity assessment will measure the inhibition of $P$. gingivalis-S. gordonii biofilm formation using an established flow cell biofilm culture system. The mimetic compounds will be pre-incubated with $P$. gingivalis cells at varying concentrations prior to inoculation into the flow cell chamber containing the established $S$. gordonii cells. The $P$. gingivalis-S.gordonii biofilms will be visualized using a confocal laser scanning microscope, and the number of microcolonies that form per microscope field and the depth of each microcolony will be recorded and analyzed using the COMSTAT program. Lastly, the active compounds will be tested for in vivo efficacy using the Baker mouse model of periodontitis.

If the initial bioactivity assessments do not show significant inhibition at reasonably low concentrations, the basic scaffolds are flexible, and can be quickly modified to improve activity. There are several areas in which the core structures can be modified. Firstly, every appendage to both the oxazole and triazine structures can be altered in the type of hydrophobic appendage attached, a basic appendage could be added, or a charged functional group could be included. Secondly, both the oxazole and triazine structures produce only planar molecules. Depending on the results of the bioactivity assessments, it might be beneficial to change one or both of these core structures to a molecule that has stereochemistry and provides 3-dimensionality. There are many different options in which we can modify these initial compounds in order to optimize inhibition.

The benefits that will stem from this study are both numerous and diverse. Not only will this study help in a biological sense for the treatment of periodontal diseases, 
but this study also will help in the progression of the "click-chemistry" movement. Currently, click chemistry is still a relatively new idea, and many "click-readied" building units and "click products" are not yet commercially available. Therefore, any new azide or acetylene molecules that can be created will help build the library of click building units. The more known azide and acetylene compounds prepared, and ideally commercially available azide and acetylene compounds, the quicker new pharmaceutical compounds can be developed. 


\section{REFERENCES}

1. Peterson PE, B.D., Ogawa H, Estupinan-Day S, Ndiaye C., The global burden of oral diseases and risks to oral health. Bull World Health Organ, 2005. 83: p. 661669.

2. Brown, L.J.J., B.A.; Wall, T.P., The economics of periodontal disease. Periodontol. 2000, 2002. 29: p. 223-234.

3. Kamer, A.R.C., R.G.; Dasanayake, A.P.; Brys, M.; Glodzik-Sobanska, L; de Leon, M.J., Inflammation and Alzheimer's disease: possible role of periodontal diseases. Alzheimer's Dement, 2008. 4: p. 242-50.

4. Teles, R.P.H., A.D.; Socransky, S.S.; , Microbiological goals of periodontal therapy. Periodontol 2000, 2006. 42: p. 180-218.

5. Dumitrescu, A.L., Etiology and Pathogenesis of Periodontal Disease2010, London: Springer Heidelberg Dordrecht.

6. Hajishengallis, G.L., S.; Payne, M.A.; Hashim, A.; Jotwani, R., Low-abundance biofilm species orchestrates inflammatory periodontal disease through the commensal microbiota and complement. Cell Host and Microbe, 2011. 10(5): p. 497-506.

7. Daep, C.A.J., D.M.; Lamont, R.J.; Demuth, D.R., Structural Characterization of Peptide-Mediated Inhibition of Porphyromonas gingivalis Biofilm Formation. Infection and Immunity, 2006. 74(10): p. 5756-5762.

8. Chung, W.O.D., D.R.; Lamont, R.J., Identification of a Porphyromonas Gingivalis receptor for the Streptococcus gordonii SspB protein. Infect. Immun., 2000.68 : p. 6758-6762.

9. Maeda, K.N., H.; Kuboniwa, M.; Kataoka, K.; Nishida, N.; Tanaka, M.; Shizukuishi, S., Characterization of binding of Streptococcus oralis glyceraldehyde 3-phosphate dehydrogenase to Porphyromonas gingivalis major fimbriae. Infect. Immun., 2004. 72: p. 5475-5477.

10. Sohar, H.T.G., R.J., Identification of glyceraldehyde 3-phosphate dehydrogenase of epithelial cells as a second molecule that binds to Porphyromonas gingivalis fimbriae. . FEMS Immunol. Med. Microbiol., 2005. 45: p. 25-30. 
11. Park, Y., M. R. Simionato, K. Sekiya, Y. Murakami, D.M. james, W. Chen, m. hackett, F. Yoshimura, D. R. Demuth, and R. J. Lamont., Short Fimbriae of Porphyromonas gingivalis and their role in coadhesion wih Streptococcus gordonii. Infection and Immunity, 2005. 73: p. 3983-3989.

12. Jenkinson, H.F.D., D.R., Structure, function and immunogenicity of streptococcal antigen I/II polypeptides. Mol. Microbiol., 1997. 23: p. 183-190.

13. Demuth, D.R., D.C. Irvine, J.W. Costerton, G.S. Cook, and R.J. Lamont., Discrete protein determinant directs the species-specific adherence of Porphyromonas gingivalis to oral streptococci. . Infection and Immunity, 2001. 69: p. 5736-5741.

14. Cook, G.S., J.W. Costerton, and R.J. Lamont., Biofilm formation by Porphyromonas gingivalis and Streptococcus gordonii. Journal of Periodontal Research, 1998. 33: p. 323-327.

15. Daep, C.A.L., R.J.; Demuth, D.R., Interaction of Porphyromonas gingivalis with Oral Streptococci Requires a Motif that resemles the Eukaryotic Nuclear Receptor Box Protein-Protein Interaction domain. Infection and Immunity, 2008. 76(7): p. 3273-3280.

16. Darimont, B.D.W., R.L.; Apriletti, J.W.; Stallcup, M.R.; Kushner, P.J.; Baxter, J.D.; Fletterick, R.J.; Yamamoto, K.R., Structure and specificity of nuclear receptor-coactivator interactions. Genes Dev., 1998. 12: p. 3343-3356.

17. He, B.W., E.M., Electrostatic modulation in steroid receptor recruitment of LXXLL and FXXLF motifs. Mol. Cell. Biol., 2003. 23: p. 2135-2150.

18. Kolb, H.C.F., M.G.; Sharpless, K.B., Click Chemistry: Diverse Chemical Function from a Few Good Reactions. Angew. Chem. Int. Ed. , 2001. 40: p. $2004-$ 2021.

19. Hein, C.D.L., X.; Wang, D., Click Chemistry, A Powerful Tool for Pharmaceutical Sciences. Pharmaceutical Research, 2008. 25(10): p. 2216-2230.

20. Kolb, H.C.S., K.B., The growing impact of click chemistry on drug discovery. DDT, 2003. 8(24): p. 1128-1137.

21. Forsgren, N.L., R.J.; Persson, K., Two Intramolecular Isopeptide Bonds are Identified in the Crystal Structure of teh Streptococcus gordonii SspB C-terminal Domain. Journal of Molecular Biology, 2010(397): p. 740-751. 
22. Butler, R.N.H., A.B.; King, W.B., Oxidations of some mono- and bis-(toluene-psulfonyl)hydrazones with mercury(II) and lead(IV) acetates: interception of hydrazono-metallo intermediates. Journal of the Chemical Society, 1978(8): p. 881-884.

23. Cutulic, S.P.Y.F., N.J.; Zhou, S.; Chrystal, E.J.T.; Murphy, J.A., Metal-Free Reductive Cleavage of $\mathrm{C}-\mathrm{O} \sigma$-bonds in Acyloin Derivatives by an Organic Neutral Super-Electron-Donor. Journal of Organic Chemistry, 2009. 74(22): p. 87138718.

24. Strzybny, P.P.E.V.E., T.; Backeberg, O.G., Reaction of a-acyloxyketones with ammonium acetate. Journal of the South African Chemical Institute 1969. 22(3): p. 158-164.

25. Davidson, D.W., M.; Jelling, M., The Action of Ammonia on Benzoin. The Journal of Organic Chemistry, 1937. 2(4): p. 328-334.

26. Huisgen, R.R., R., New 1,3-dipolar cycloadditions of nitrile ylides and tautomerism of imidochlorides. Tetrahedron Letters, 1966(6): p. 649-654.

27. Goddar-Borger, E.D.S., R.V., An Efficient, Inexpensive, and Shelf-Stable Diazotransfer Reagent: Imidazole-1-sulfonyl Azide Hydrochloride. Organic Letters, 2007. 9(19): p. 3797-3800.

28. Boyer, J.H.E., S.E.; , Reduction of the azido group with sodium borohydride. Journal of Organic Chemistry, 1958. 23: p. 127-129. 
APPENDIX I

TABLE OF CONTENTS

PAGE

ABSTRACT

ACKNOWLEDGEMENTS

DEDICATION

LIST OF FIGURES

LIST OF SCHEMES

iii

iv

$\mathrm{v}$

vi

vii

INTRODUCTION

SCHEMES

RESULTS

METHODS

DISCUSSION

REFERENCES

APPENDIX (I) TABLE OF CONTENTS

APPENDIC (II) ABBREVIATIONS

APPENDIX (III) SPECTRA

CURRICULUM VITAE 


\section{APPENDIX II}

\section{ABBREVIATIONS}

$\begin{array}{ll}{ }^{13} \mathrm{C} & \text { Carbon Nucleaus } \\ \mathrm{CH}_{2} \mathrm{Cl}_{2} & \text { Dichloromethane } \\ \mathrm{CHCl} 3 & \text { Chloroform } \\ { }^{1} \mathrm{H} & \text { Proton Nucleus } \\ { }_{\mathrm{MCPBA}} & \text { 3-Chloroperbenzoic acid } \\ { }_{\mathrm{NMR}} & \text { Nuclear Magnetic Resonance } \\ { }_{\mathrm{R}} & \text { Retention factor } \\ \text { TLC } & \text { Thin-layered chromatography }\end{array}$



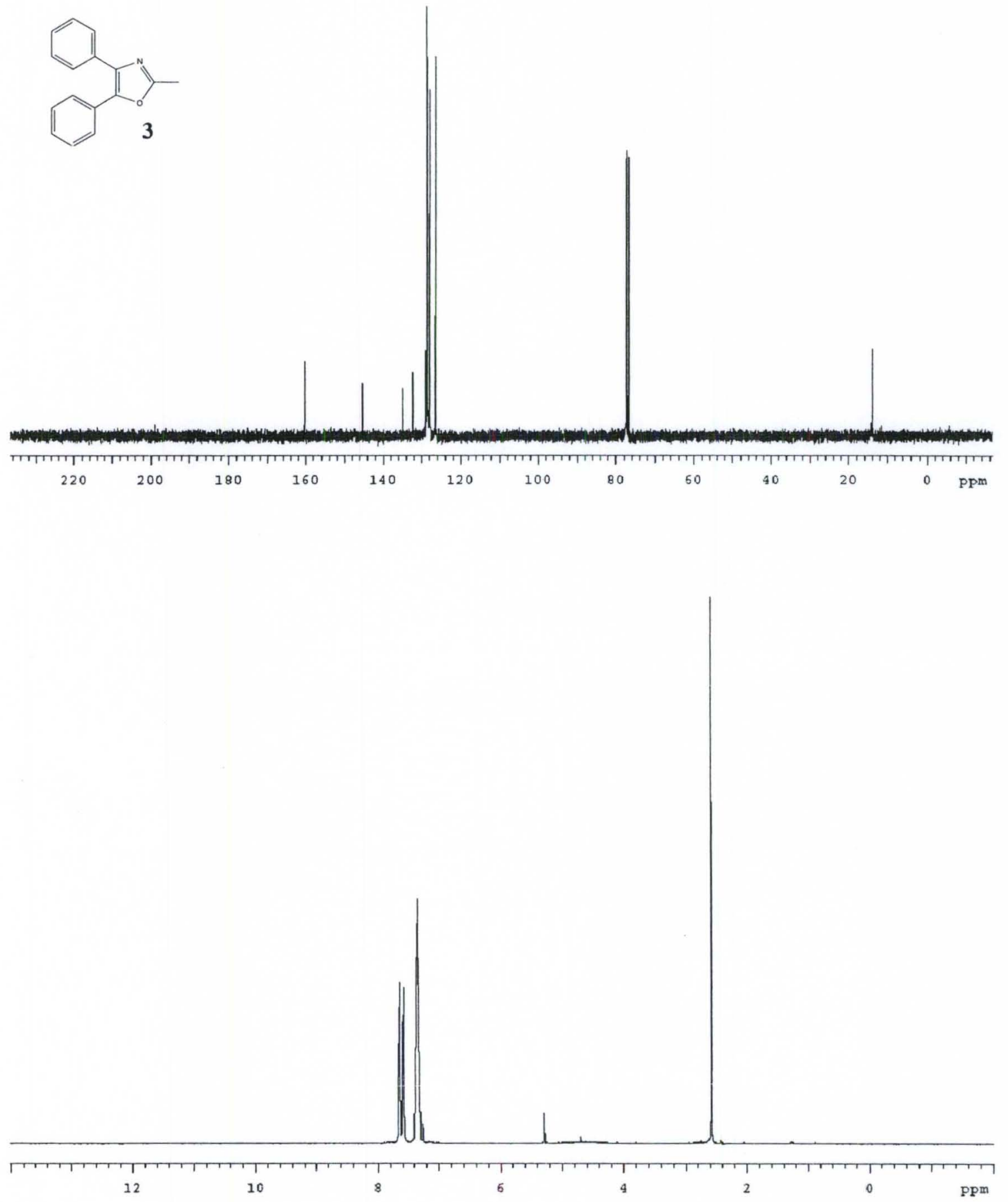

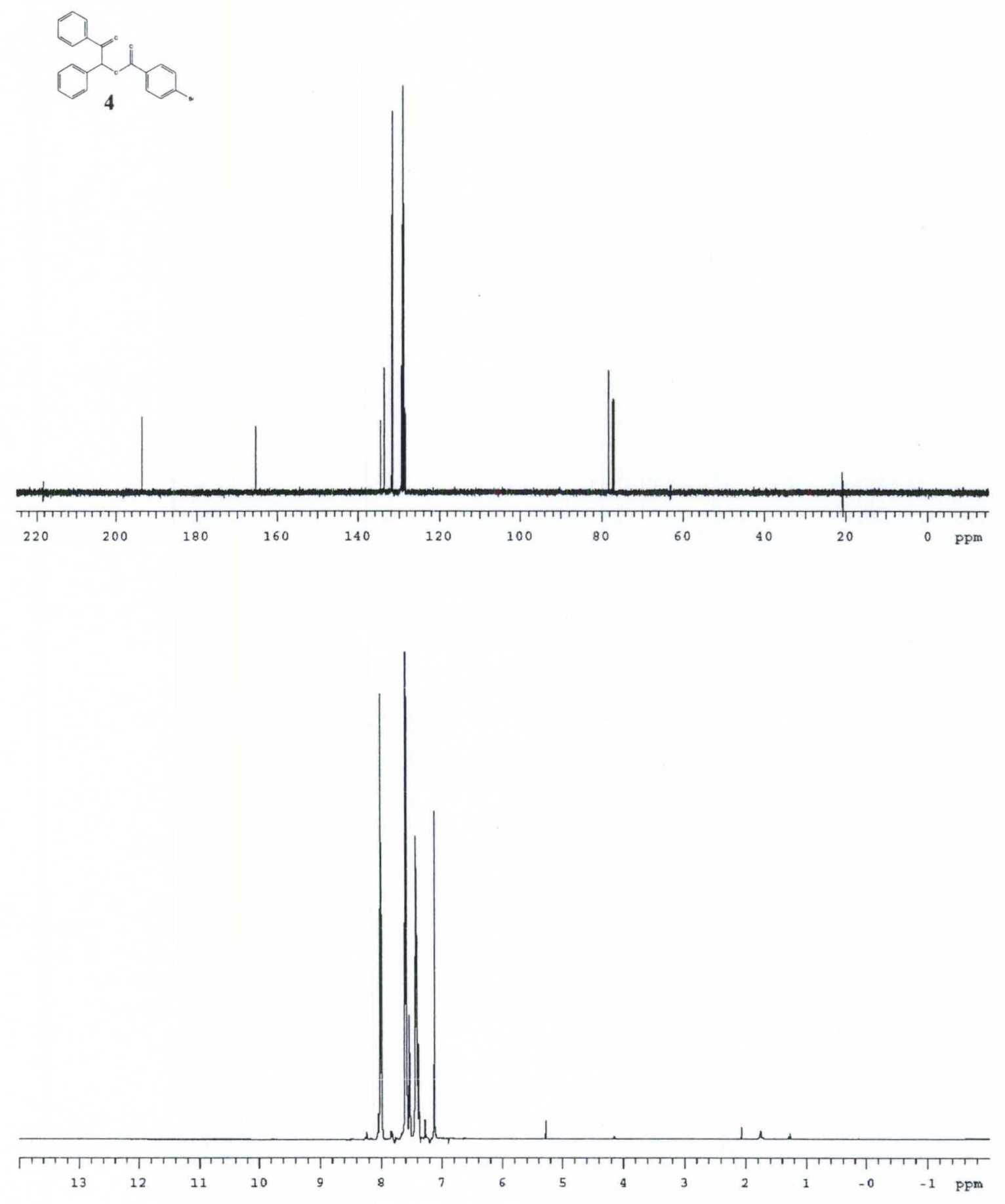

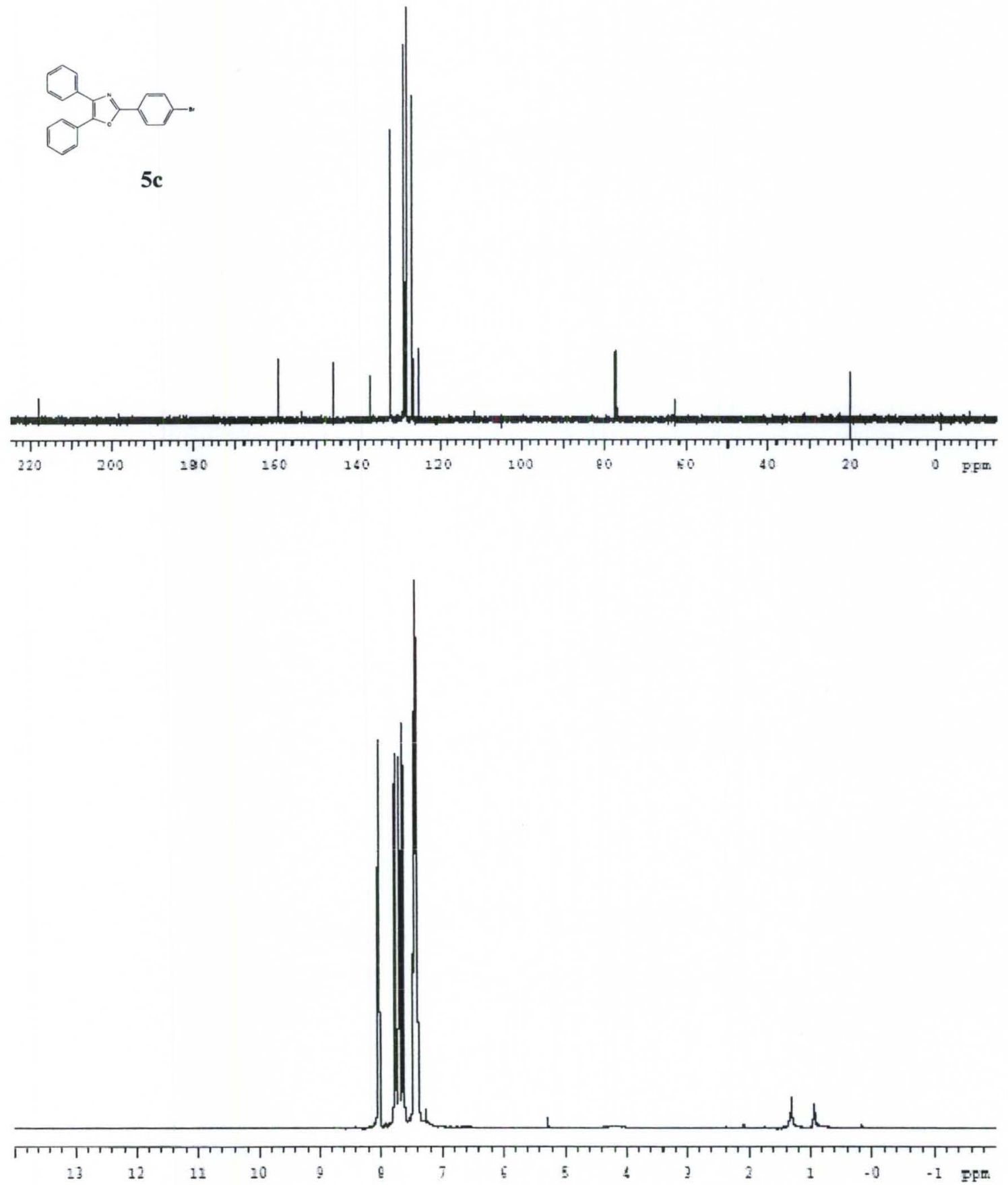

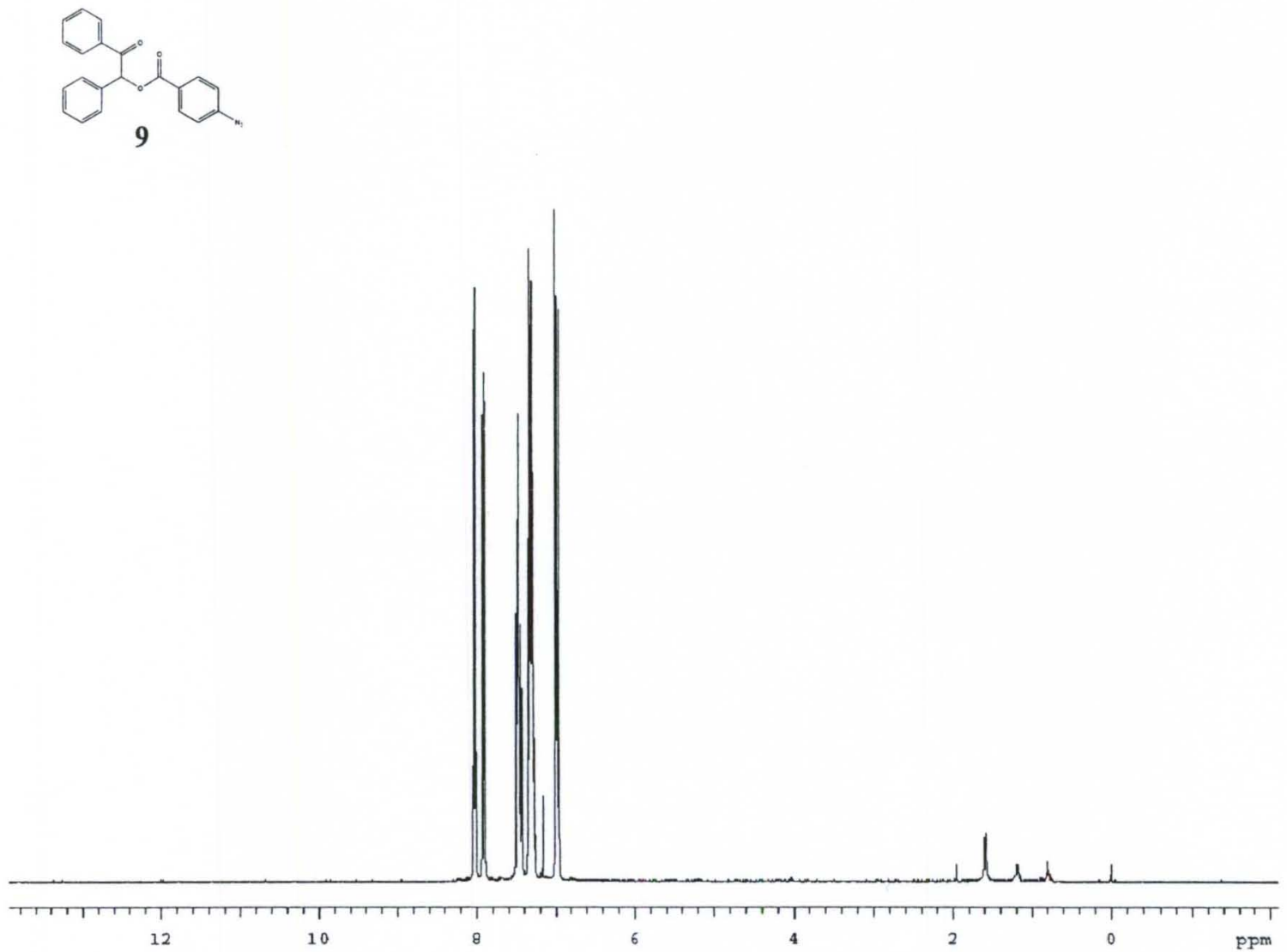

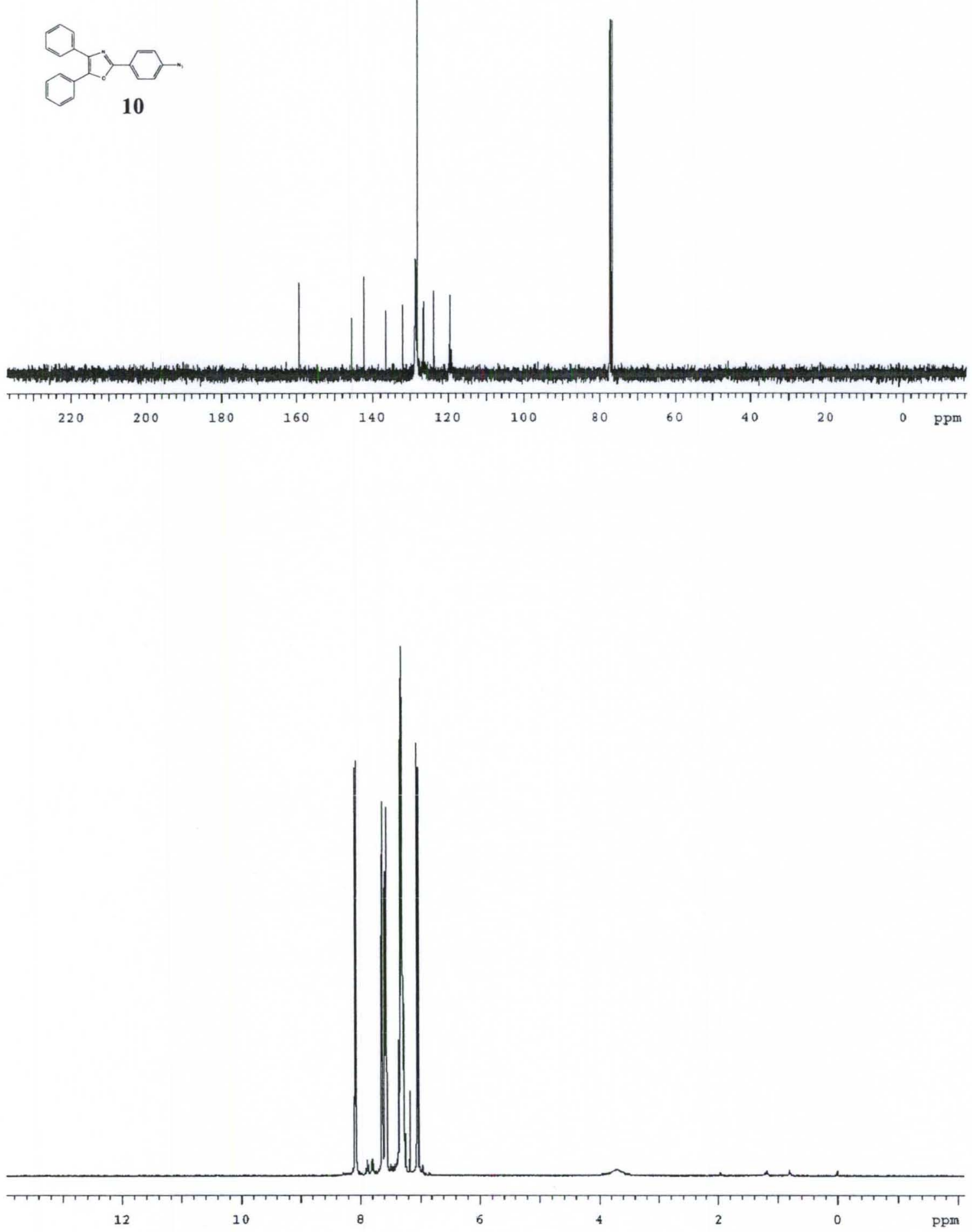

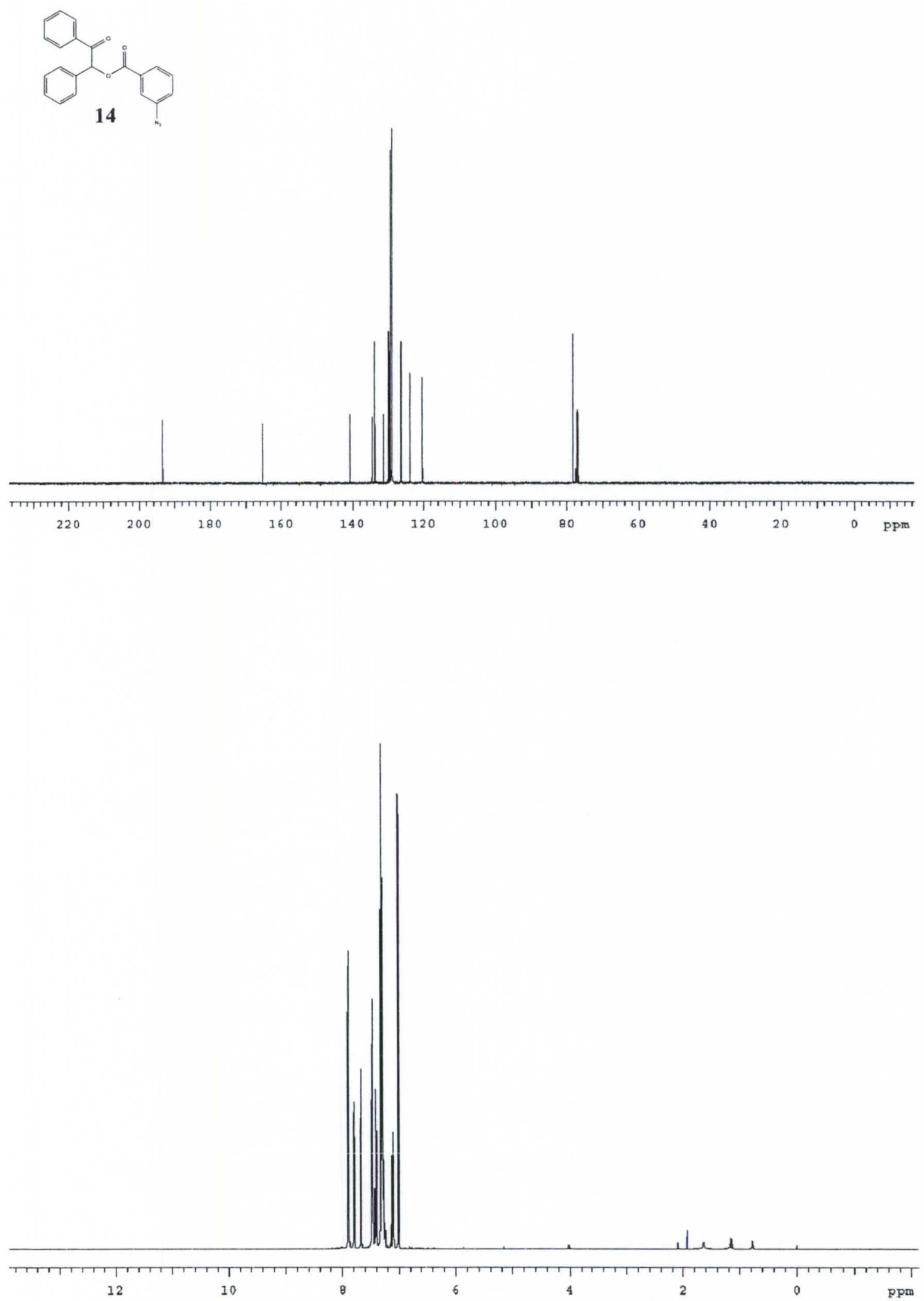

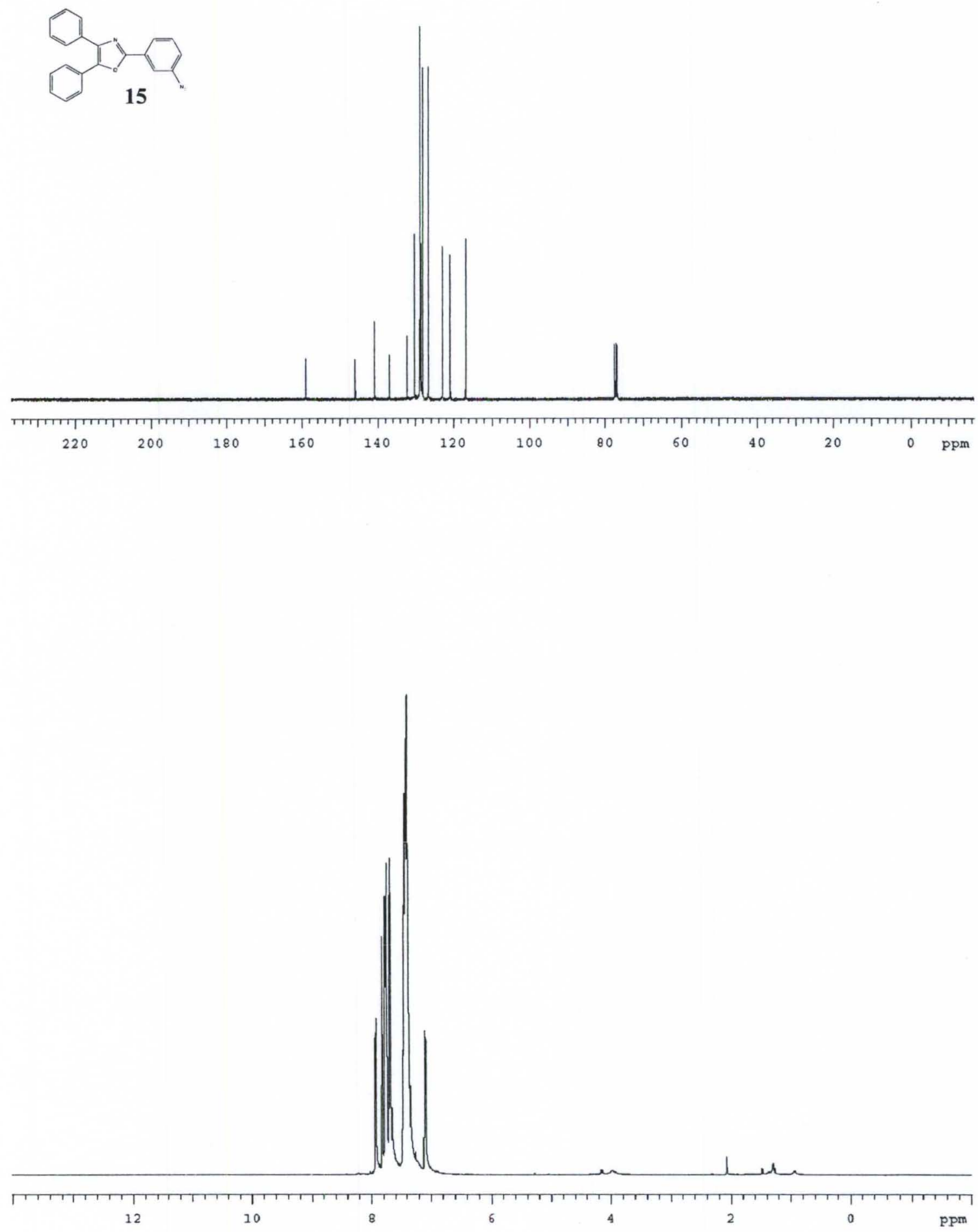

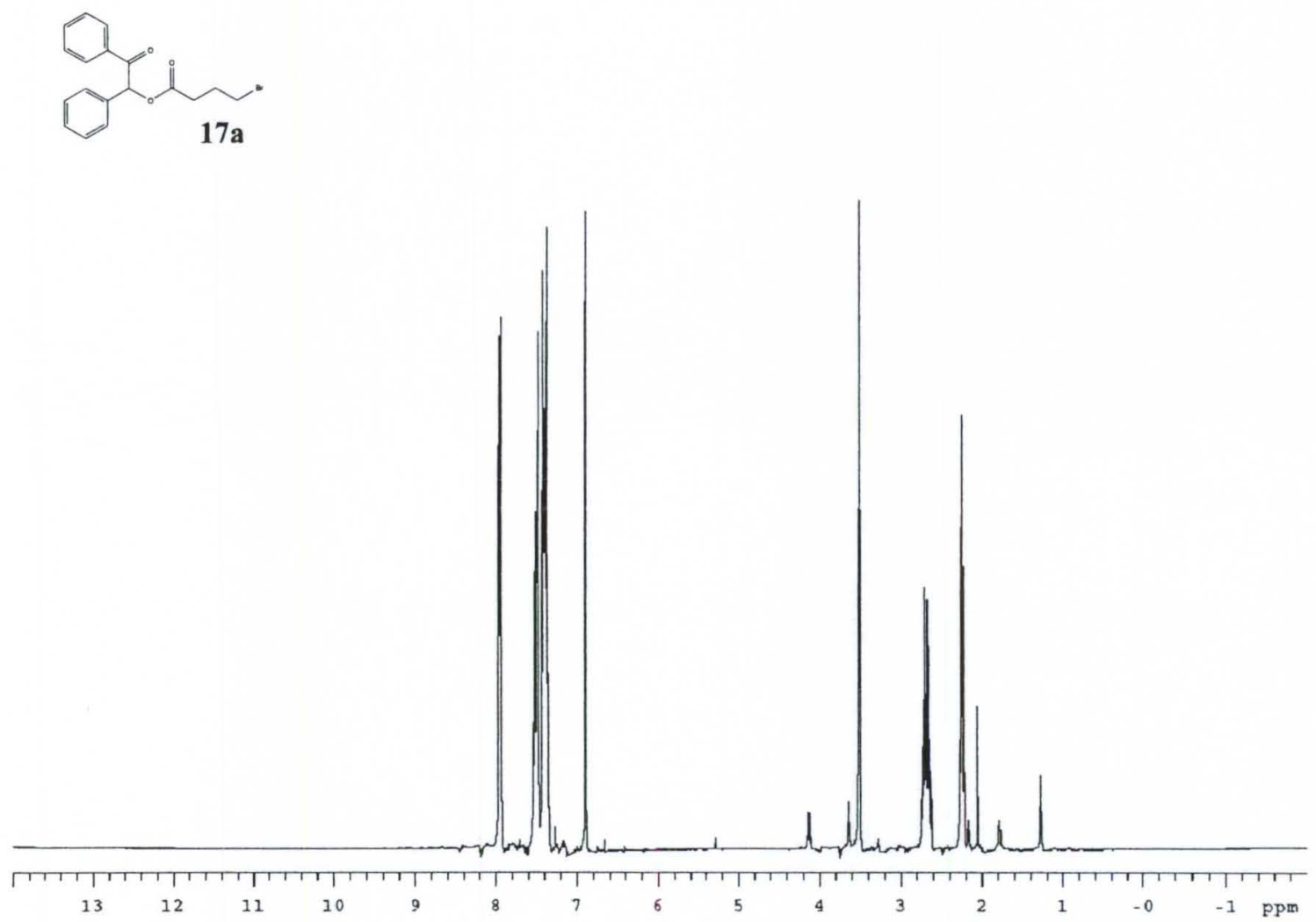

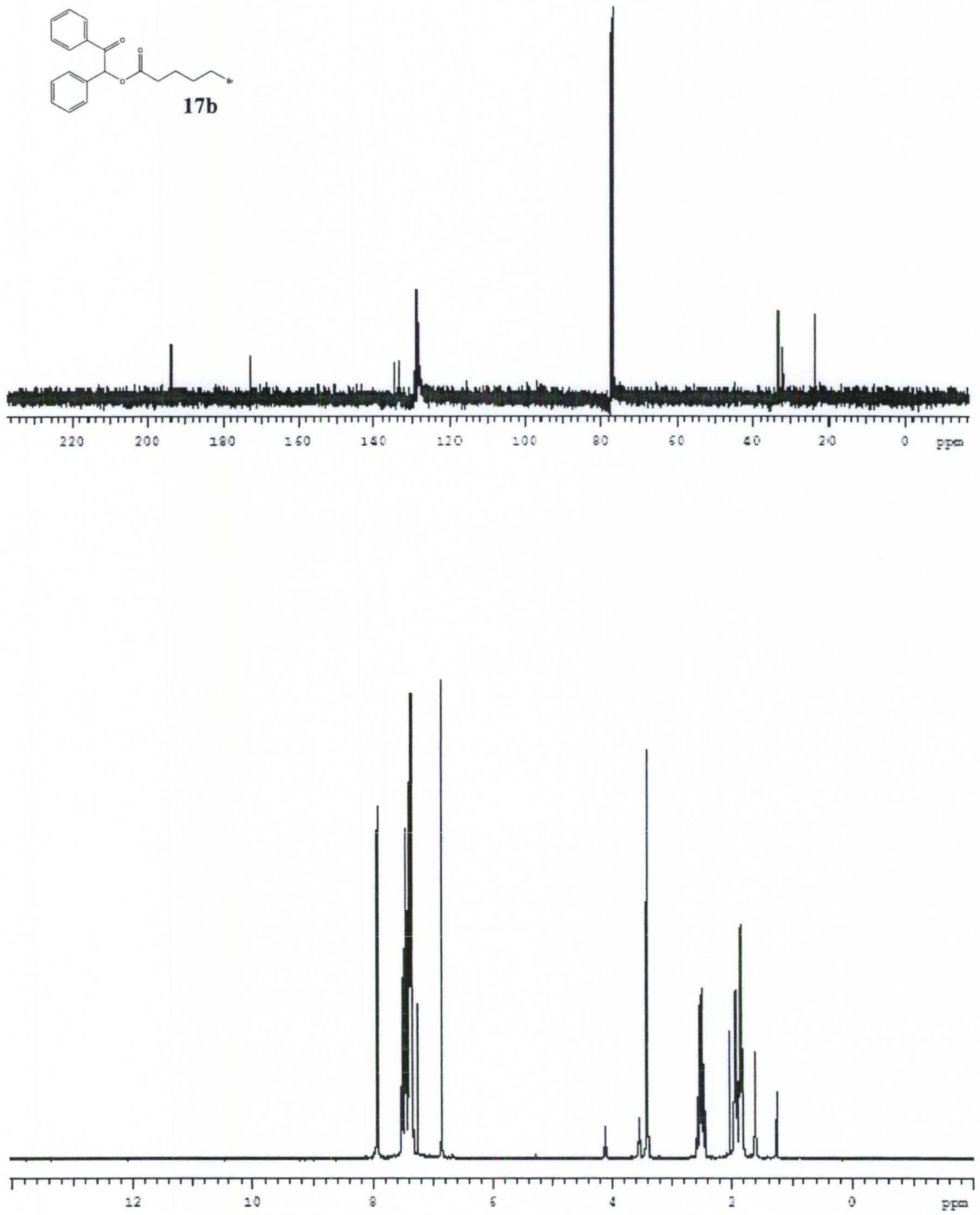

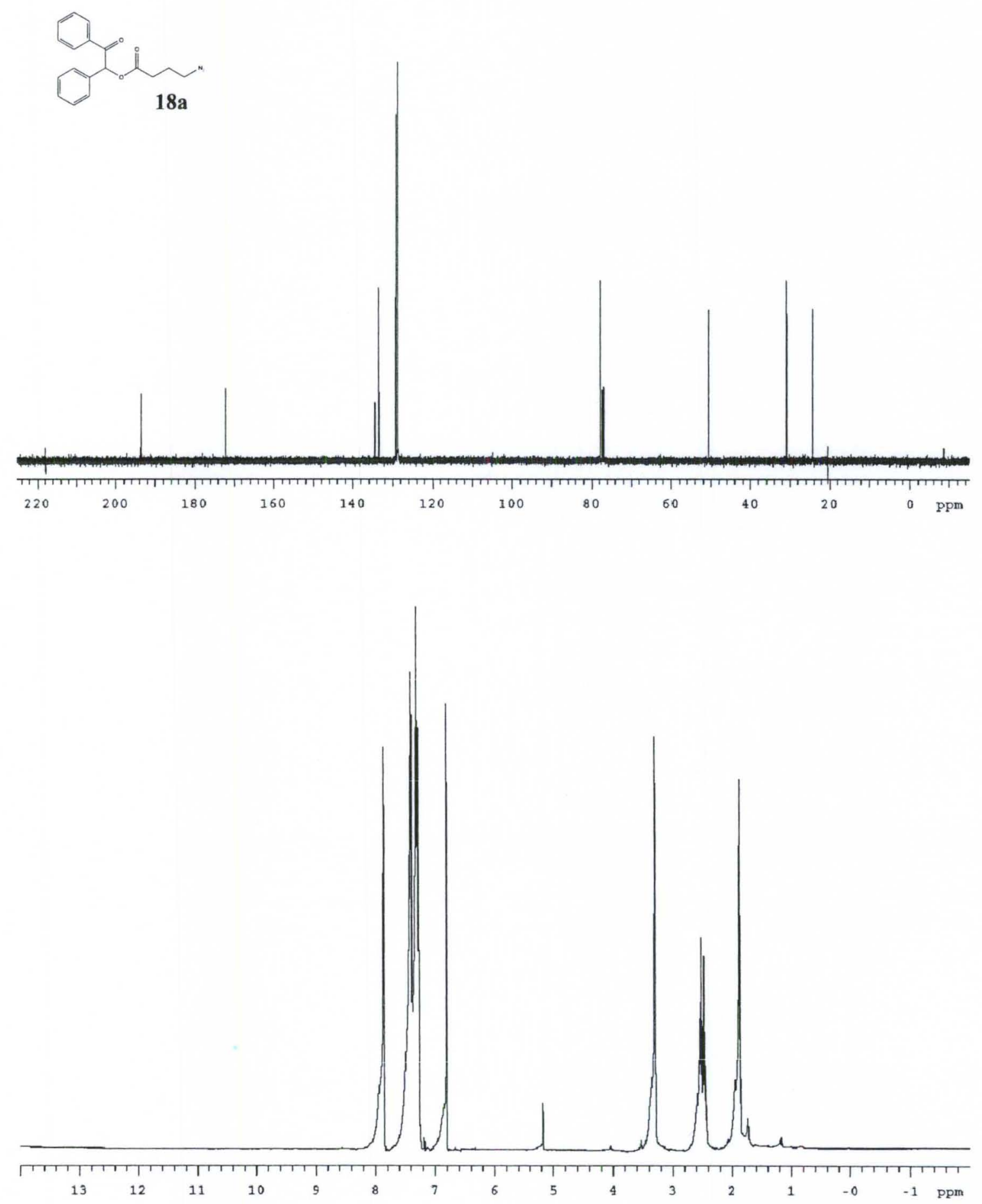

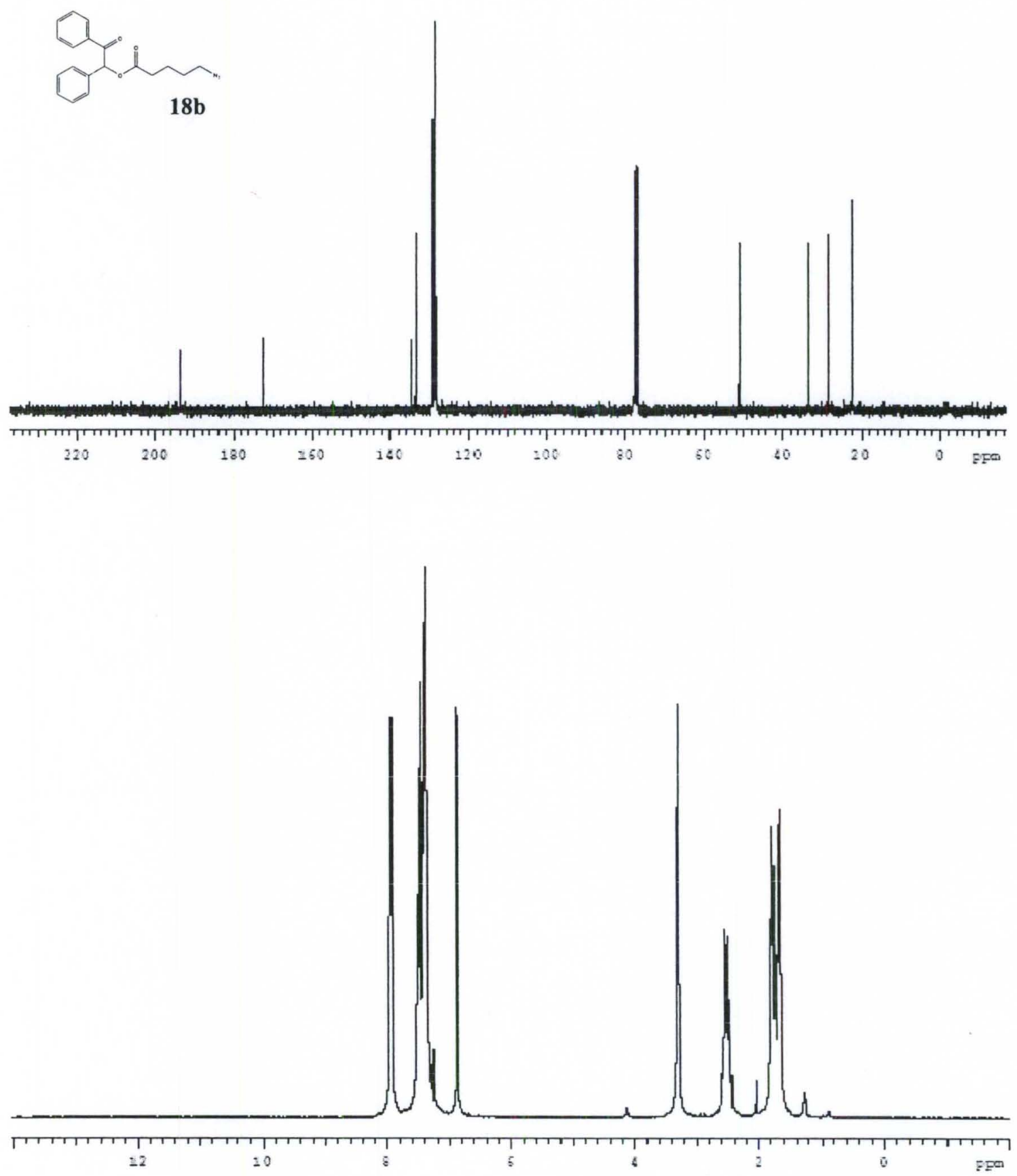

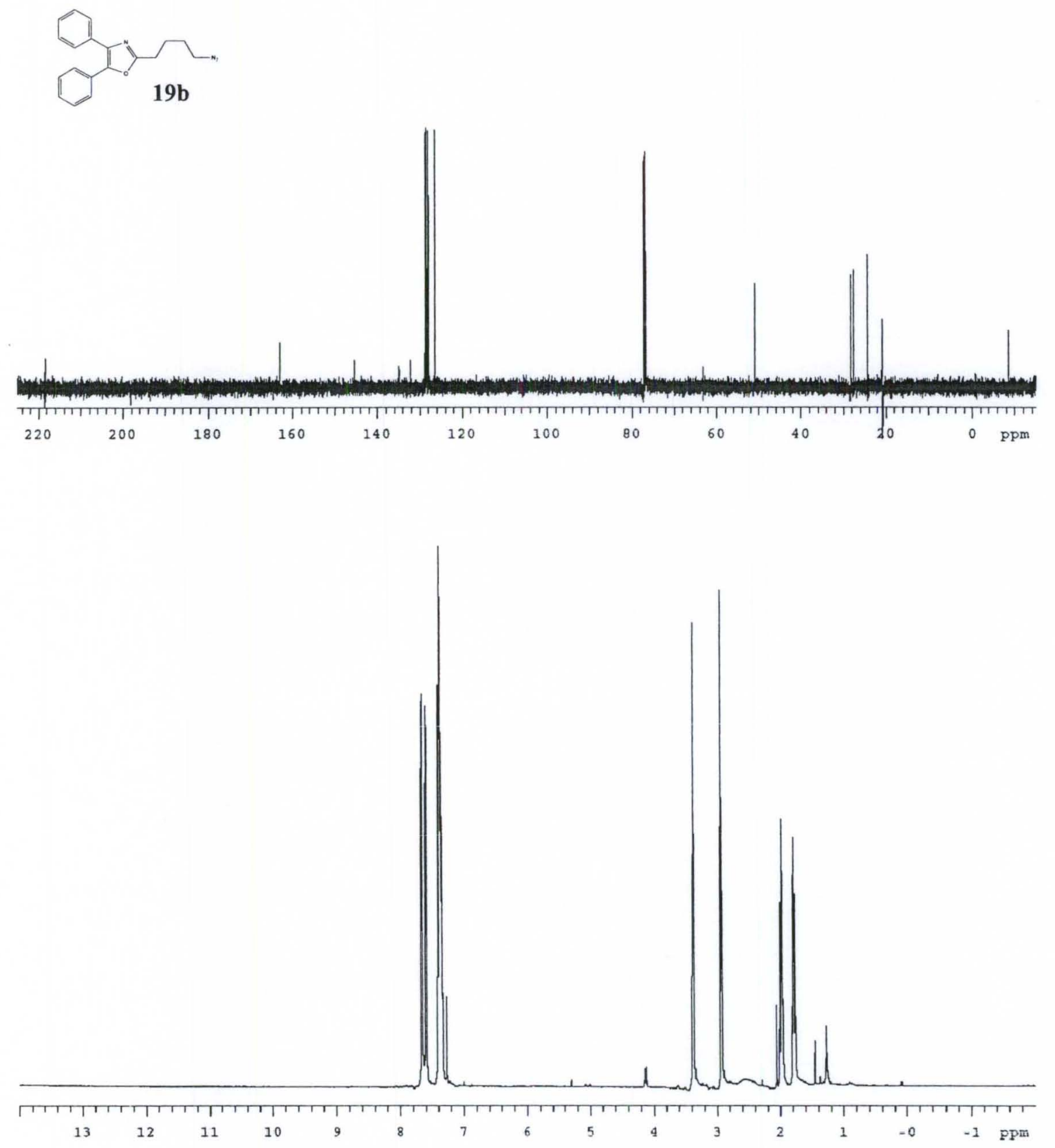

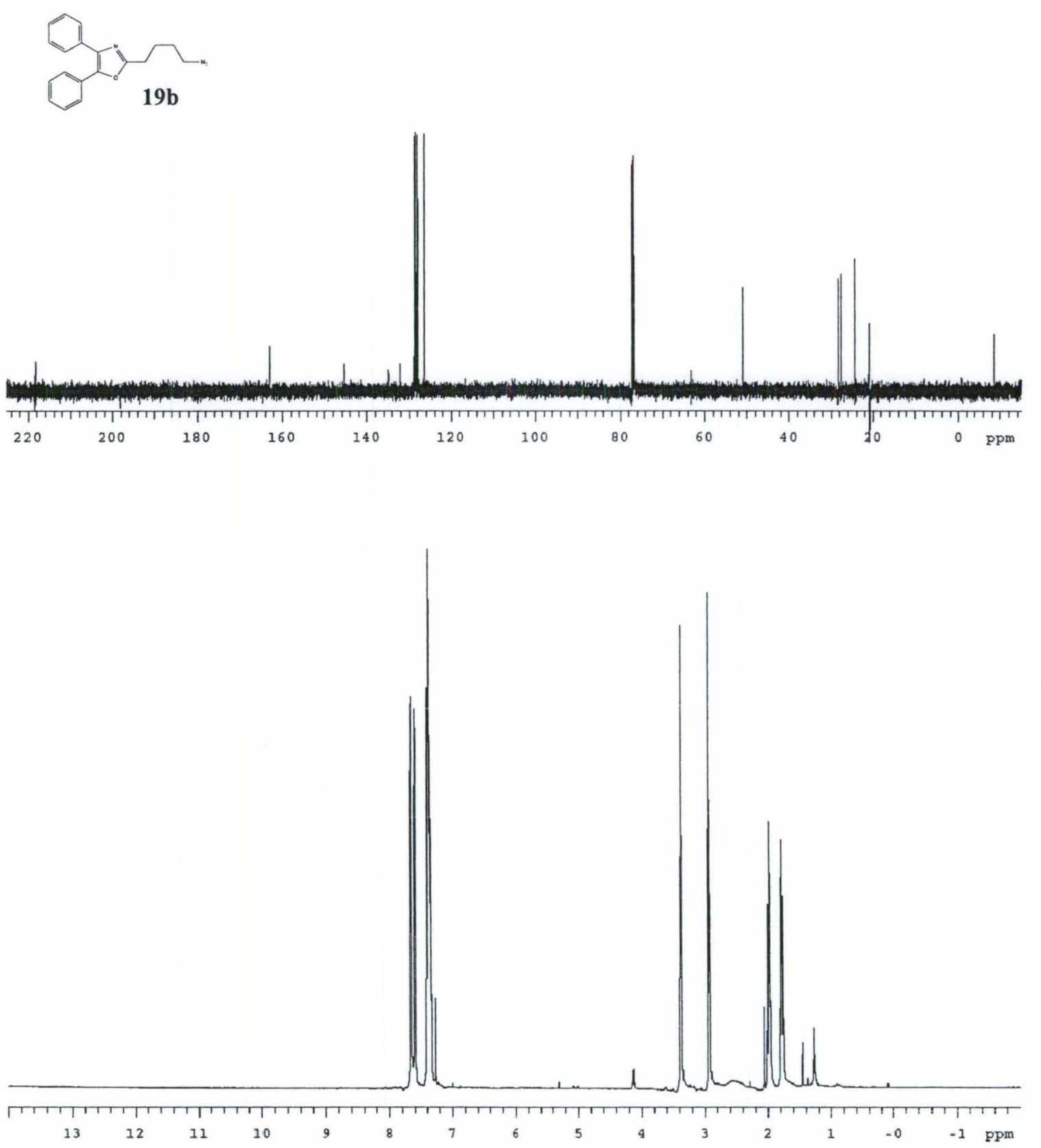

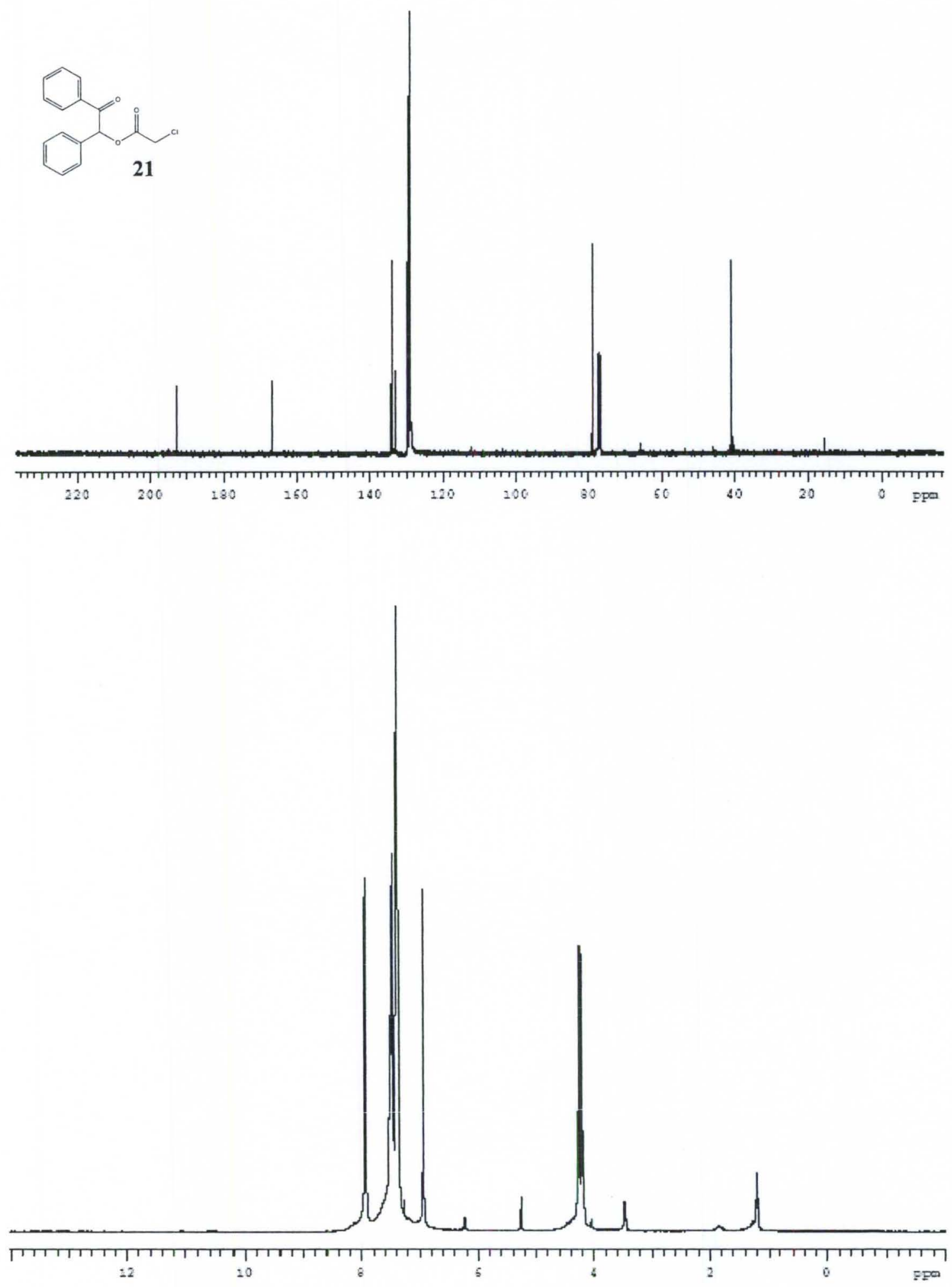

50 

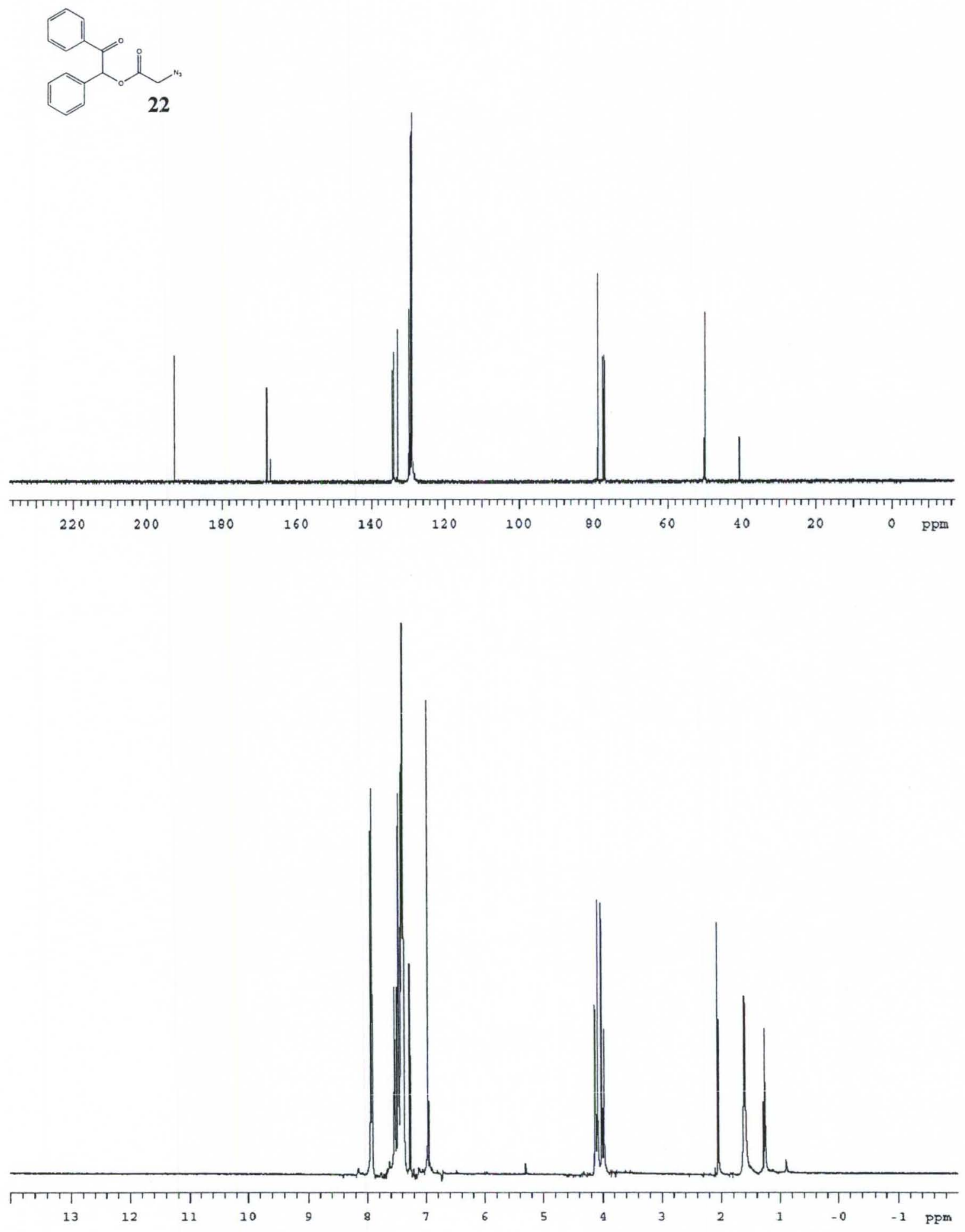

51 

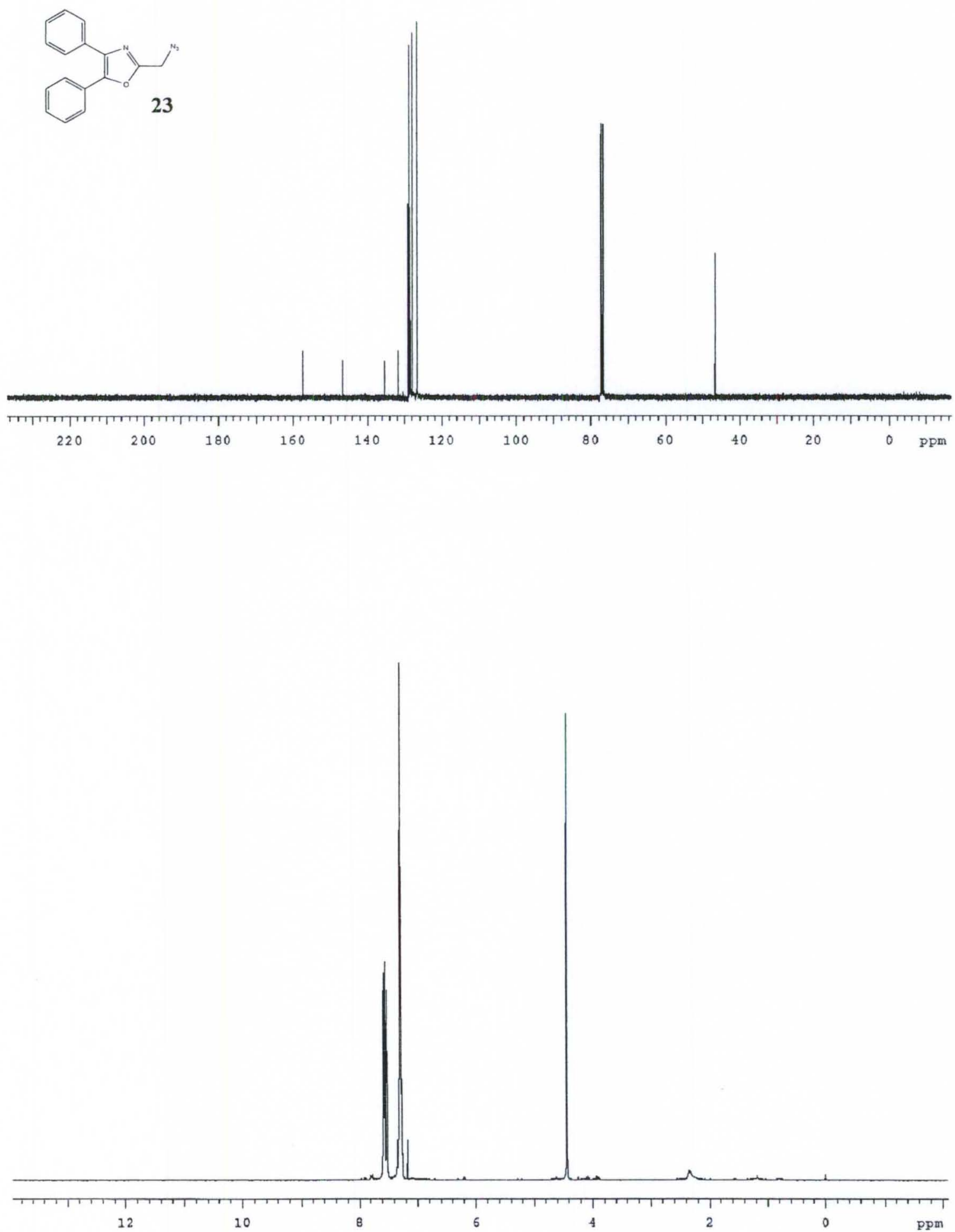

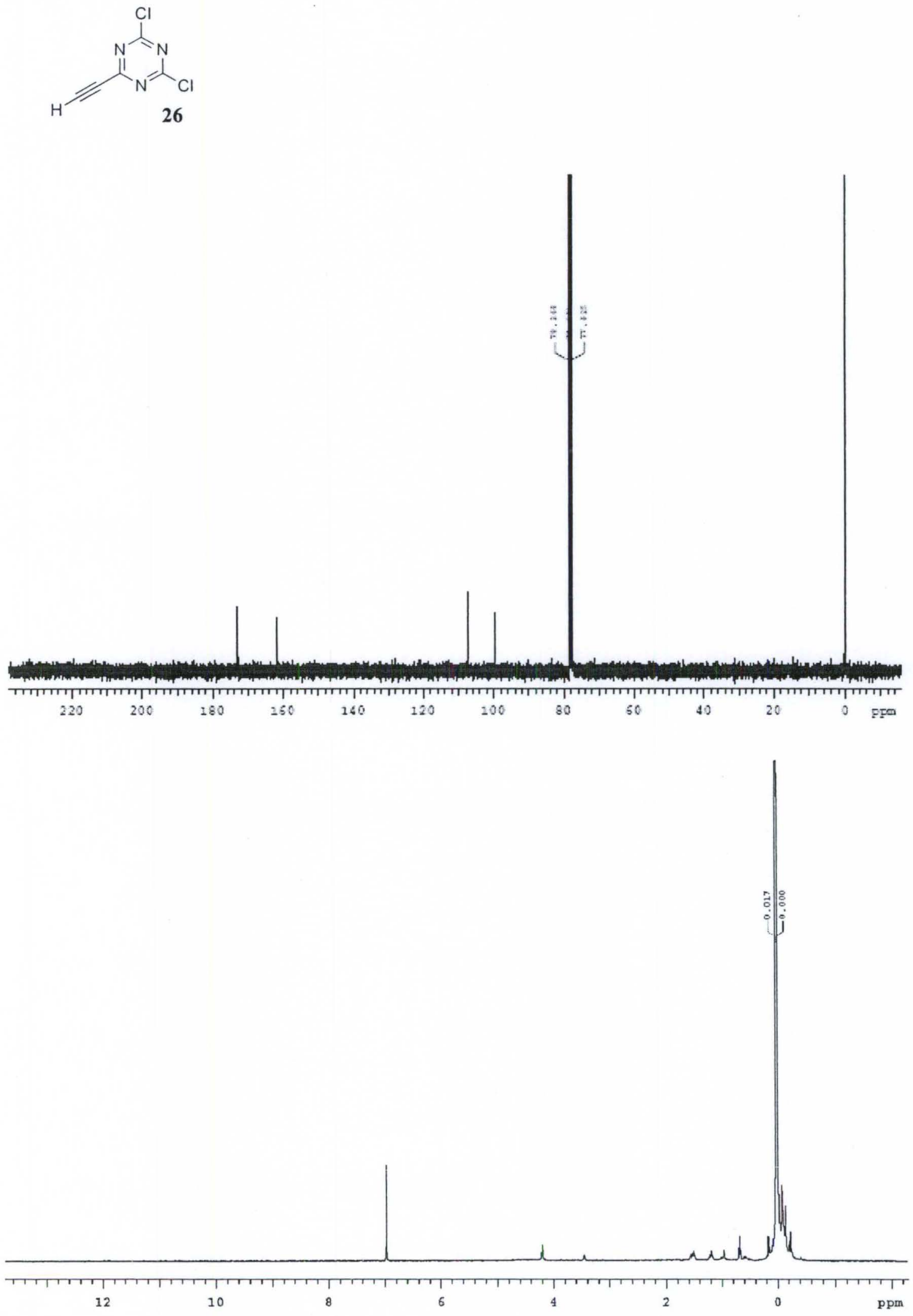


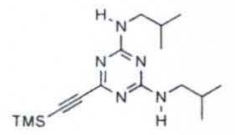

27
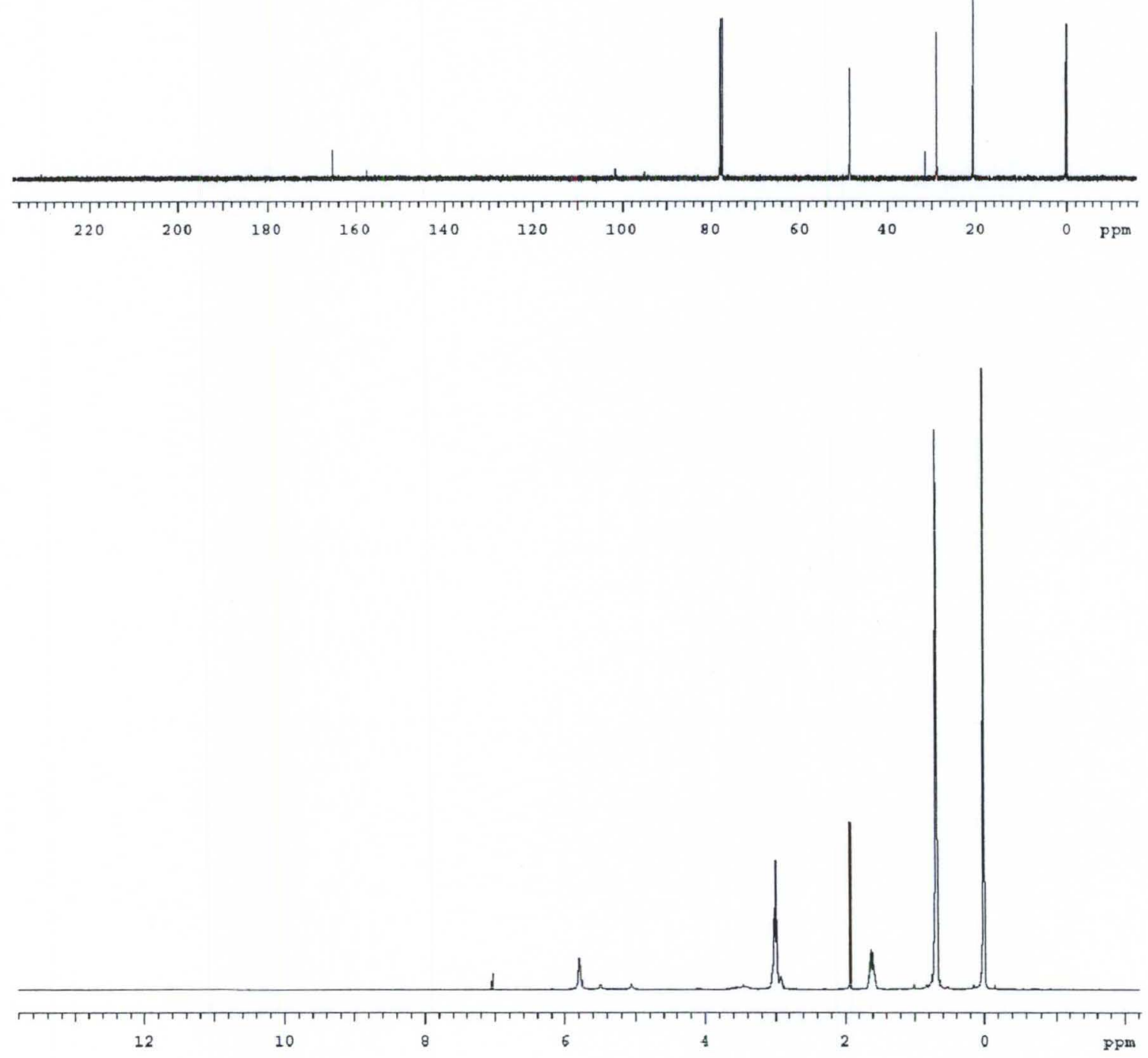


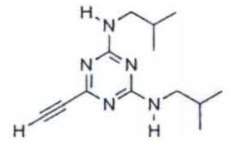

28

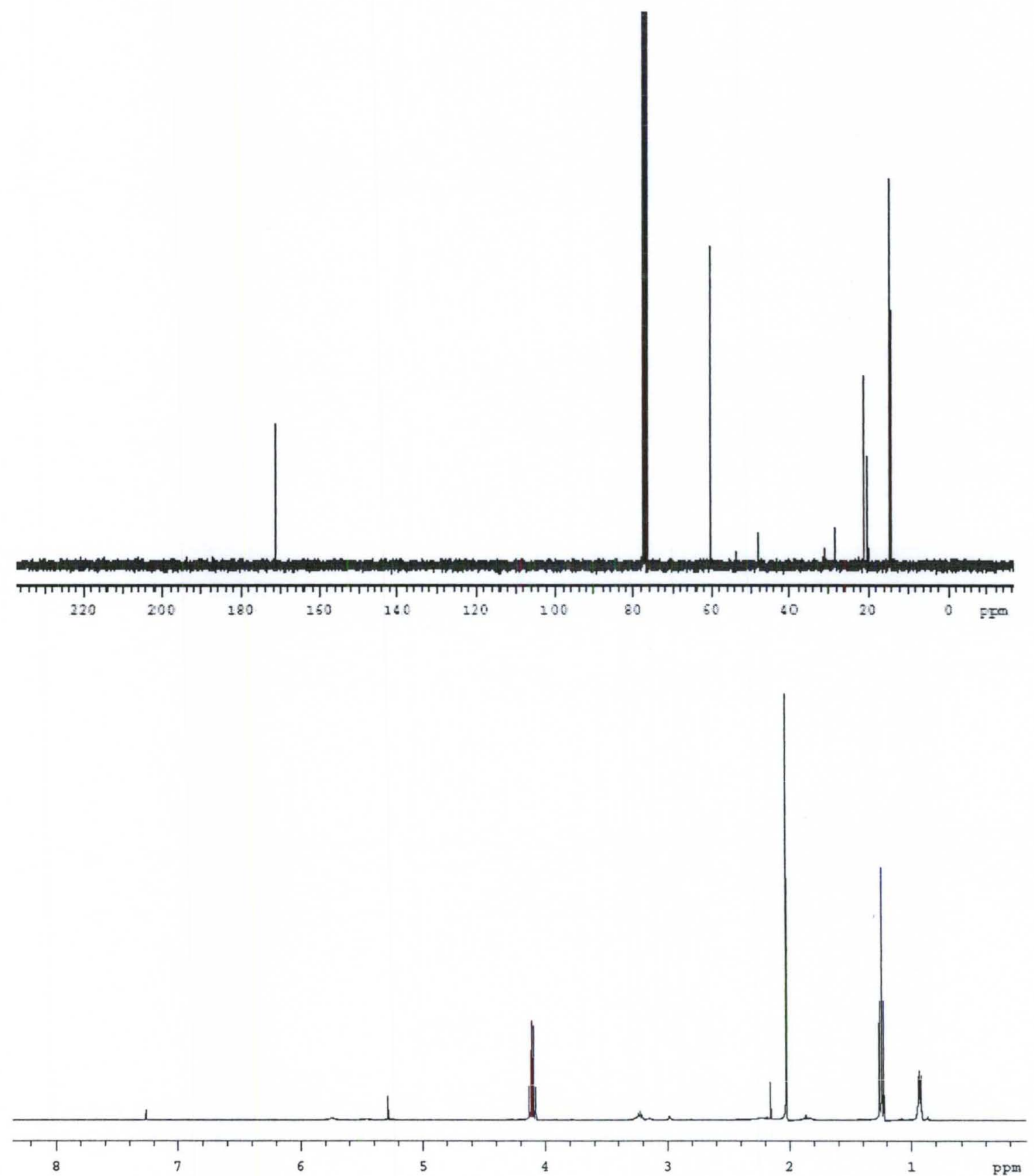



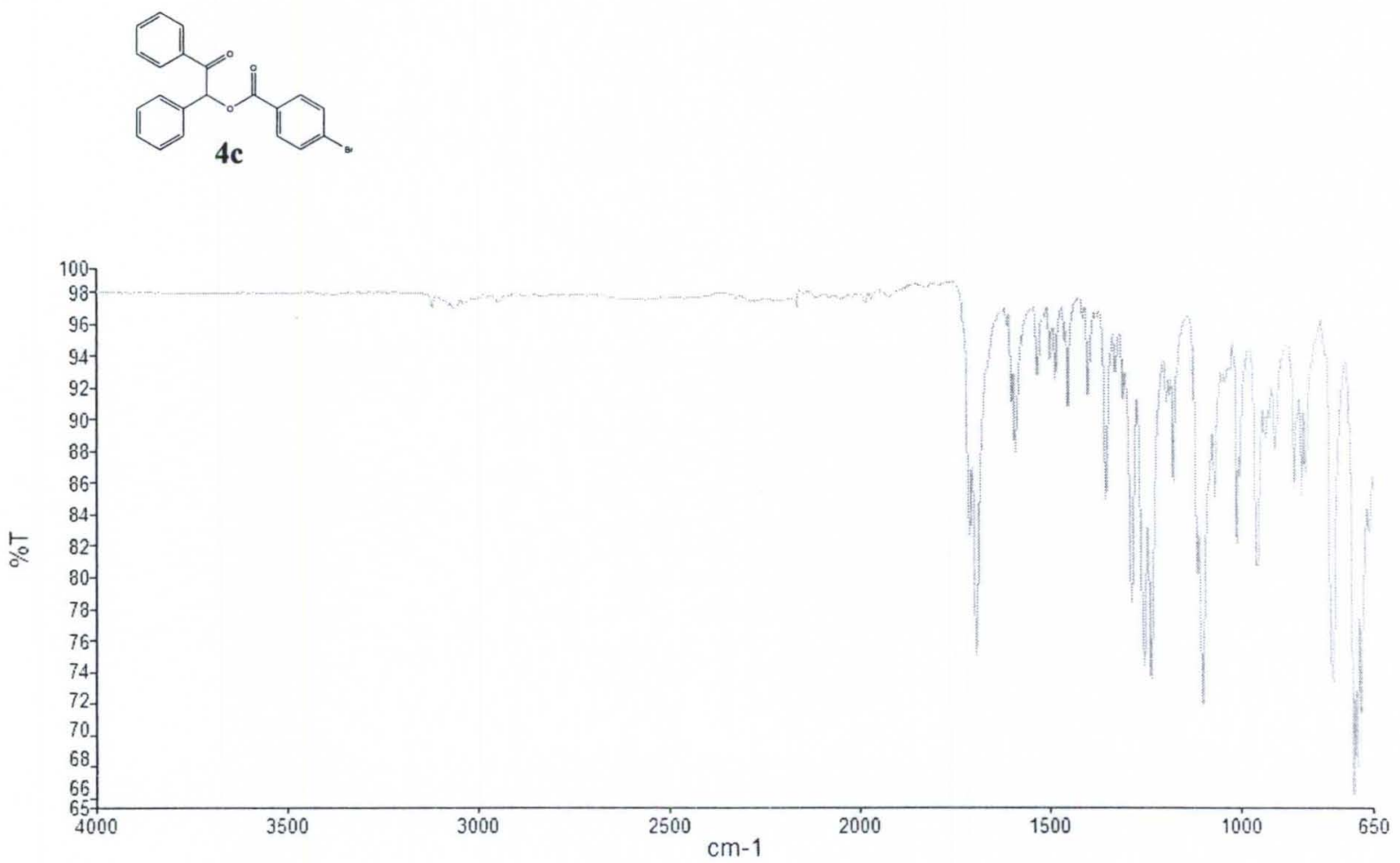

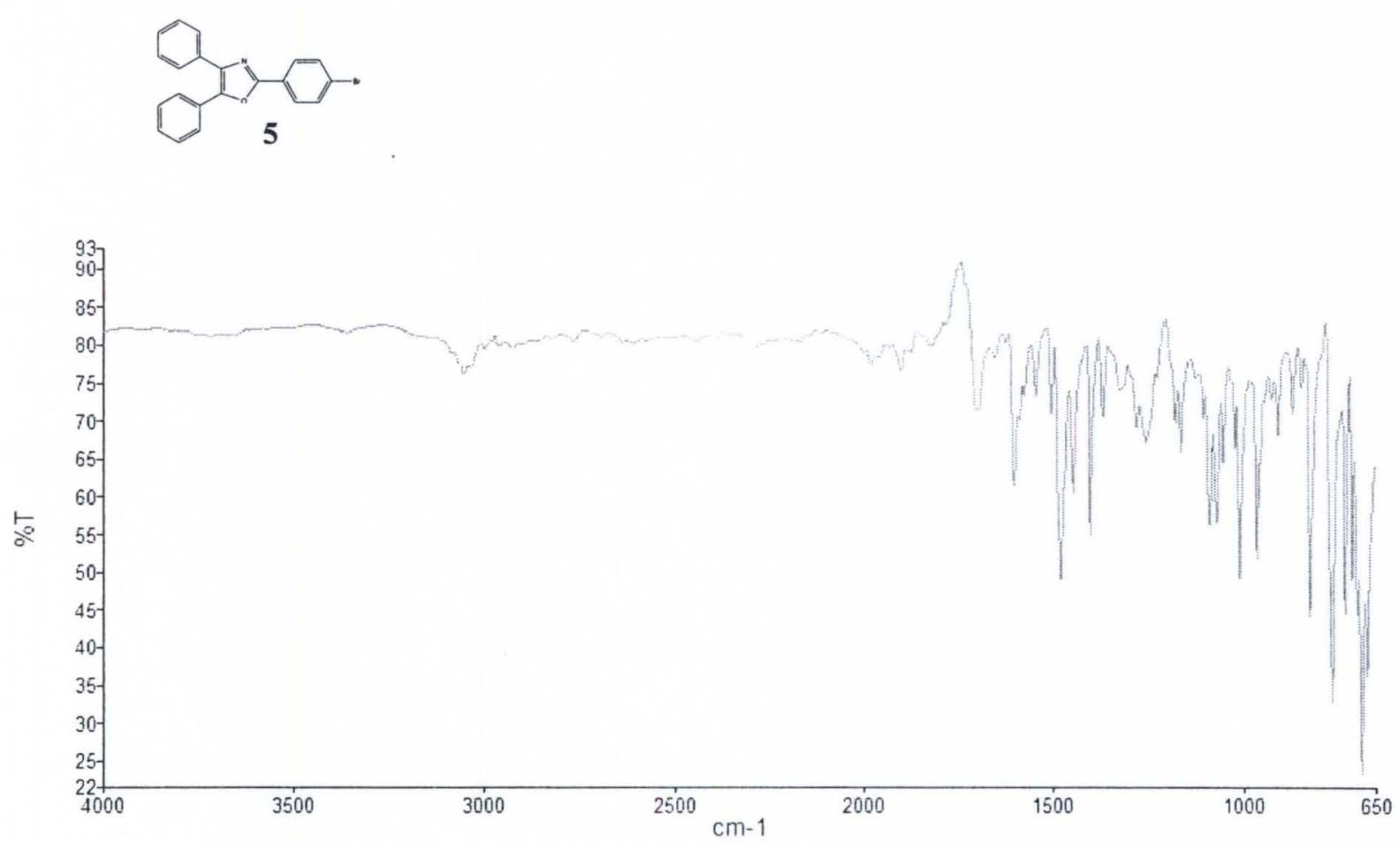

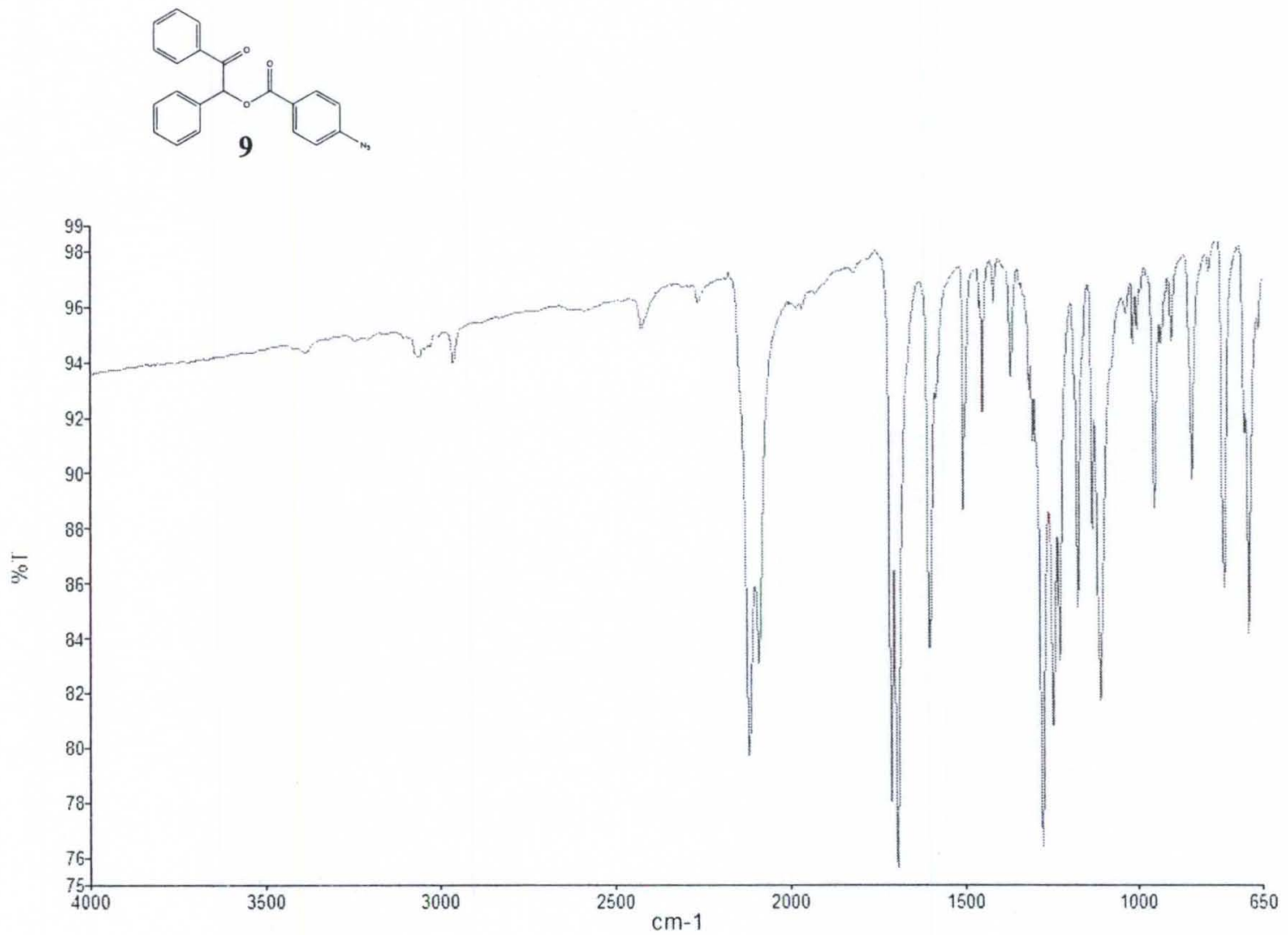

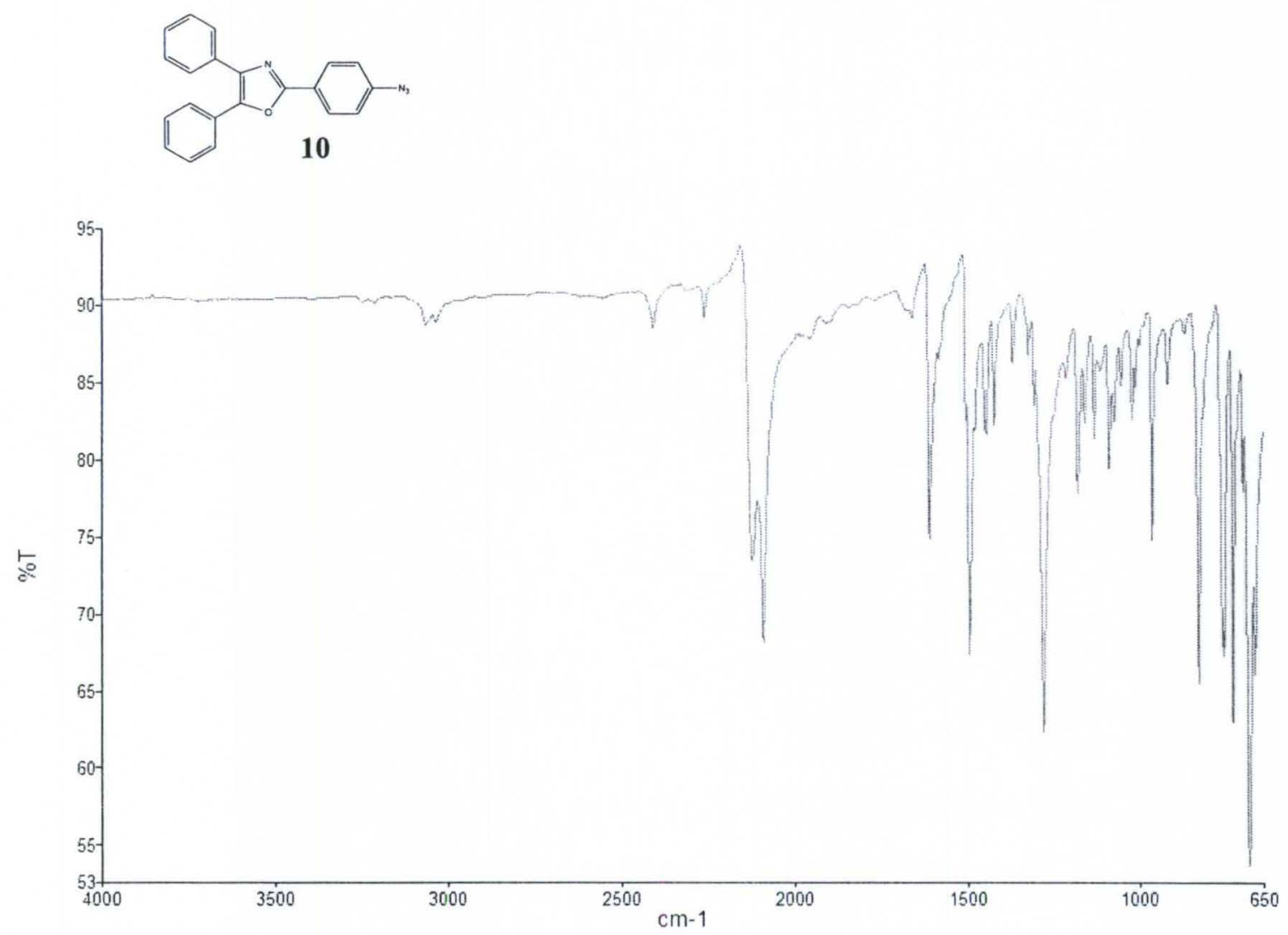

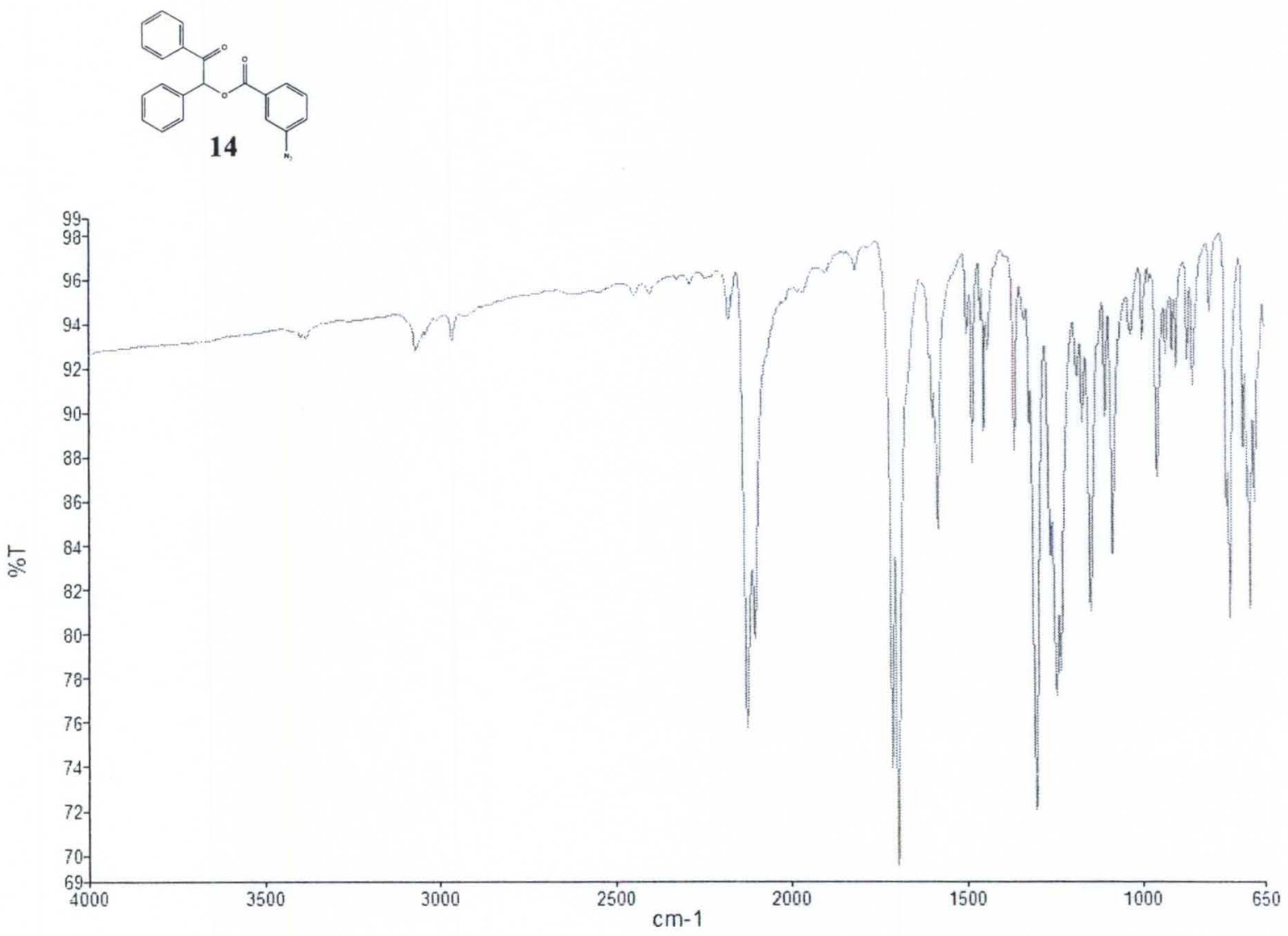

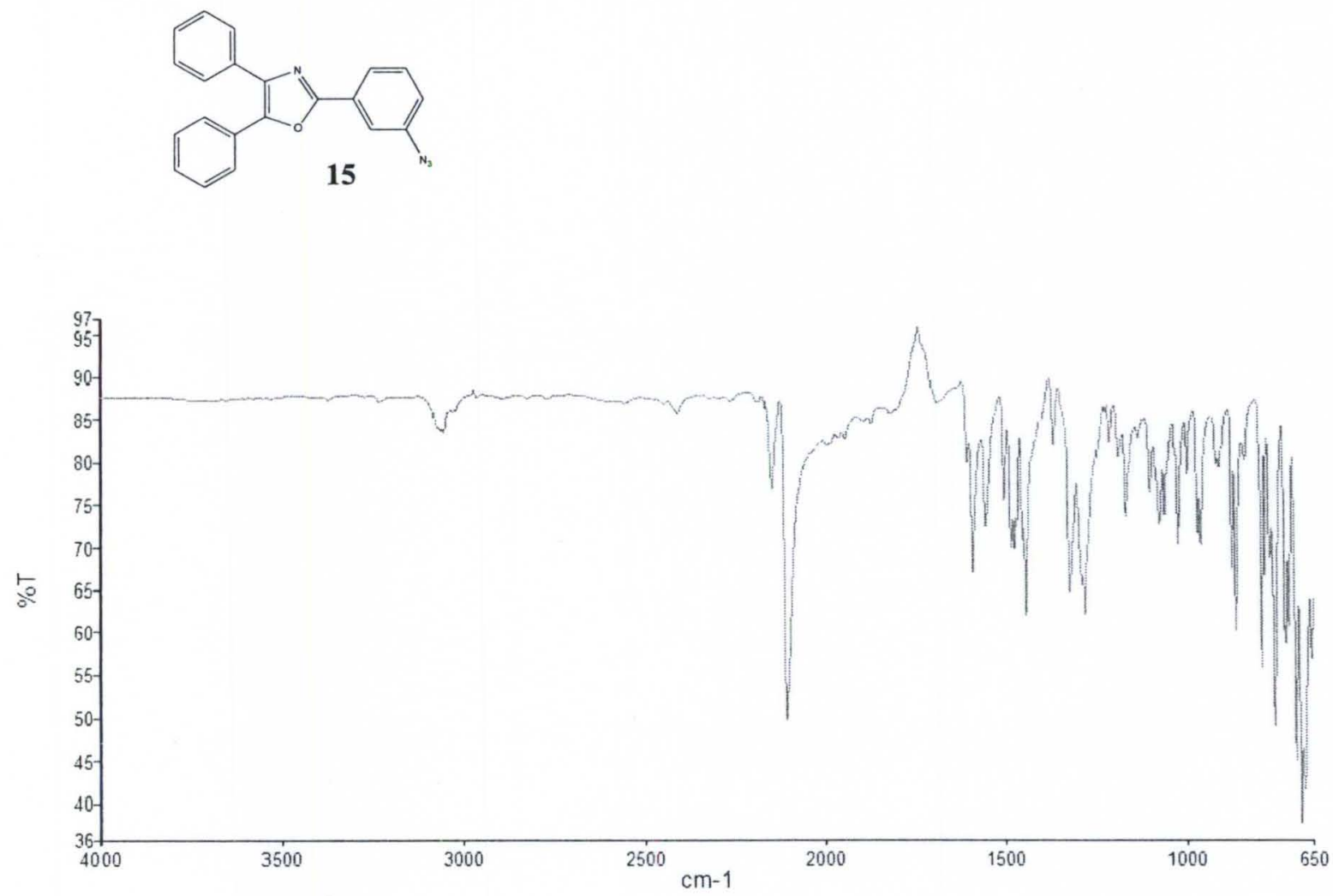

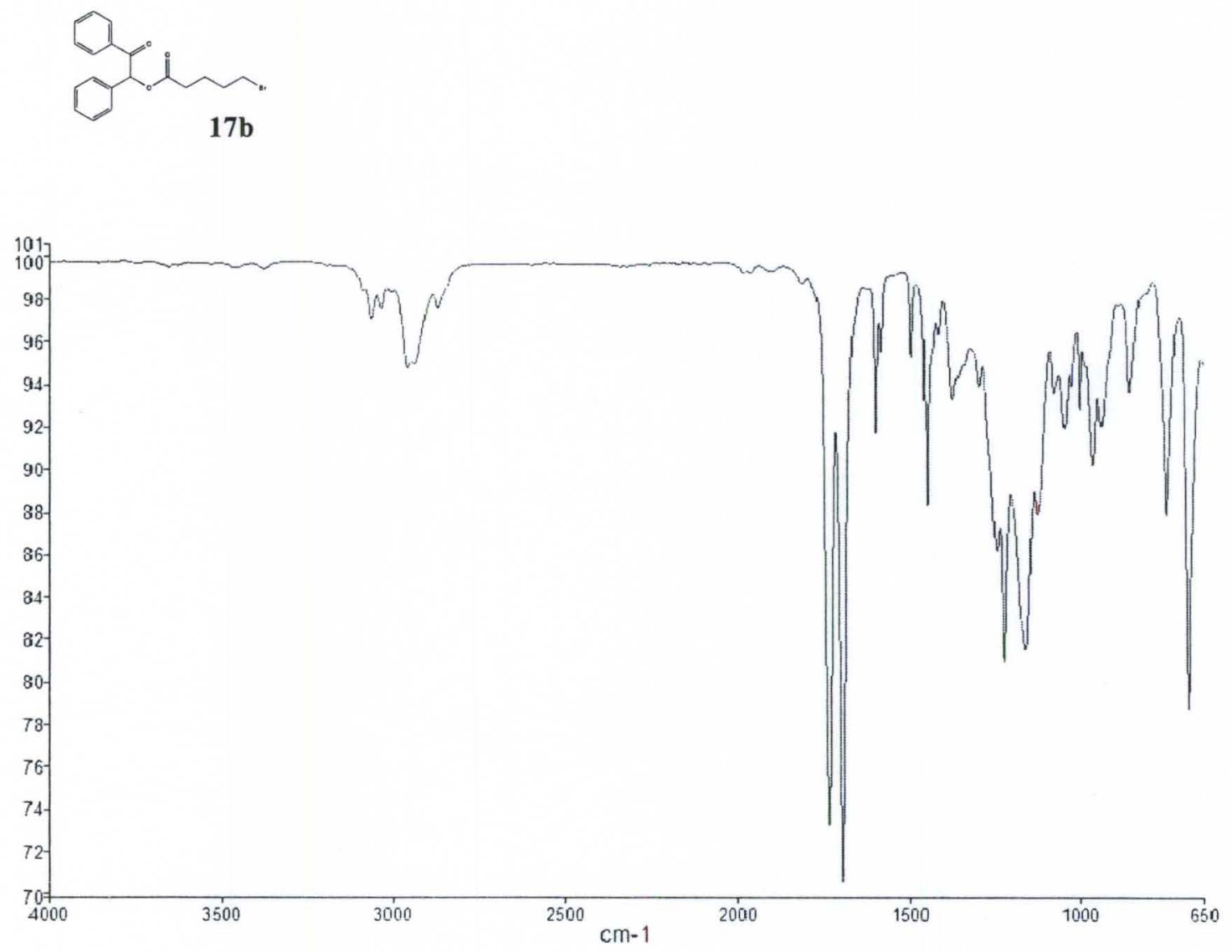

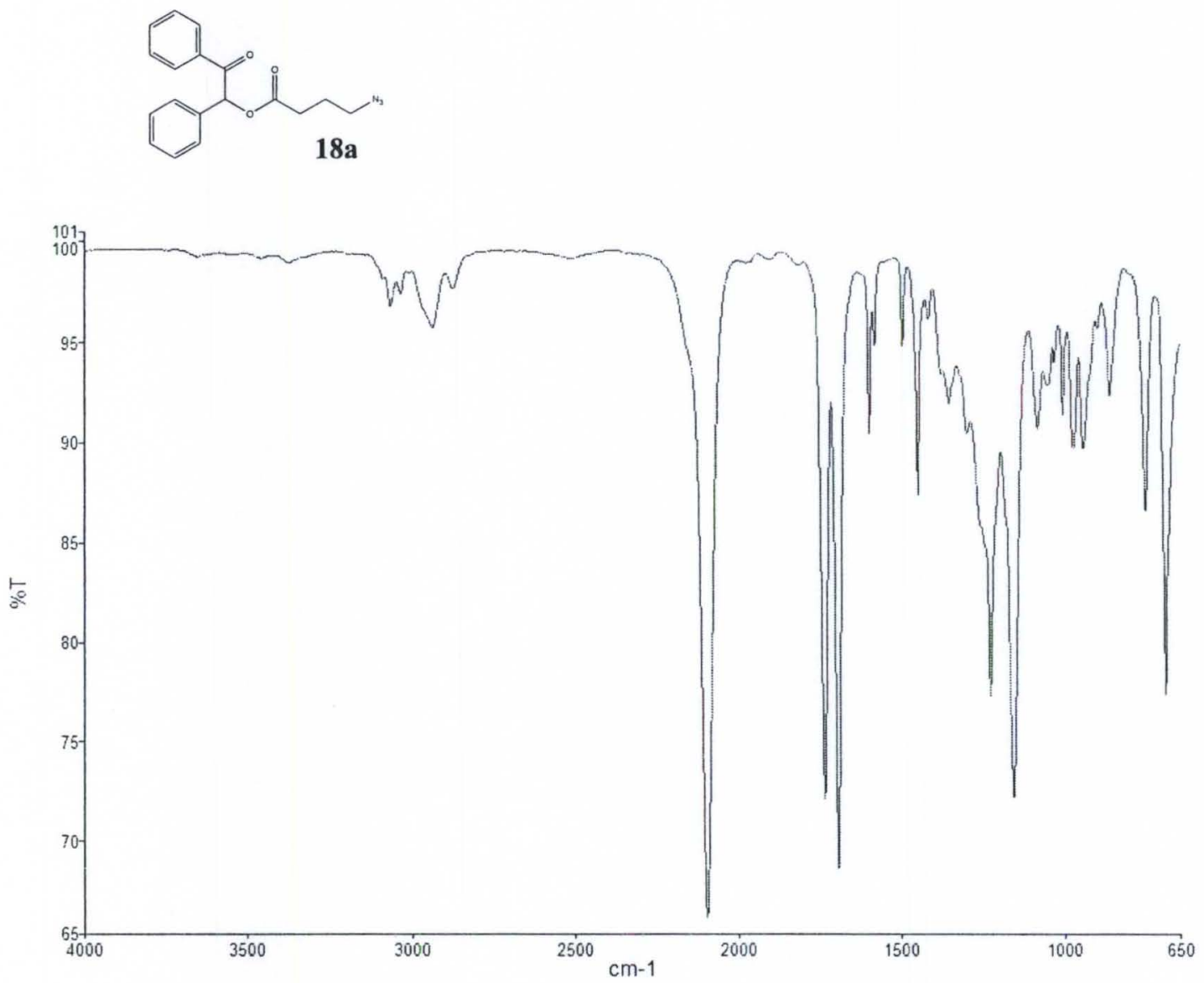

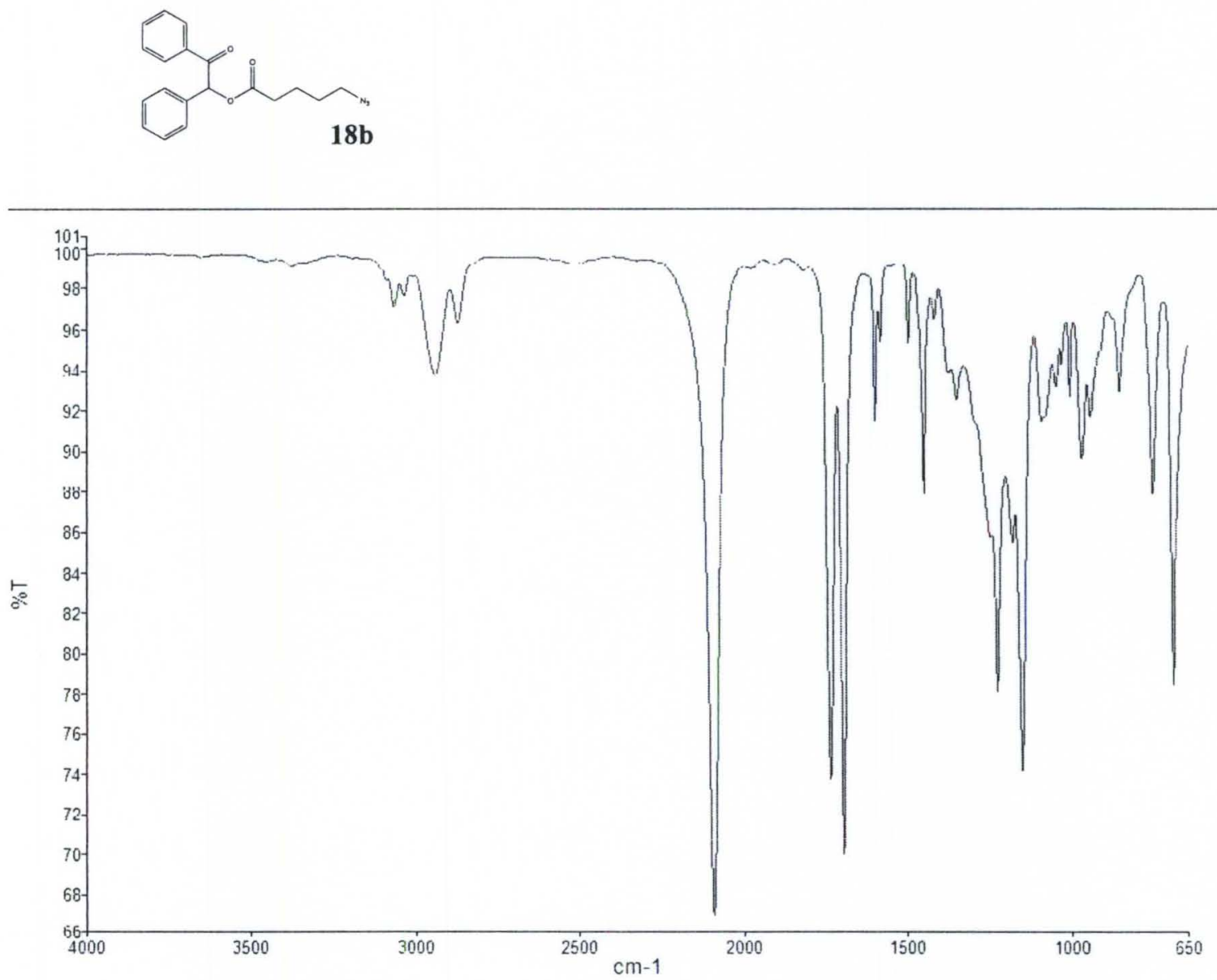

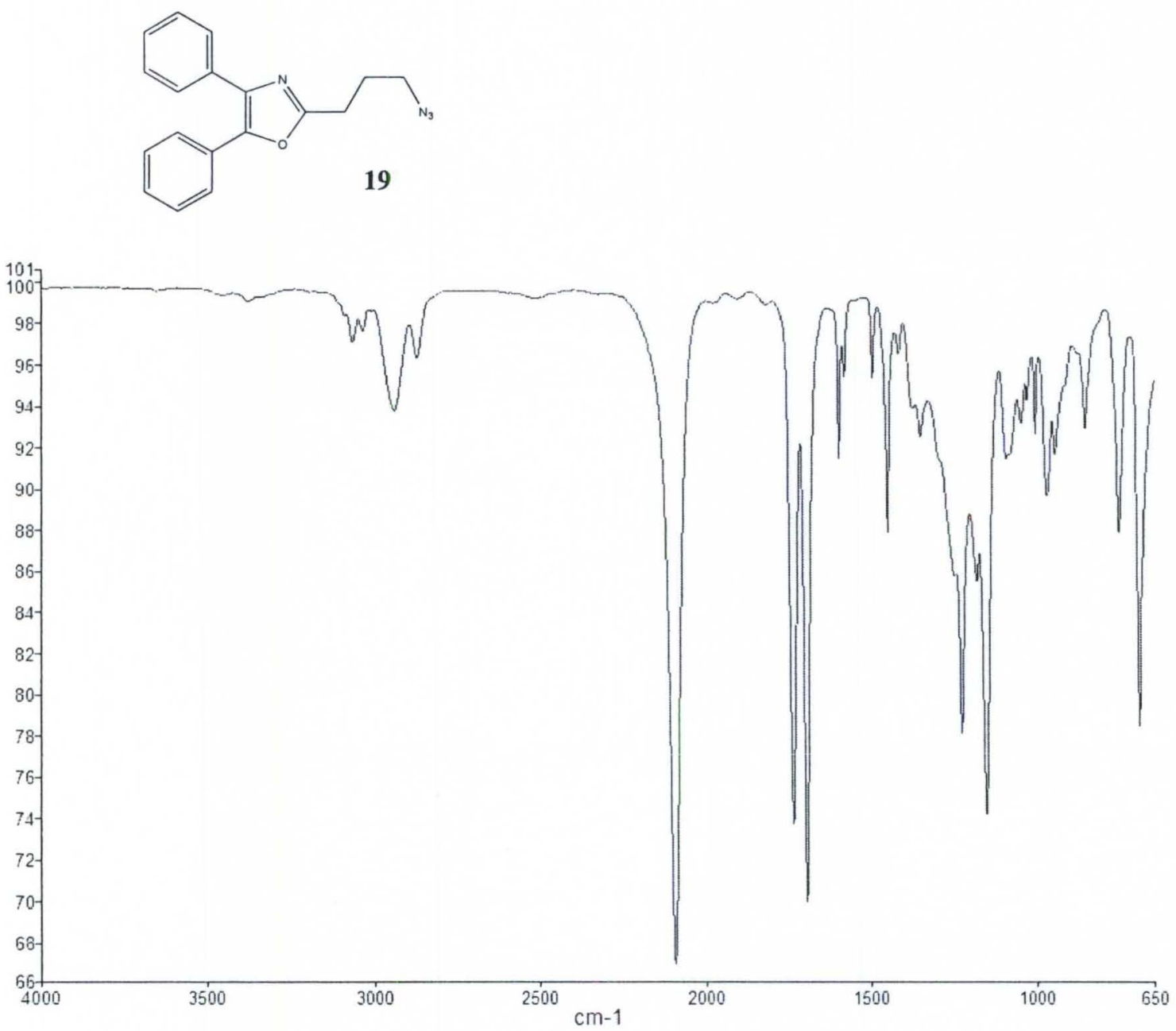

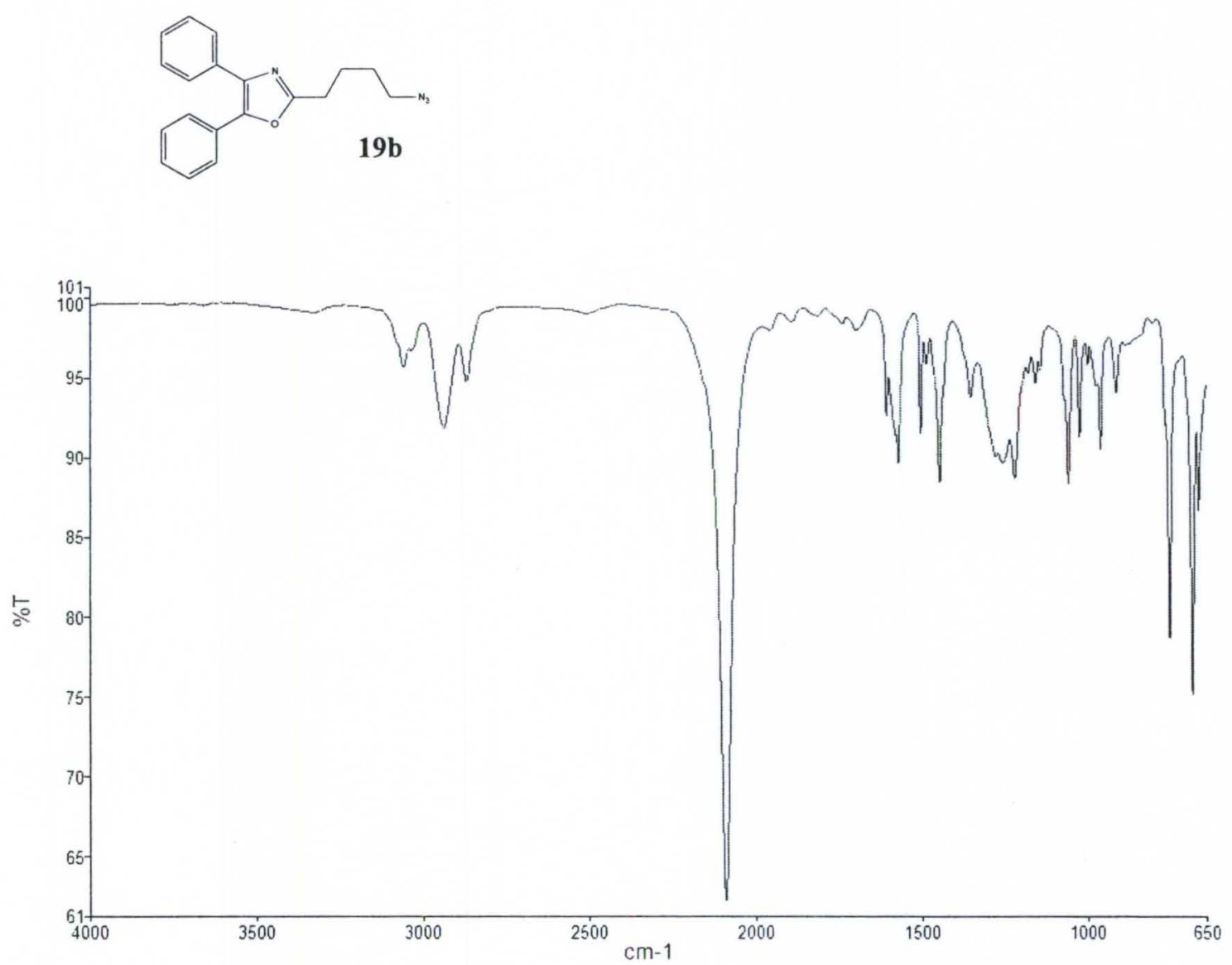

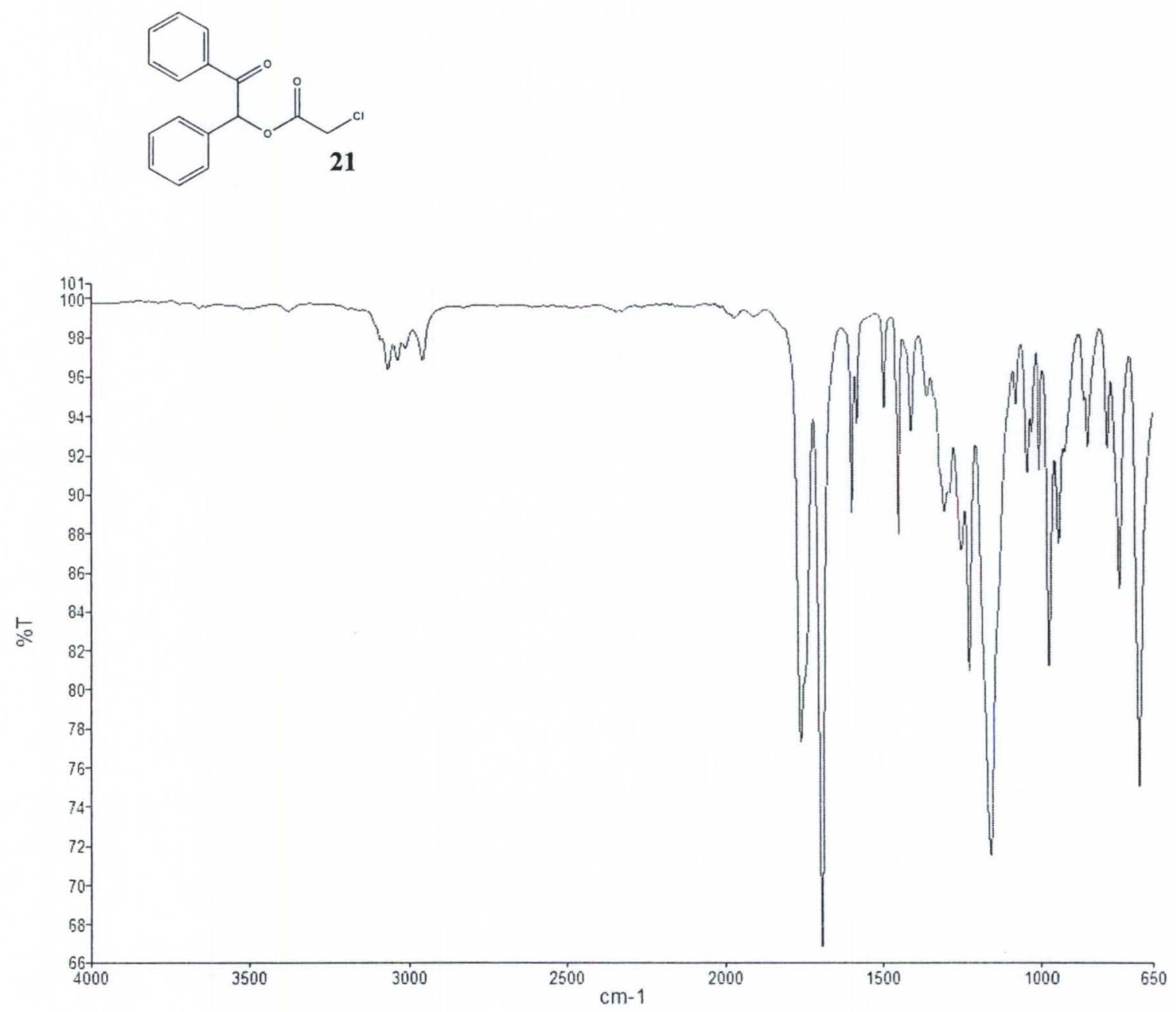

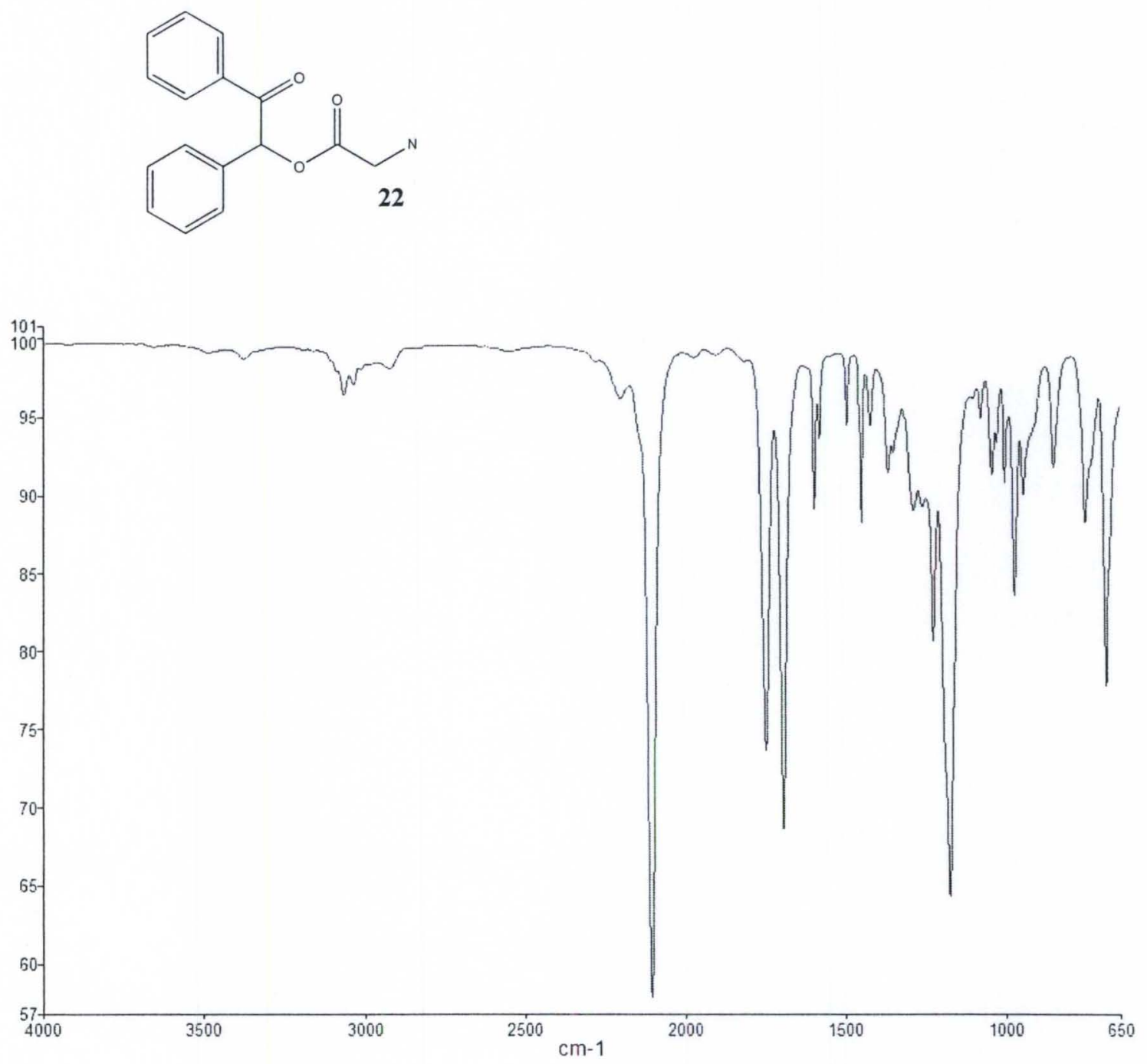

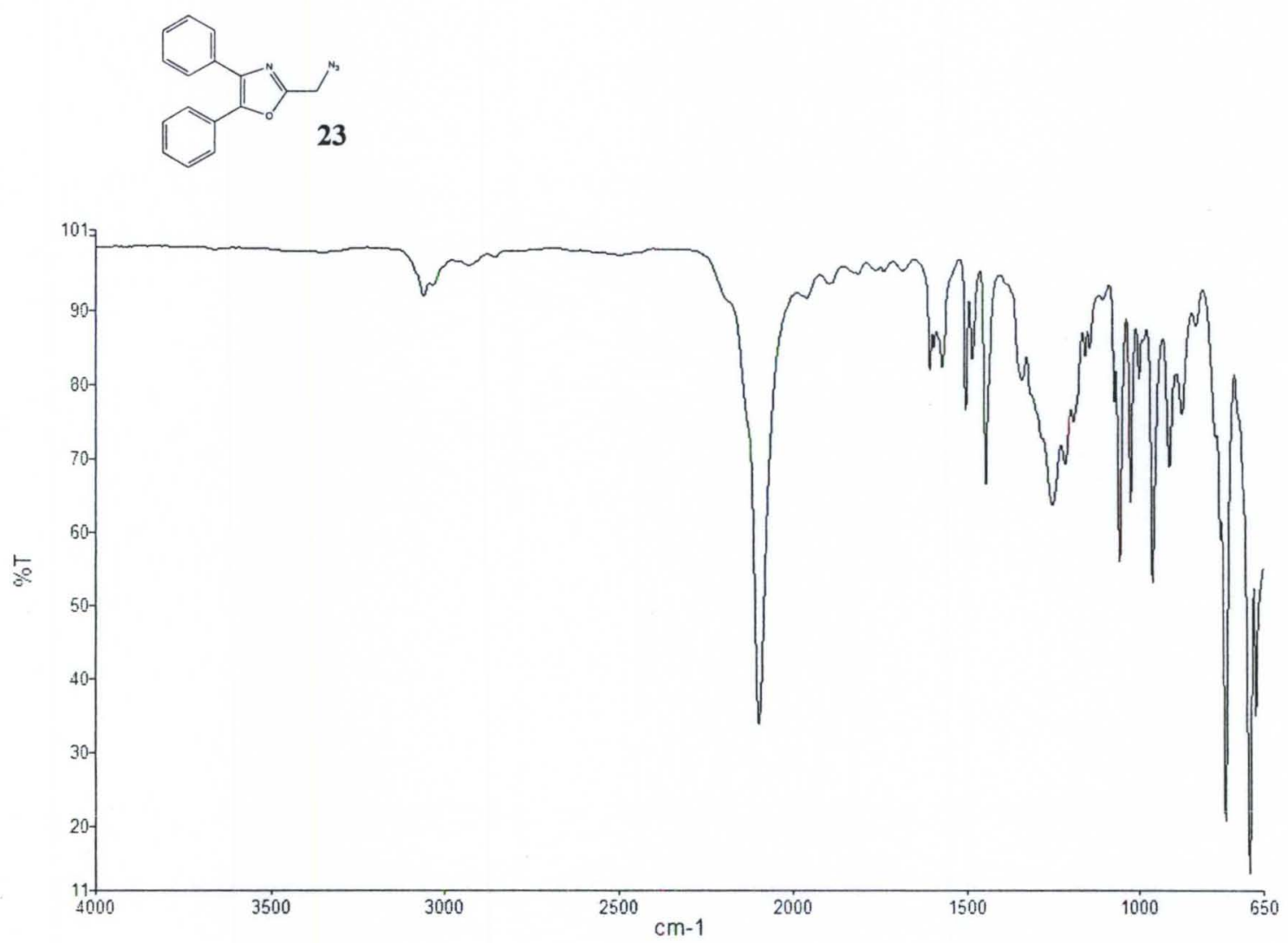

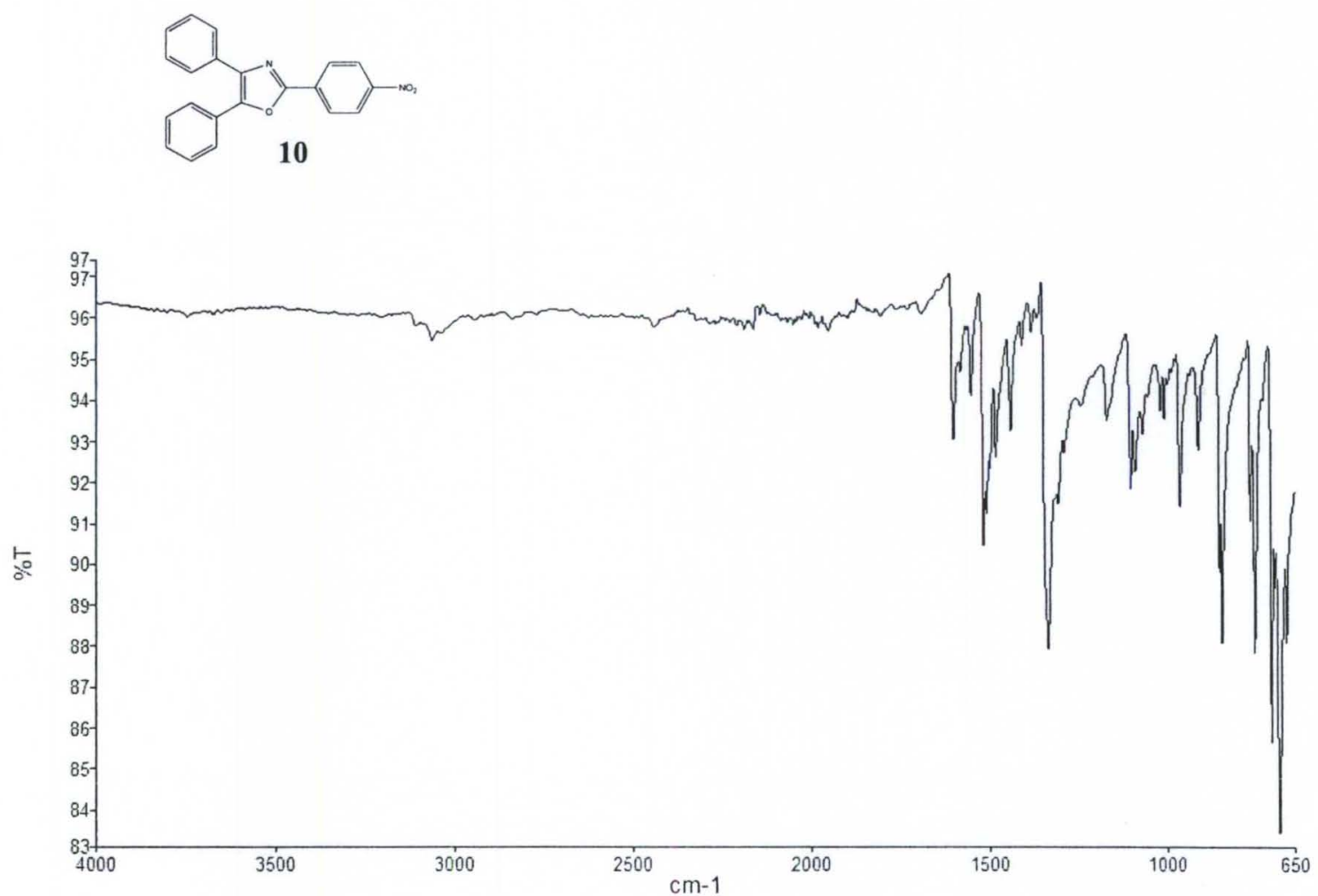


\section{CURRICULUM VITAE}

\section{CATHERINE MARIE LONER}

Permanent Address: 4225 Ruby Court $\cdot$ Jasper, Indiana $47546 \cdot$ (812) 661-7663

Cmlone01@louisville.edu

\begin{tabular}{|c|c|c|}
\hline DUCATION & $\begin{array}{l}\text { UNIVERSITY OF LOUISVILLE } \\
\text { SCHOOL OF DENTISTRY } \\
\text { Doctor of Dental Medicine } \\
\text { Overall GPA: N/A } \\
\text { UNIVERSITY OF LOUISVILLE } \\
\text { Masters in Oral Biology } \\
\text { Overall GPA: } 3.880 \\
\text { UNIVERSITY OF NOTRE DAME } \\
\text { Bachelor of Arts in Spanish } \\
\text { Major GPA: } 3.37 / 4.0 \text {, Overall GPA: } 3.30 / 4.0 \\
\text { FUNDACION JOSE ORTEGA Y GASSET } \\
\text { Notre Dame Summer Foreign Study } \\
\text { ST. MARY'S COLLEGE } \\
\text { Spanish } \\
\text { Overall GPA: } 3.84 / 4.0\end{array}$ & $\begin{array}{l}\text { Louisville, KY } \\
\text { August } 2010 \text { - Present } \\
\text { Notre Dame, IN } \\
\text { August } 2007 \text { - May } 2010 \\
\text { Toledo, Spain } \\
\text { 2008 Summer Semester } \\
\text { Notre Dame, IN } \\
\text { August } 2006 \text { - May } 2007\end{array}$ \\
\hline
\end{tabular}

AWARDS, HONORS, SCHOLARSHIPS

- Carl and Janet Edmundson Scholarship

2008

Mr. Carl R. Edmundson

- Verkamp Family Scholarship 2008

Mr. Gilbert D. Verkamp

- Holy Cross Scholarship 2008

University of Notre Dame
Dean's List

St. Mary's College

- Presidential Scholarship 2006

St. Mary's College

\section{SERVICE}

- St. Adalbert's Catholic School, Tutor 2008-2009

- Big Brothers and Big Sisters of St. Joseph County, Volunteer 2007-2010

- Residence Hall Government, Social Concerns Commissioner, 2008-2009

- University of Notre Dame Spring Break 2009 Service Trip to L'Arche community of

Washington D.C.,

Volunteer

- Special Olympics of St. Joseph County Late Night Olympics, Volunteer, 2007, 2008, and 2009 


\section{RESEARCH}

- Undergraduate Research at the University of Notre Dame/St. Mary's College June 2009 December 2009

- Medicinal Chemistry research on the synthesis of phosphatase inhibitor analogues with anti-cancer application potential.

- Graduate Research at the University of Louisville August 2010 - Present

- Dual Oral Biology and Medicinal Chemistry research project

- Thesis: "Click" Scaffolds for the Inhibition of Porphyromonas gingivalis and Streptococcus gordonii Biofilm Formation

- Project presented at the Fall 2011 ACS National Meeting and Exposition

- Project Presented at Fall 2011 Research Louisville

- University of Louisville Summer Research Program 2011

- Project presented at the Spring 2012 AADR Annual Meeting

- Project presented at Indiana University Regional Student Research Day 2012

- Project to be presented at Summer 2012 Gordon Research Conference

- Manuscript in progress for submission

\section{WORK HISTORY}

- UNIVERSITY OF LOUISVILLE

Louisville, $\mathrm{KY}$

Graduate Teaching Assistant (Organic Chemistry I Spring \& General Chemistry II)

- UNIVERSITY OF NOTRE DAME Sports Information Office, Student Worker

- JASPER PARK AND RECREATION Red Cross Certified Lifeguard and Swim Instructor

- BUFFALO WILD WINGS RESTAURANT Server

- BUFFALO WINGS AND RINGS Server

$2011 \& 2012$

Notre Dame, IN

2006-2010

Jasper, IN

Summers 2006-08

Mishawaka, IN

2009

Jasper, IN

2012 